\title{
Field Description and \\ Sampling of Coal Beds
}

GEOLOGICAL SURVEY BULLETIN 1111-B

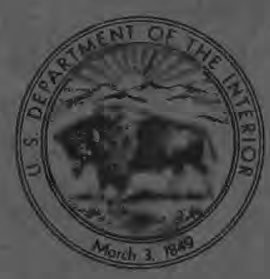


$(-x=1 / 8$

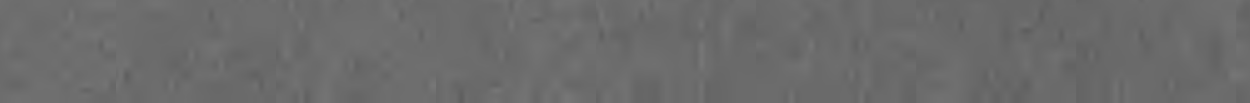
(2)

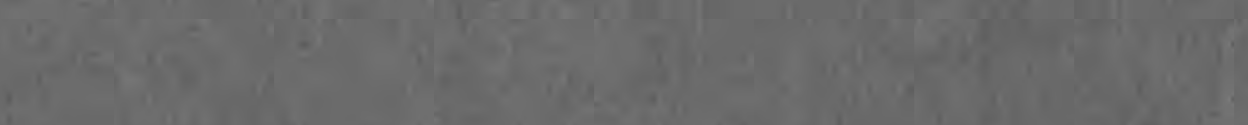

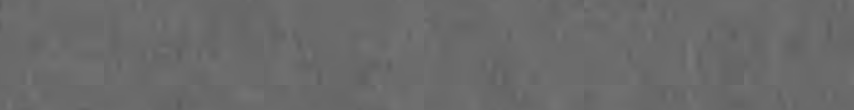

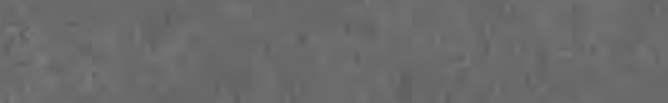
$\lim ^{2}+\frac{1}{2}$

$$
\begin{aligned}
& =x^{2}+56 \\
& \left.(1-7)^{3}\right) \\
& x^{2}+x^{2}=x^{3} \\
& 4
\end{aligned}
$$

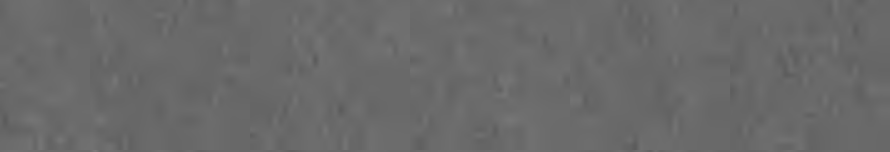

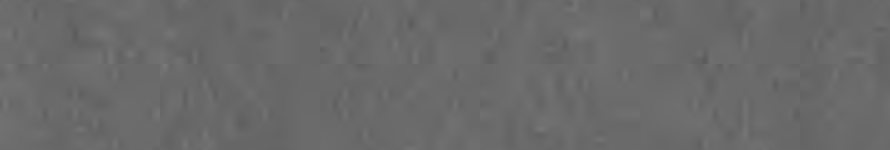

4.18

Ving

nits

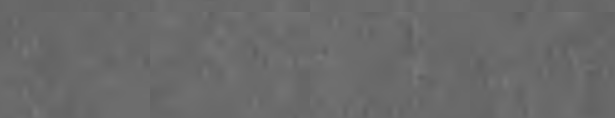

4.1. 40

$2 x^{2}+4$

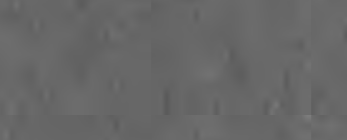
8

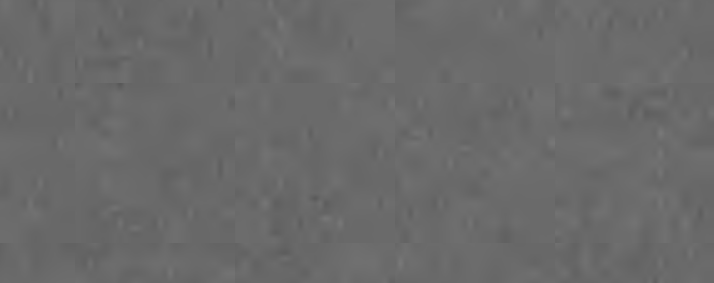

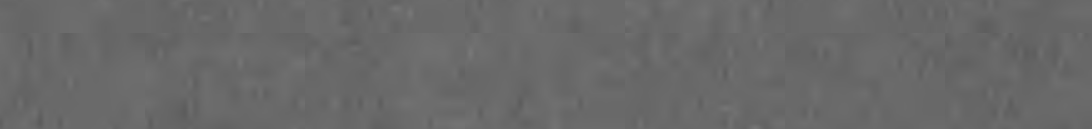

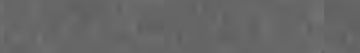

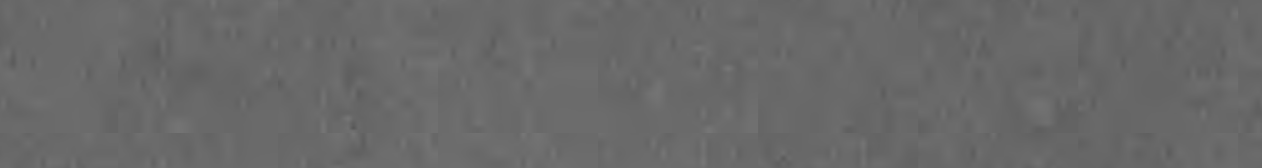

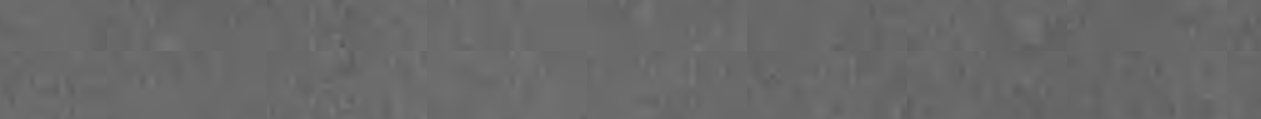

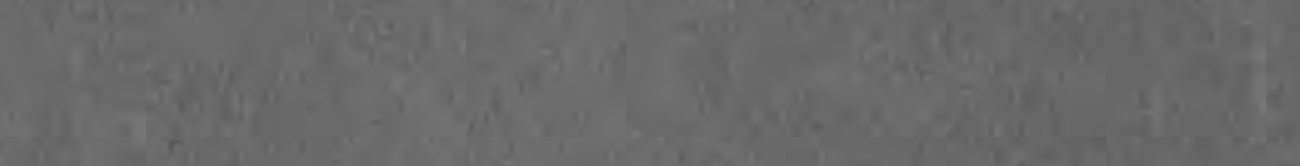

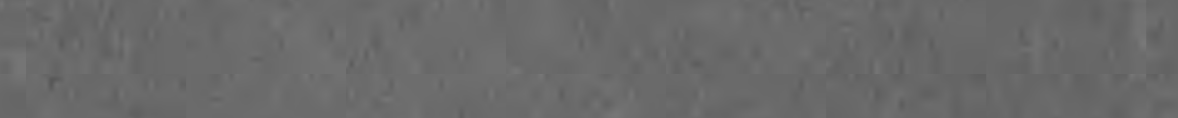

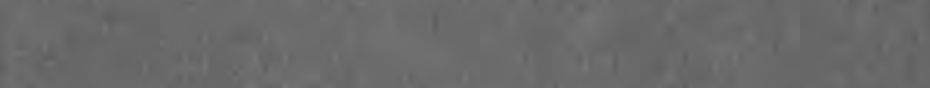

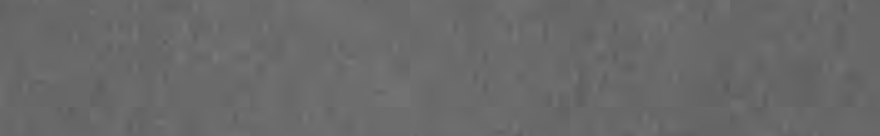

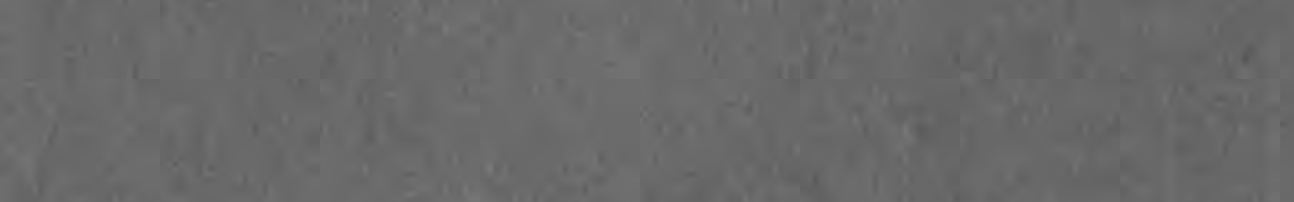

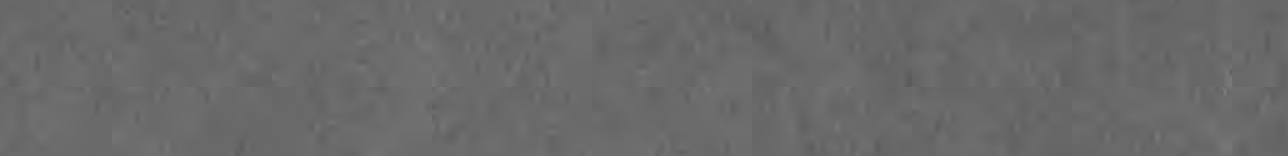

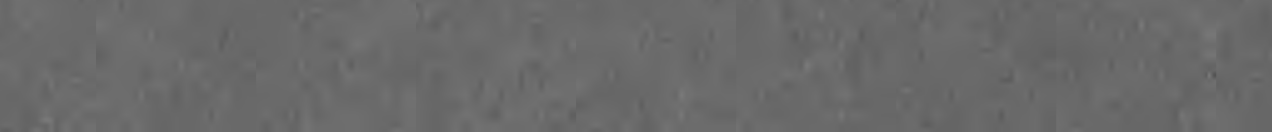

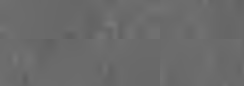

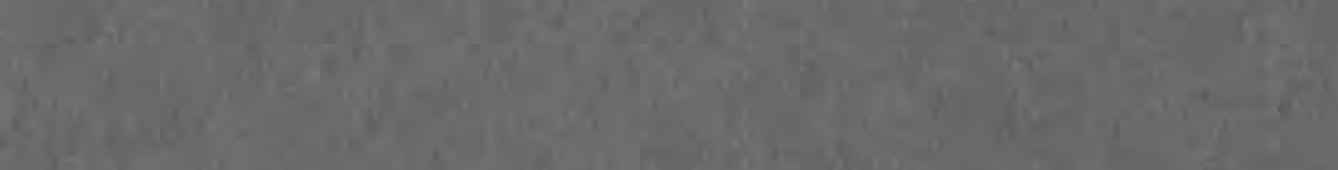

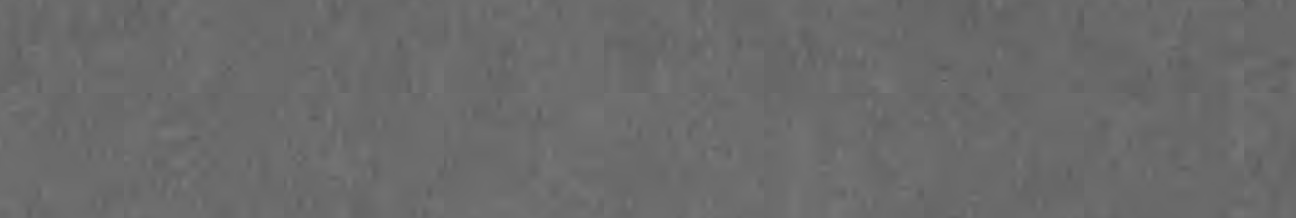




\section{Field Description and Sampling of Coal Beds}

By JAMES M. SCHOPF

CONTRIBUTIONS TO GENERAL GEOLOGY

GE O L O G I C A L S U R V E Y B U L L E T I N 1111-B

Information required in describing coal beds, with a discussion of sampling methods and applications for coal geology

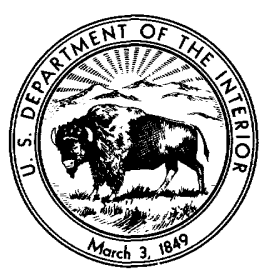


UNITED STATES DEPARTMENT OF THE INTERIOR

FRED A. SEATON, Secretary

GEOLOGIGAL SURVEY

Thomas B. Nolan, Director N/ Washington 25, D.C. 


\section{CONTENTS}

Abstract

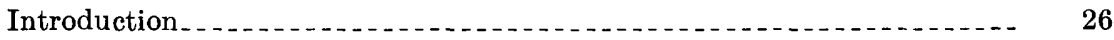

Deseriptive terms

Banded coal . .

Vitrain

Previtrain.

Fusain . .

Attrital coal . . .

Impure coal

Partings

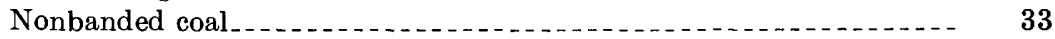

Bedding and banding in coal deposits _._. 35

Procedure for coal description

Conditions for observation

Preliminary procedure

Special equipment

Preparation of coal face.......... 37

Determination of coal layers

Methods of recording

Occurrences of vitrain

Occurrences of fusain

Occurrences of attrital coal _...

Spacing and extent of cleat.

Secondary and authigenic mineral occurrences........... 45

Effects of weathering

Preparation of field notes.... 47

Notes on coal sampling..... 49

Types of samples.... 49

Channel samples....... 50

Block and core samples._._.

Column samples._.

Summation of coal-bed information

Thickness characteristics... 56

Concentration of ingredients

Structural history and mineralization. 58

Use of analytic and coal-test data

Special equipment and supplies useful in field work on coal.

Core boxes and core shipment....... 62

Supplies for making coal core boxes. 63

Construction of core box. 63

Installing core in box. 63

Core-box data card

Shipment.

Illustrations

Literature cited. 66

Index 


\section{ILLUSTRATIONS}

[Plates 6-24 follow index. Plates 25-27 are in pocket]

Plate 6. Banded bituminous coal, Steubenville shaft, eastern Ohio

7. Banded bituminous coal, Meigs Creek bed near Cadiz, eastern Ohio

8. Banded bituminous coal, Bakerstown bed near Newburg, Preston County, W. Va.

Plate 9. Banded bituminous coal, Cumnock bed, Deep River coal field near Sanford, Chatham County, N.C.

10. Bituminous and subbituminous coal

11. Lignitic coal

12. Fusain; uncompressed woody lignite

13. Fusain

14. Fusain

15. Siliceous mineralization

16. Siliceous mineralization

17. High rank impure coal and carbonaceous shale

18. Coal balls and calcareous impurity

19. Pyritic impurity in coal and carbonaceous shale

20. Anthracite, natural coke, and high rank banded bituminous coal

21. Spore coal

22. Nonbanded coal and allied types of carbonaceous rocks

23. Weathering effects

24. Coal (?)

25. Thin bands concentration diagram

26. Medium bands concentration diagram

27. Thick bands concentration diagram

Figure 3. Construction and packing of single-row core box 


\title{
CONTRIBUTIONS TO GENERAL GEOLOGY
}

\section{FIELD DESCRIPTION AND SAMPLING OF GOAL BEDS}

\author{
By James M. Schopf
}

\begin{abstract}
Field procedures used in describing and sampling coal deposits should be uniform, and the acquired data should be as quantitative and complete as possible. Field data are the basis for laboratory studies and all conclusions drawn from fieldwork.
\end{abstract}

The lithologic layers (ingredients) whose alternation causes the banding observed in most coal beds should be identified in the field as vitrain (previtrain in lignite), fusain, attrital coal, impure coal, and partings. Other terms, no matter how nearly synonymous, should not be used in field descriptions. Vitrain bands generally have brilliant luster, vitreous appearance, conchoidal fracture and are closely cleated. Previtrain in lignite lacks these properties but is tougher and smoother textured than other ingredients. Fusain resembles charcoal, is soft and friable unless mineralized, is dull and occurs in chips or thin layers. Attrital coal is the matrix between the other ingredients and is intermediate between them but highly variable in luster, friability and cleat. It includes the streaks resembling vitrain and fusain that are thinner than half a millimeter. Impure coal and partings should be described fully by using standard geologic terms; local or common nondescriptive terms (for example, bone, rash) are inadequate. Notation of relative hardness is important.

Nonbanded coal is uncommon but may form entire beds or be bedded with banded coal. It is formed of sorted plant debris and is thus uniform in texture, compact, and massive. Its megascopic appearance is controlled only by particle size; its classification as boghead or cannel requires microscopy.

In the field a clean, unweathered coal face should be divided for descriptive purposes into units of uniform character. The thickness of the layers should be recorded in millimeters (one twenty-fifth of an inch), and the thickness of principal units and the overall thickness of the bed should be recorded in feet and inches. Recommended quantitative terms for both thickness and concentration of each lithologic type within each unit should be used in addition to descriptions of luster, texture, and fracture. The spacing and orientation of cleat (vertical joint planes), secondary mineralization, impure layers and partings, and roof and floor rock should be measured and described in standard geologic terms. Although field observations are necessarily made under man: different conditions, later comparisons and interpretations should be as uniform as possible. This requires that field notation of conditions of observation (favorable, generalized, or unfavorable) be made.

The type of coal sample taken depends on the laboratory determinations desired. Mixed samples (channel samples) representative of entire bed thickness 
are standard for ordinary chemical analyses and suitable for some microfossil studies. Individual block samples that together represent the entire bed are useful for nearly any type of chemical, petrologic, or plant fossil study, but a nonolithic column sample of the entire bed is superior. Every type of sample, including cores, must be vigorously guarded against moisture loss if the samples are to be used for microscopic study or for chemical analysis. Moisture is not an important consideration in samples obtained solely for microfossils. Cores should be handled as little as possible in the field. Directions for taking samples and for construction of suitable core boxes are given.

Trends of variation in the properties of coal beds that are measured in the field or in the laboratory are best presented by means of maps on which contours are shown for the particular property under consideration. Some of the properties are the thickness of the entire coal bed or correlative parts of it, the interval between coal beds, overburden thickness, concentration of vitrain or other petrologic type, spacing of cleat, secondary mineralization, any of the results of chemical analysis, carbon or other ratios.

\section{INTRODUCTION}

The coaly carbonaceous rocks include not only the commercial varieties of coal but also some rocks that can be classed as oil shale. All contain direct evidence of derivation from life of ancient plants. Some of the plant material is well preserved, and the plants themselves often prove to be bizarre and amazing. Many of the coaly types of rocks consist of residues of plant substances which have been degraded in varying degree by biological or chemical agencies. In every instance this variety among carbonaceous rocks is a source of information and a reflection on ancient life environments.

The chemical composition of the various coalified materials in place is still somewhat speculative, and coal petrologic studies in recent years have shown that the most precise clue to the composition of any heterogeneous coaly aggregate must be based, not only on the results of bulk analyses, but also on comparative physical evidence. This knowledge is important because these coaly materials are still the basic fuel for our increasingly industrial civilization.

Paradoxically, products derived from coal are often a great deal better understood than the nature of coal itself, but one relatively simple means of learning about the nature of coal and the variations in coaly deposits is by closer attention to visible megascopic features. Such information will have increasing importance as new mines must be opened. If possible, coal producers would like to prepare better coal to meet increased demand of the future, although new mines probably will be operating in poorer deposits. It may be feasible to improve the product obtained from some deposits; but, whether quality of commercial coal is improved or not, coal is a highly competitive commodity. The best available coal often must come from lessthan-ideal deposits. Much of the best coal formerly available has been used. Geologic information plays a greater part in suggesting 
which beds of less-than-ideal quality offer the most favorable future opportunity to produce coal that will meet necessary specifications. Information that can be provided from a geologist's megascopic examination of the coaly material will never be fully adequate by itself, but it can be used to direct attention to areas in which further detailed study and testing are most likely to be rewarding.

The accurate description and proper sampling of coal beds are important parts of the geologic study of coal. Sections of coal beds which are carefully measured and described and properly spaced and compared, are useful in establishing correlations between coal exposures, in predicting rariations in concealed parts of coal fields, and in appraising reserves of coal. The proper sampling of coal beds provides material for laboratory studies that supplement these objectives and aids in determining the manner in which the coal can be most advantageously used. Methods of sampling for chemical analyses have in the past been given the greatest consideration, and those needed for other geologic purposes have generally been neglected. Individual systems of coal description have been used with widely varying results. This report is intended to encourage more uniform procedures and, consequently, more uniform results in geologic studies of coal resources.

One of the major benefits to be attained from careful systematic study and sampling of a coal bed is knowledge of the manner and degree of lateral variation in the bed. Although this information is essential to the proper understanding of any coal bed, only rarely are the changes so striking as to be evident on casual inspection. For this reason, detailed exanination, measurement, and sampling of coal beds are necessary to reveal the significant features. Examples of some of these features are illustrated on the accompanying plates.

A field geologist must be discriminating in taking samples and in making field observations. Samples should be taken whenever analytic results may have a significant relation to field observations. Not every coal exposure can be described in significant terms, for weathering may alter the coal, and staining may obscure natural surface features. In many places effective coal study depends on timing, as coal is best observed when exposures are fresh. Coal deteriorates with exposure, although this is not necessarily true for other types of rocks. It is important to recognize the conditions under which a satisfactory megascopic description can be accomplished, as well as the limitations of materials sampled. Methods for indicating differences of opportunity for observation and sampling are described in the section "Conditions for observation," on page 36. Recognition of a great diversity of conditions for observing and sampling coal is necessary if the methods outlined here are to be used successfully by field geologists. 


\section{DESCRIPTIVE TERMS}

Although coal description, like any other type of description, is an art and, therefore, cannot be rigid, the systematic approach is strongly urged. A nonsystematic approach, characteristic of some published reports, commonly does not provide adequate information and is difficult to interpret. In present coal preparation plants, the comparative characteristics of attrital coal, impure varieties of coal, and partings have more significance.

Terminology is not the least of the problems involved in the description of coal, but terminology has been kept to a minimum in the present treatment. However, we have passed the stage where the undefined concepts of "bright coal" and "dull coal" seemed to suffice, and more modern terminology has been used. This terminology has been restricted to terms that can be used in presenting the results of megascopic examinations and is not complicated.

Complication enters when the same term is used according to different standards of definition. Diverse standards are most commonly applied in coal microscopy; so the author has tried to avoid usage that could conflict with terms employed for reporting microscopical aspects of coal studies. During the past several years an effort by the International Committee for Coal Petrology has been directed toward a standard terminology. This effort is bound to have beneficial results, although it is too early to say whether it will prove adequate for all analytic requirements. In any event, microscopic standards of definition apply to microscopic phases of laboratory study. Because of their inherent nature, they cannot apply to megascopic description of coal in the field.

The Glossary of Geology and Related Sciences, recently published by the American Geological Institute (Howell, 1957) is recommended as a source of information about the general usage of terms. Many terms relating to coal geology and to the anatomy of plants that enter into coal have been included in this glossary. It has more than ordinary value for those who lack familiarity with the extensive specialized literature in this field.

The most suitable petrologic terms for use in describing coal megascopically are employed herein. Brief explanations of these terms are given below.

Commercial varieties of coal may be divided into two groups, the banded or the nonbanded. The differences between the two groups are the result of different modes of accumulation. Sometimes both banded and nonbanded coals occur as separate benches of the same bed; these bed varieties are said to be mixed. The coal bed is taken as a unit for descriptive and classification purposes, regardless of whether it is banded, nonbanded, or mixed. 


\section{BANDED COAL}

Most commercial coal is banded, owing to alternations of two or more of the main coal ingredients, vitrain, fusain, and attrital coal.

\section{VITRAIN}

Vitrain is the ingredient in coal composing the shiny black bands that have brilliant luster, vitreous appearance, and conchoidal fracture. Vitrain usually is more closely cleated (jointed) than other coal material in the same bed. In bituminous ranks of coal vitrain is more friable than the associated coal of silky or granular texture and tends to break irregularly. For these reasons it is likely to be concentrated in the smaller sizes of commercial coal. Vitrain has been labeled on various illustrations. (See pls. 6, 7, 8, 10, 14, 17, $19,20$.

The properties of vitrain vary with its degree of metamorphism or rank, and it is notable that within the coking range, the coking properties of a coal are related to its vitrain content. Thus variations in the vitrain content between coal beds, or within individual coal beds, may be very important. This is particularly true for borderline coking coals. Handpicked samples of vitrain most nearly approximate the ideal concept of "pure coal" because they usually contain the least amount of mineral matter. Vitrain is more nearly uniform in purity than any other coal ingredient at any given mine or locality.

The term "vitrain" is here applied only to bands thicker than onehalf millimeter (one-fiftieth of an inch) ; shreds of vitrinized material less than one-half millimeter thick can be called microvitrain, but it is more practical for purposes of megascopic description to consider them as part of the attrital coal.

Vitrain bands, all elongate lenses, are derived from single, relatively large fragments of ancient plants. An unusually clear example of a vitrinized $\log$ is shown on plate 10, figure 3. Except for mineral matter on cleat (joint) faces, the ash in vitrain is largely derived from a remnant of the inherent ash of the original plants. Thin slabs of coalified bark, like that in the specimens illustrated on plate 6 and plate 10 (fig. 2), provide much vitrain in coal of Paleozoic age. Thick woody trunks, like that on plate 10 (fig. 3), are the chief source of vitrain in coals of Cretaceous and Tertiary ages. Differences in habit of the vitrain occurrences often are so marked that a general age assignment can be suggested after brief examination.

The term "anthraxylon" is sometimes used as a synonym for vitrain, but its use is not recommended for fieldwork. Its proper application is in the field of quantitative microscopy (Schopf, 1956b). 


\section{PRevitrain}

Previtrain constitutes dense woody lenses in lignite that are clearly equivalent to the vitrain in coal of higher rank. Previtrain usually is not distinguished by luster or cleat from ingredients associated with it, but it is tougher. Owing to its smoother texture, the "grain" of coalified woody material is often visible. Fracture surfaces of previtrain are not as rough or earthy as those of the associated attrital material in lignite. A fracture surface of a thick woody lignite layer from a core is shown on plate 11, figure 2, and somewhat thinner previtrain layers are shown on the slightly dried saw-cut surface of a core on plate 11, figure 1. The density of previtrain is caused by collapse of cellular tissues and elimination of open cell cavities. The specimen shown on plate 12, figure 2, is from the same district as those shown on plate 11 , but it was in a vertical position and not so compressed and, hence, appears more fibrous. In lignite, not even previtrain has swelling or coking qualities.

\section{FUSAIN}

Fusain, in the megascopic sense, is the ingredient in coal that resembles charcoal. It occurs as dull black chips, lenses, or thin layers, and is referred to in many older reports as mineral charcoal. Fusain is soft and friable except where mineralized and typically has a minute fibrous and porous structure (pl. 13, fig. 1). It is not cleated. Bands and chips of fusain distributed parallel to the bedding commonly form planes of weakness in coal of high-volatile bituminous rank. Fusain is the "dirty" ingredient of coal and often composes a large part of the dust removed from bituminous coal by dedusting processes. The most characteristic occurrence of fusain is shown on a saw-cut surface, normal to the banding, on plate 14. Less common types of occurrence are shown on plate 12 (fig. 1), plate 13, and on plate 15 (figs. 1 and 2).

Fusain is always noncoking, and analyses of handpicked fusain normally show relatively high calorific values and fixed carbon. As it yields but little volatile matter, it burns smokelessly. Its natural lack of cleat, even in highly cleated low-volatile bituminous coal, permits sizable fusain lenses and bands in low-volatile coal to bind together many of the larger lumps produced in mining. Coal of lowvolatile bituminous rank normally breaks down into fine sizes because of intensive cleat in the other ingredients. Owing to its porous texture, fusain is most susceptible to secondary mineralization (pl. 15, figs. 1 and 2); consequently, abundant fusain may indicate high ash.

Fusain is most evident in bituminous coal, but it may be abundant in subbituminous coal or even in lignite. Fusain also is present and physically distinguished in anthracite (pl. 17, fig. 2), but in anthracite the chemical properties of fusain resemble those of other ingre- 
dients. Although fusain may be formed from any type of plant remains ( $p l .15$, fig. 1), the cell walls of fibrous tissues usually are responsible for its characteristic minute fibrous structure, as shown on plate 13, figures 1 and 2. Its porosity is derived directly from the empty cellular cavities of the tissues of the griginal plants.

Fusain fragments of all sizes occur in coal, but only chips and aggregations more than one-half millimeter (one-fifth of an inch) thick and $1 \mathrm{~cm}$ (three-eighths of an inch) long are classed as megascopic fusain. Smaller fragments are considered a part of the attrital coal for purposes of megascopic description.

\section{ATTRITAL COAL}

Attrital coal constitutes the microfragmental matrix that occupies the interstices between other coal ingredients. Its luster ranges from bright to dull, but it never is as brilliant as vitrain nor as dull as fusain. Somewhat in accordance with its luster, it ranges from moderately friable and moderately to highly cleated, to tough and almost massive. The more massive varieties may show an intergradation with varieties of nonbanded coal. Several types of attrital coal are shown on plates 6,9 , and 10 (fig. 2), and on plates 11, 14, 17, 19, and 22 .

Attrital coal is derived from all kinds of plant debris deposited in a finely divided, but usually unsorted, condition. Consequently its chemical and physical properties vary greatly, depending on the dominant kinds and concentrations of the original organic particles and the different responses of these particles to coalification. The chemical differences between attrital coals of differing organic composition decrease with increase in rank, but physical differences in the attrital ingredients can be demonstrated at least microscopically, even in anthracite.

Bright luster attrital coal, like that shown on plates 7 and 9, and on plate 19, figure 1 , is derived chiefly from lignocellulosic plant debris. In the proper range of rank, it may be strongly coking like the associated vitrain and may compare rather closely with it in its coking properties. Fixed carbon and volatile matter of bright luster attrital coal also tend to be similar to that of the vitrain associated with it, but dull luster attrital coal shows a more variable relation.

Attrital coal of dull luster, like the top layer of plate 6 or the specimens shown on plate 21, usually does not have good coking properties because the several qualities that cause dull luster also are to a somewhat greater or lesser degree detrimental to coking. Hardly any other generalization about this coal is possible, however, because dull luster and toughness may be due to several very different causes. As a rule, auxiliary information based on microscopic study is essen- 
tial for correct interpretation of the different kinds of dull attrital coal seen in the field.

The terms "durain" and "splint" are sometimes applied to dull luster attrital coal, and "clarain" to bright luster attrital coal. As usage of these terms is not standardized, and microscopic data seem essential for any standardization that may be proposed, they are not recommended for field use.

\section{IMPURE COAL}

Impurity in coal is defined by the economics of use, but the economic setting is likely to be established after, rather than before, geologists have studied a deposit. If a minimum ash or mineral matter value for coal regarded as impure or noncommercial is not already established from commercial practice in a district, an ash content of about 25 percent or mineral content of about 30 percent (both gravimetric) may be assumed to represent the minimum quantity of impurity required for a sample to be classed as impure coal. Although in extreme cases it is possible to estimate the density of a specimen in the field, the volume occupied by mineral matter has greater influence on appearance. If the mineral content in a coal sample is entirely pyrite (specific gravity about 5.0), 30 percent by weight will equal about 10 percent by volume; if the mineral is entirely clay (specific gravity about 2.3), 30 percent by weight is equal to about 22 percent by volume. Ash values usually (but not invariably) are lower than corresponding mineral matter values, owing to loss of hydration moisture from clay and decomposition of carbonates and sulfides with gaseous products. To some extent these losses are counterbalanced by the oxygen combined with elements in the incinerated residue. The author (Schopf, 1956a) has proposed that coal, as such, be defined arbitrarily as having less than 50 percent mineral matter by weight and more than 70 percent carbonaceous matter by volume. These values suggest only the maximum impurity that may be included in the category of impure coal. Rocks having a greater amount of impurity are not coal, but they may be described as coaly clay or coaly or bony shale, to call attention to any apparent resemblance to coal. Commercial coal usually has less than 25 percent ash, or roughly 30 percent by weight of mineral matter.

Under field conditions it is often difficult to recognize the kinds and degrees of impurity in coal; and as a result, no consistent standards apply to common terms, such as "bone," "jack," "billy coal," "dirty coal," "rash," and others that are used. The hard tough varieties of impure coal or coaly shale, like that shown on plate 17 (fig. 3), or plate 21 (figs. 1, 2, and 3), usually are called bone. The term "dirty coal" has been applied diversely to friable pulverized streaks, 
to soft dark clay, or even to lenses of soft fusain in coal beds. The common terms may be used according to local custom, but the same term may have different meaning to different people; so it is essential to describe the material in detail. Whether an impure layer is hard or soft is important as this may suggest whether the impurity will segregate in mining or slake during washing. Certain types of impure layers may be so abundant that they require specific recognition, but the means of differentiation may be difficult to express solely on the basis of what is visible in the field. Specimens from such layers should be submitted for laboratory study. Microscopic study will usually reveal a few significant variables that can be subsequently interpreted megascopically, even though the value of such an interpretation may be restricted to a particular coal bed within one mining district.

\section{PARTINGS}

Partings (or "binders") are easily identifiable discrete bands of mineral sediments interbedded with coal. Shale or clay partings are the most common, but sandy or even calcareous partings may be observed. Indefinite layers of impure or bony coal, like that shown on plate 9 , usually are not considered as partings, even, though they may merge with bony or coaly shale.

Ordinary geologic terms should be used in describing partings. Some partings are persistent and have rather distinctive characteristics that are useful for purposes of bed identification. Such partings may have local names. The composition, color, and physical characteristics of all partings should be described. It is usually unsatisfactory to refer to them by only their local name.

\section{NONBANDED COAL}

Nonbanded coal is much less common than banded coal. It may be interbedded with common banded coal, or it may compose the entire bed. Nonbanded coal is completely attrital in origin, having been derived almost entirely from water-transported and size-sorted plant debris. In this respect it differs from banded coal, which is formed from unsorted plant debris of more heterogeneous sizes. For this reason, nonbanded coal is notably uniform in texture, compact, and massive, usually has widely spaced joints, and breaks with a broadly conchoidal fracture. This condition is shown to some extent by the nonbanded specimen on plate 22 , figure 1, although almost featureless surfaces are more common. Surfaces may be minutely rough, greasy or satiny, or visibly smooth in texture, and they may show dull to moderately bright luster. Rarely nonbanded coal may include a large erratic plant fragment transformed to vitrain.

Nonbanded coal is generally very heterogeneous in composition, depending on the concentration of different kinds of plant products. 
Chemical analyses of nonbanded coals are usually variable for this reason. Although they are undoubtedly affected by normal metamorphic alteration, their unusual composition makes it impossible to apply the normal criteria for determining rank. In nonbanded coal, microscopic particles, derived from fragments of plant cell walls of lignocellulosic composition, various plant secretions, waxes, gums, resins, tannins, spore coats, and cuticular fragments, may be deposited together. When they have been compacted, all the diverse kinds of minute particles form a compact massive-textured coal. Massive megascopic appearance thus is almost entirely related to the microscopic size of the particles composing the original peat and not to the chemical composition of any of the kinds of particles. Emphasis has been placed on differences between chemical analyses of nonbanded and banded coal because some nonbanded coal yields an exceptionally large amount of volatile matter; commonly such coal is essentially nonswelling. However, other nonbanded coals (usually those with brighter luster) have swelling and coking properties and less distinctive chemical analyses. In general, chemical and utilization properties of the many varieties of nonbanded coal do not coincide with the mode of aggregation or with features ordinarily visible in the field. It is not possible to predict what the composition is or what an analysis of nonbanded coal will be by megascopic inspection alone.

In the past, nonbanded coals usually have been called either cannel or boghead, oftentimes for inadequate reasons according to our present knowledge of these coals. Microscopic examination is necessary for consistent differentiation of the kinds of nonbanded coal. The differences depend on the essential nature of the aggregate; detailed direct microscopic observation is the only method that can be relied on to discriminate according to these differences. The varieties of nonbanded coal cannot be directly identified in the field.

The nonbanded coals are usually composed principally of plant particles too small to be identified even in the common botanical terms. In many cannel coals, only spore coats can be morphologically identified with assurance among the various other components. Spore coats rarely account for as much as 10 percent of the actual bulk of a deposit. They stand out conspicuously in thin section, however, and their contrast with the variously assorted and morphologically unidentifiable groundmass has given rise to the erroneous conclusion that cannel coals are necessarily "spore coals." The more abundant groundmass can be readily reported in terms used regularly in the micropetrography of coal, but surprisingly few systematic efforts to do so have been attempted. A considerable confusion in the literature has been the result. 
Characteristics of nonbanded coal are shared to a considerable degree by the various types of oil shale, three of which are illustrated for comparison in figures $3-6$ or plate 22 . Oil shale is often distinguished by higher ash content and usually by more conspicuous evidence of bedding. Some types of nonbanded coal may be classed as oil shale if only distillation quality, rather than microscopic composition, mineral content, or a normal coal analysis, is considered.

Boghead is a variety of nonbanded coal characterized by the presence of cutinous or waxy envelopes of a unique type of colonial alga (Botryococcus brauni Kuetzing) which evidently has very high volatile content and other chemical peculiarities. Algal remains commonly make up 80 to 90 percent of selected strata of boghead, but ordinarily the nonwaxy matrix predominates within a deposit and algal bodies are dispersed much as are the spore coats of cannel coal. Thus it is not difficult to understand why the chemical properties of distinctly different varieties of nonbanded coal have been found to overlap. Boghead coal is most frequently confused with oil shale owing to the large amount of volatile matter that results from thermal decomposition of the algal remains, but spore coats in an exceptionally high concentration may behave similarly.

The classification of a nonbanded coal as boghead or cannel depends chiefly on whether algal remains, or spore coats and other kinds of coalified plant particles are present in significant numbers. Since this is not determinable without use of special facilities, only the simple designation "nonbanded coal" should be used in field notes. Supplemental information about texture, luster, and surface features that can be reliably reported under field conditions should be added, because they can assume added significance when supplemented by results of microscopic study of the deposit. A laboratory report on the microcomposition of nonbanded coal and rocks of similar character should be requested if classification is needed to suggest special utilization possibilities.

\section{BEDDING AND BANDING IN COAL DEPOSITS}

The layered appearance of banded coal is attributable more directly to diagenetic compaction of large plant fragments that grew near their present place of occurrence than to sedimentary deposition. True bedding features, associated with roof and floor, partings, and types of sedimentary impurity, are usually invisible within the coal itself. Banded coal like woody and fibrous peat is an obscurely bedded deposit. Therefore, in describing banded coal, the term "banding plane" is commonly more appropriate than "bedding plane." Nonbanded coals represent a type of transported organic sediment, more liable to be visibly laminated and fissile as a result 
of bedding in deposition. Even so, bedding in nonbanded coals is commonly obscure even when the coal is fissile. Extremely uniform bedding in a similar type of highly carbonaceous deposit is well illustrated by the Chattanooga shale ( $p l .22$, fig. 6), but these beds differ greatly from the bands in banded coal, such as those shown on plate 6 .

\section{PROCEDURE FOR COAL DESCRIPTION}

\section{CONDITIONS FOR OBSERVATION}

Coal is a dark rock that generally presents low tonal contrast and is rarely exposed in the field under conditions suitable for observation. Even coal at fresh exposures usually is more or less coated with small coal particles and relatively fine dust. Consequently, in order to observe coal effectively, more than casual attention must be given to preparing clean surfaces and to arranging for proper illumination. The amount of visible detail is related directly to the light reflected from thoroughly cleaned surfaces.

Relatively well exposed outcrops may show little of the true nature of the coal because of changes due to weathering. Weathering causes luster to be diminished and, on occasion, clay films or iron stains may be introduced deep within the bed. The fresh exposures in mines are more easily prepared for effective observation unless the coal face is wet. Strip mines or shallow adits, where dry, clean fresh surfaces can be exposed and artificial illumination is not required, ordinarily will provide the best opportunity for field observation of the megascopic features of coal beds.

It is virtually impossible to describe coal accurately from the outer surfaces of diamond-drill cores, but good information can often be obtained after carefully splitting the cores. Plate 11, figures 1-3, shows sawed, split, and external surfaces of a lignite core. The specimen of natural coke shown on plate 20 , figures 2 and 3 , also illustrates the difference between the outer and internal appearance of core specimens. The description and sampling of drill cores can best be carried out after the cores have been taken to the laboratory.

It is important to indicate the conditions of observation as a preliminary to the actual field description of a coal bed. Field descriptions must be interpreted and compared in order to be useful. In order to compare field descriptions, it is essential that the conditions of observation also be compared. Differing conditions inevitably cause differences in description which must be considered in evaluating information about the coal. This information also is of importance in evaluating analyses of coal samples. 
A notation as to conditions for observation should, therefore, always be entered in field notes. Many factors can adversely affect the opportunity for field description, and generally a brief comment in this regard will serve to answer many questions later. One means of indicating observational conditions is suggested by the following definitions :

1. Conditions favorable to clear observation (good): Clean coal surfaces; favorable lighting, either natural or artificial.

2. Conditions suited only for generalized observation (poor) : Major features of coal lithology visible, partings and bench thicknesses reliable; however, fine banding and detailed surface structure only partly determinable.

3. Conditions unfavorable for observation (obscure): Nature of coal obscure, some lithologic features probably overlooked because of poor opportunity for study (badly weathered outcrops, only outer surfaces seen on coal cores, inadequate lighting or some other cause). Only qualitative data should be recorded under these conditions.

It is sometimes possible to supplement a poor opportunity for field study by means of specimens, carefully taken and labeled as to position in the bed. Descriptions prepared from such specimens after exposing clean surfaces, either in the field office or laboratory, will usually supply necessary megascopic information. If coal is too weathered to permit good specimens to be taken, this fact should be noted.

\section{PRELIMINARY PROCEDURE}

\section{SPECIAL EQUIPMENT}

Items that may be needed for work incidental to obtaining an adequate coal sample or description are discussed and listed on page 60. Requirements differ a great deal; the needed items depend on the conditions at the coal exposure. The coal geologist should try to anticipate what equipment may be needed to serve any particular job since it is impractical and unnecessary to have all kinds of equipment available on every occasion.

\section{PREPaRation OF COAL FACE}

The coal face at the point selected for observation must be trimmed to a surface approximately normal to the floor and roof, and dust and loose coal or dirt must be brushed from the immediate area. If there is a reasonable possibility of obtaining a good description (see p. 36) from the immediate area, a favorable exposure can be prepared for measuring without a great deal of preliminary work. Some work is always necessary, however; so it is very important to have proper equipment at hand. 
The zero end of a steel tape should be solidly fixed at the top of the bed. If a loop of wire is fixed at the end of the tape, it may be used to attach the tape to one of the coal chisels, a hammer, or a small spike driven into the roof rock near the contact with the coal. Fixing the end of the tape immovably at the contact not only eliminates errors due to slipping but also avoids the fatigue of holding the tape by hand and generally saves time.

\section{DETERMINATION OF COAL LAYERS}

After the entire thickness of the coal bed has been cleaned and prepared for measuring, the geologist should next examine the face carefully to determine the location and extent of the layers into which the bed can logically be divided. For example, the block of coal illustrated on plate 6 includes one distinct central layer and parts of two others. The layers should have, as far as possible, lithologic distinctness and lateral continuity. Adjacent layers may be distinguished chiefly by differences in thickness and spacing of vitrain bands, by small differences in the luster of attrital coal, by occurrences of dispersed fusain fragments, by impurities of various types, by diversity of cleat spacings, or by other minor differences. Thin clay partings that are not obviously local are best regarded as thin layers; thick bands of fusain may also be considered layers. In some places a layer might be composed of several thin partings together with intervening coal. Boundaries of the layers should be as definite as possible and should be distinguished and described with enough care to enable one to test fully the possibilities of layer persistence. Where there is no sharp contact between differing lithologic layers, it may be practical to mark two points and regard the intervening coal as a transition zone.

In thick coal beds of seeming uniformity, such as some thick lignite deposits, it may be advisable to introduce arbitrary layer divisions for descriptive purposes. The use of such divisions is recommended if the thickness of a layer exceeds 2 feet because it is difficult to scan a thicker layer very carefully or to make a direct visual comparison of all its parts. It is usually practicable to use a recognizable marker, such as the base or top of a vitrain or previtrain band, as the boundary of a layer.

After the layer boundaries have been determined-and this should be done only after careful general inspection-they should be marked, using wax pencil, a piece of adhesive tape, or any other practicable method, along the vertical line of the tape. The process of actual description can then be started. Under favorable conditions and after one is accustomed to the routine, these preliminaries can usually be completed in a few minutes. 


\section{METHODS OF RECORDINC}

After the boundaries of the layers have been marked, a skeleton log, showing the layers with their boundary measurements from the zero point at the top of the coal bed, should be prepared in the field notebook. Usually a semidiagrammatic representation is easiest to prepare and least liable to misinterpretation. The boundaries of layers can be indicated by a single number-the number of millimeters from the top of the bed. It will be :ound convenient and rapid to set down these measurements in spaced sequence at the left of the notebook page; a little foresight with regard to the elements of a proper description for the different layers will enable the note taker to leave adequate space between the dif'erent layer boundary measurements so that all descriptive data can ke intercalated in their proper relative positions.

Measurements of the layers should be recorded in millimeters rather than in inches or in decimals of feet, largely because of the advantage of working with whole numbers. A. millimeter is a small enough unit (approximately one twenty-fifth of an inch) that it makes possible greater relative accuracy. It is preferable to use a tape graduated in both millimeters and inches because equivalent measurements can then be converted by read ng directly from the tape. Such tapes are available from leading American manufacturers. Thickness of principal units and overall thickness of the bed should be recorded in feet and inches.

\section{OCCURRENCES OF VITRA] N}

Many of the layers in a coal bed will be found on close inspection to be composed of a simple alternation of vitrain and attrital coal, as the banding of coal is primarily (though not exclusively) a function of the occurrence of vitrain. As a convenience in note taking, the term "banded," unless otherwise specified, may be taken to refer only to the banding produced by vitrain. To avoid confusion by this practice, any band that consists of any other material must, of course, be specifically identified in its description.

In describing vitrain the important features are thickness of bands and concentration of these bands. Thickness and concentration of vitrain may best be described by consistent vsage of the following designations :

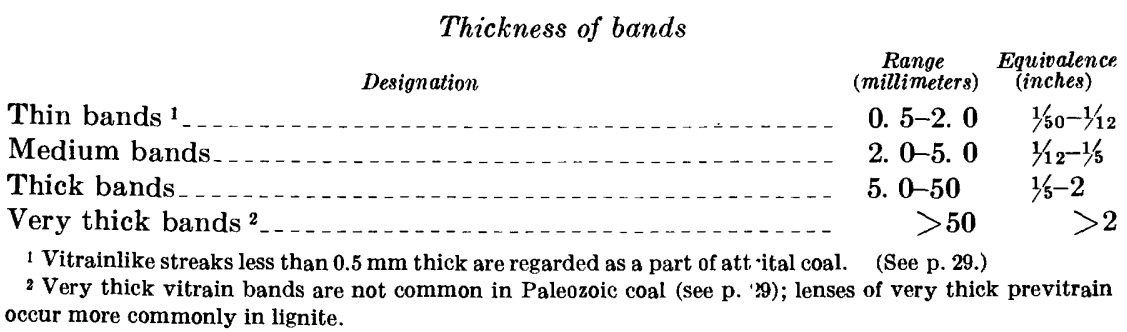


Concentration of bands

Designation
Sparse
Moderate
Abundant
Dominant

The concentration diagrams, plates $25-27$, have been prepared as visual aids in estimating the amount of vitrain in layers of coal. On these diagrams the black bars correspond to certain arbitrary thicknesses of thin, medium, and thick vitrain bands. The bars are distributed on white backgrounds so that they occupy 15, 30, and 60 percent of the total space. These are the threshold values between concentration classes as defined above. Thus by comparison with the diagrams, one may judge more easily which designation is appropriate for describing the vitrain concentration in a layer of coal. It is evident, for example, that the middle layer of the block shown in plate 6 includes both thin and medium-thickness bands; discrete vitrain bands in the same range of sizes are shown on plate 7, but they are less abundant. Although the attrital coal of plate 7 is moderately bright, the actual concentration of vitrain bands more than one-half millimeter thick is less than 15 percent of the block.

Concentration terms, coupled with band thickness terms, can be used to give a concise and yet accurate verbal description of the vitrain in a layer. "Moderately thin-banded" may be taken as a short explicit way of saying that 15 to 30 percent of the layer is composed of vitrain bands $1 / 2-2$ millimeters thick. "Moderately thin and medium banded" would imply about the same amount of vitrain occurring in both the thin- and medium-band sizes, as in the middle layer of plate 6. Of course, if a definite percentage of concentration can be given, it will be advantageous to do so; however, more accurate measurement will usually require an approximation of laboratory conditions and more time than can often be spent on a single description in the field.

\section{OCCURRENCES OF FUSAIN}

Fusain is not nearly as abundant in coal beds as vitrain, and it commonly occurs in rather sparsely distributed thin separate lenticles which may be aggregated into fairly distinct laminations, as on plate 14, or even in larger lenticular pockets (pl. 12, fig. 1; p. 13, fig. 1) or layers. In view of its distinctive chemical and physical properties and its tendency to be lost from exposed surfaces in commercial coal because of extreme friability, it is highly desirable to obtain as much quantitative information as possible about the actual occurrence of fusain in the bed. 
The occurrence of fusain can be reported ir. the same manner as indicated for vitrain, except that all bands of fusain noted must be labeled explicitly. However, if fusain is not to abundant or too dispersed, it is desirable to indicate actual thicknesses of bands thicker than one-half millimeter. It is never possible to estimate fusain completely by megascopic methods, and all lenticles less than one-half millimeter thick and at least a centimeter (three-eights of an inch) wide should be ignored in a megascopic description. Smaller lenticles ("microfusain") contribute their characteristics to the attrital coal. The letter " $F$ " serves as a convenient abbreviation for fusain in field notes.

\section{OCCURRENCES OF ATTRITAL COAL}

- The principal terms used in describing attrital coal refer to luster and surface texture. In describing the luster of attrital coal, the "brilliant" luster of vitrain at the same locality is taken as a standard for comparison. Vitrain always is more lustrous than attrital coal associated with it and, by reference to this standard for maximum brilliance of luster, the following five terms are recommended to describe luster in attrital coal: Bright, moderately bright, midlustrous, showing an intermediate range of luster, moderately dull, and dull. It is believed that descriptions by different observers are unlikely to differ more than one step within the foregoing: series. This method of description will be most useful in comparison of coals of about the same rank because the luster of the vitrain "standard" has the same degree of brilliance for a particular stage of metamorphism but varies appreciably for different stages.

The most evident change in luster occurs as a result of metamorphism in the transformation of lignitic to sublituminous coal and is used as the basis for differentiating vitrain and previtrain. All ingredients in lignite generally show dull or very dull luster in the fresh (moist) unweathered condition. Lignite specimens shown on plate 11 are moderately dull. However, these surfaces are shown somewhat more lustrous than they were originally, because the surfaces had to be dried to illustrate inherent texture. As a result they also became checked before they were photographed. The luster of a lense of dry vitrain from subbituminous coal is shown on plate 10, figure 3. Some bands in lignite may take or a very bright luster after prolonged drying at an outcrop, but this requires special interpretation and should not be confused with the sccurrence of vitrain.

The surface texture of attrital coal can be described in ordinary terms of general usage, such as smooth, satiny, striated, silky, hackly, finely to coarsely granular, rough, or earthy. Itt is difficult to recommend a standard graduated series of terms because each variant has its own gradations and a comprehensive terninology might easily 
become complicated. However, a few illustrations can be cited to serve as examples.

Specimens illustrated on plate 11 show previtrain (woody) and attrital bands in lignite chiefly distinguished by differences in texture. Previtrain shows smooth texture with evident indication of grain in the wood. Attrital lignite is invariably rough or earthy on fracture surfaces, and its texture can be seen even on a rough saw cut (pl. 11, fig. 1; also note difference in checking) or on a surface that has been carefully smoothed as on plate 21, figure 4. Granular texture is characteristic of attrital layers of dull luster. Sometimes this is an indication of detrital impurity as on plate 21 , figure 1 , but coal with dull luster and granular texture, like that shown in the upper layer of plate 6 , is not necessarily impure. Finely granular texture is shown at slight enlargement in attrital layers on plate 10 , figure 2 , and in attrital bands in the lower part of the various figures, all illustrating different views of the same specimen, on plate 8 . Striated or silky texture is characteristic of much of the attrital coal in the specimen shown on plate 7. Midlustrous attrital coal of the middle layer shown on plate 6 , is striated to finely granular. The nonbanded specimen shown on plate 22 , figure 1 , may be described as having satiny texture. Texture of the "kolm" specimen on plate 22 , figure 3 , is a little coarser and shows a tendency to be hackly. Highly cleated bright attrital coal, like the upper parts in the specimen shown on plate 8 or the patches broken out of the polished surface of the specimen on plate 9 , can best be described simply as rough.

Unless specifically stated, descriptions of surface texture should be taken from new fractures and not from cleat planes. Cleat surfaces are old, and their appearance is commonly modified by surface films or facing deposits of secondary minerals. Even when the coal is clean, the cleat surfaces tend to be smoother and less definitive of inherent differences in the coal than new fractures. These differences are apparent in specimens shown in views of both butt and face cleat on plates 7 and 8 . New fractures are much more evident normal to the face cleat.

Whether it composes all or only a part of a coal bed, nonbanded coal should be described in the same way as attrital coal. Although its appearance is generally more uniform than the attrital part of most banded coal, differences in luster and texture may be significant for interpretation of variations established by correlation with microscopical information and analytic data.

\section{SPACING AND EXTENT OF CLEAT}

Cleat, or vertical jointing, is most commonly noted because it influences the breakup of coal during mining and preparation, handling, and shipment. Mine operators sometimes take advantage of 
cleat in planning the layout of underground mines, because coal breaks out most easily along cleat planes. The geologic significance of cleat is not well understood.

Cleat usually refers to the oriented and distinctive joint system characteristic of bituminous coal. The major joint system is called the face cleat, and the minor system is called the butt cleat. Commonly the face cleat is oriented nearly parallel to local or regional structure trends, and the butt cleat intersects the plane of the face cleat at approximately 90 degrees. Apparent correlation with structure has led to the theory that cleat is caused by pressure.

In spite of its common relation to structure trends, cleat is not always well oriented. This is sufficient to cast doubt on the pressure theory of cleat origin. Moreover, close observation shows that cleat is not merely a result of shattering when coal is broken in mining. Cleat planes represent minute fissures or separations normal to the banding, that exist naturally within the coal. The vertical fissure spaces are commonly mineral filled and microscopic study shows that plant structures were originally continuous across the spaces. Cleat evidently is not at all comparable to cleavage in minerals. Ball (1934) has described cleat fissures as desiccation cracks and it seems evident that cleat fissures are at least initiated by shrinkage. However, cleat shrinkage probably is not induced solely by desiccation since the same shrinkage could result from loss of volatile matter or by molecular condensation in organic substances composing the coal. Cleat does not appear during the sequence of incoalation until the organic material has lost much of its original moisture.

Lignite is not truly cleated since joints in lignite are very widely spaced or absent. Checking, owing to simple loss of moisture as shown on plate 11 , figure 1 , has no relation to cleat. In subbituminous and all higher rank coal, cleat is present in varying degree. Coal of low-volatile bituminous rank is noted for intensive cleat that causes the coal to break readily into small subcubical pieces. Intensive cleat is commonly visible in anthracite but the cleat separations, which frequently include a film of mineral, appear to have been solidly recemented, as on plate 17 , figure 1 . Evidently cleat has an important relation to rank.

Cleat separations do not extend uniformly throughout the bed. They are most closely spaced in vitrain and many die out on passing into attrital layers. Even erratic vitrinized fragments in shale may be highly cleated. Bright attrital coal may ke nearly as intensely cleated as vitrain, but dull and impure attrital layers show fewer cleat separations and a wider cleat spacing. Dull nonbanded coal is commonly as widely jointed as the adjacent noncoaly rocks. Fusain generally interrupts cleat separations and in itself is never jointed. 
Many of the differences between ingredients that are of practical importance may be traced, directly or in part, to differences in cleating.

The common appearances of butt and face cleat are illustrated by illustrations on plates 7 and 8 . Figure 4 of plate 8 has been illuminated so that the face cleat planes reflect the light and illustrate the strong parallelism that exists even in highly cleated coal. Plate 9 represents a polished surface of a block dominated by bright attrital coal in the upper part, with gradational transition below into an impure layer. This plane intersects the numerous face cleats and shows the number of cleat separations diminishing in coal containing detrital impurities. The cleat pattern is brought out in contrasting manner by a different mode of illumination used in photographing the polished surface specimen shown on plate 20 , figure 4 . The oriented mineral-filled cleat pattern shown in its horizontal aspect on plate 10, figure 1 , can be duplicated in many bituminous coals of intermediate rank. The vertical fracture surface of the same specimen, shown slightly enlarged on plate 10 , figure 2 , demonstrates termination of many of the cleat fissures as they pass into attrital coal. Cleat is nearly entirely limited to the bands of vitrain in the anthracite specimen illustrated on plate 17 , figure 2. In bituminous coal even small fusain lenses serve to terminate cleat separations, as shown on plate 14, figure 2 .

One of the less common types of cleat is represented by circular facets oriented parallel to the major cleat plane. Films of mineral may occur on facet surfaces, but commonly there is no visible connection from one facet to another. In coal of homogeneous consistency, as in vitrain or in uniform types of bright attrital coal, such as that illustrated on plate 22, figures 1 and 2, facets may be rather evenly spaced and numerous. Since all are parallel, the facets reflect light in unison, as in figure 2 of plate 22 , which was oriented with the facets at a critical angle between the light and camera lens. In a mine, the reflections tend to shine like eyes in the dark, and coal in which they occur may be called eye coal. If such coal is broken at an angle to the cleat, individual facets tend to be only partly exposed, and their roughly semicircular outline and spaced occurrence bear a superficial similarity to scales on a fish. For this reason, coal with circular cleat facets may also be called fish coal. Perhaps it would be better to speak of this type of cleat in coal as facet cleated; facet cleats may occur in the different kinds of coal which have relatively homogeneous lithology.

In areas of tectonic disturbance, cleat separations form natural points of weakness and displacement. A second set of joints may also be superimposed at an angle to the initial cleat system. Under strong deformation, cleats and joints may merge imperceptibly with minor 
slip planes. Locally, these slip planes may develop into intense slickensiding, microbrecciation, and mylonitization and may be ac-. companied by mass movement. Such features are characteristic of very high rank coal, as shown by specimens illustrated on plate 20 , figure 1, and on plate 24, figure 1.

No standard method of reporting cleat has been devised, but a compass bearing of the cleat systems at each lcicality and brief notes should be taken to describe cleat as it affects the coal bed as a whole. Where cleat dominates the general appearance of the coal, as it does for many coals of low-volatile, and at least some coals of mediumvolatile bituminous rank, it can often be best reported by means of photographs.

\section{SECONDARY AND AUTHIGENIC MINERAI OCCURRENCES}

The most conspicuous secondary minerals in coal occur as facings on cleat surfaces, as on plate 18 , figure 5. Some of the facing minerals can be removed by cleaning processes, and, in general, secondary minerals are not as serious to contend with in utilization of coal as the authigenic and primary impurities that were originally present in the peat. Even a thin film of surface mineral is detrimental to appearance, however, and can influence the sale of domestic coal.

The most important secondary minerals in coal are kaolinite (porcelaneous, not effervescent; pl. 10, figs. 1 and 2 ; pl. 17, fig. 2), calcite (white to transparent, effervescent; pl. 18, fig. 5), and iron pyrite or marcasite (pyrite; yellow to gray, opaque, sparkling crystal faces sometimes visible; pl. 19, fig. 1). The following minerals are of lesser importance and chiefly affect appearance: Limonite (brown surface stain), melanterite (a weathering product from purite appearing as a white surface film or small crystals), and "peacock" coloration (very thin iridescent films, usually of hydrated iron compounds). Many other minerals are occasionally present in coal as secondary deposits. Among these are quartz (pl. 11, fig. 3; pl. 15, fig. 3 ; pl. 16, fig. 4), gypsum, iron carbonate, analcite, and apatite. Ankerite (magnesium iron manganese carbonate) is often reported as a coal-facing mineral in British coal beds but has seldom been noted in American deposits.

Pyrite and marcasite occur most commonly as authigenic deposits of the original peat. These primary occurrences are in the form of concretions, as thin layers along bedding-planes, and as microscopic crystallites or spherulites disseminated in the coal. Small amounts of secondary pyritic facings also are fairly common on cleat surfaces. The pyritic concentration shown' on plate 19, figure 1 , evidently resulted from a combination of causes and probably represents an originally authigenic deposit to which secondary pyrite was added over an extended period of time. 
Marcasite appears to be rare in American coal and generally cannot be distinguished from pyrite in the field. The positive identification of disseminated pyrite is generally difficult unless $\mathrm{X}$-ray diffraction patterns are obtained. The simplest procedure usually is to describe these minerals as pyrite.

More spectacular examples of mineral occurrence are illustrated on plates 15, 16, and 18. The aggregation of fusain shown on plate 15, figures 1 and 2, evidently was silicified early in peat accumulation, since both delicate as well as fibrous fusinized plant tissues are represented. Some quartz is evident but most of the siliceous mineral is cryptocrystalline. Chalcedonic banding is present along the veinlet shown at the upper right in figure 1 , plate 15 .

Plate 16, figures 1-3, illustrates a siliceous microbreccia in which a coal bed and its associated rocks were disrupted after normal consolidation. Fracture surfaces of this material are dark and rough and appear quite coaly. Silification of this breccia was accompanied by deposition of traces of uranium. A milky quartz vein is shown associated with slickensided and graphitic meta-anthracite in a drill core from the Narragansett coal field on plate 16, figure 4. The surface photographed was etched with hydrofluoric acid to make its texture more evident.

The etched surface section of a calcareous nodule (coal ball) shown on plate 18 , figure 1 , represents a relatively rare occurrence that is of great importance in understanding the origin of coal. Such concretions represent authigenic deposits formed in peat prior to consolidation. Plant tissues are embedded in mineral and so permeated by it that the finest details commonly are faithfully preserved. Important knowledge of the actual plant materials that contributed to the consolidated coal can be gained from this type of petrifaction. Several kinds of plant material are identified in the photograph on plate 18, figure 1 , and one of the petrified plant stems is shown in cross section at $\times 100$ magnification in figure 4 . Pollen grains, like those contributing to attrital coal, are shown from a coalball section in their original undistorted form in the highly magnified figures 2 and 3. The outer surfaces of coal balls are drab or coaly, often slickensided, because of the compaction differential between surrounding coal and the mineralized peat. Where present they usually constitute an easily separated impurity in mining coal, but they contribute a great deal to understanding differences in origin of different beds of coal. Such occurrences are of great interest to paleobotanists and always deserve careful examination.

A description of a coal bed should always include some mention of the presence or absence of secondary or authigenic minerals. In some beds mineralization may be more prominent in certain layers. 
No standard procedure seems applicable for reporting all possible variations, but a brief notation of any common types can be easily entered in field notes.

\section{EFFECTS OF WEATHERING}

Weathering reduces the luster and decreases the contrast between coal ingredients. It is accompanied by oxidation and deterioration of original texture in the coal. Weathered outcrops are unreliable for coal description. Some features of differentially weathered coal, however, may be of interest and worthy of recording, although a systematic description of the coal bed as previously discussed will not be feasible.

"Leaf" coal, such as that recorded from the vicinity of Tula in central U.S.S.R., and "paper coal" more recently reported in this country by Guennel and Neavel (1958), evidently represents effects of differential weathering. The leafy character in both occurrences is due to an exceptional concentration of plant cuticle, a waxy covering layer that forms over exposed plant surfaces until they are shed or are covered with bark. Although "leaf" coal looks much like a layer of dead leaves, the cuticles are commonly derived from stems and petioles rather than from foliage. Under prolonged weathering other components of the original coal have been dissipated, but oxidation-resistant cuticles have persisted to constitute a soft fluffy deposit. Examples are illustrated on plate 23, figures 1 and 2.

A rather similar occurrence is represented by the "pine needle" coal shown on plate 23 , figures 3 and 4 , and reported by R. W. Stone (1912, p. 49), of the Geological Survey, from the Cambria coal field in Wyoming. At this locality, however, resinous secretions constitute the oxidation-resistant parts from which the less resistant coalified tissues were removed in weathering. The needles of resin are about the size of small pine needles and suggest the name locally applied.

These occurrences provide an indication of peculiarities of composition in coal beds. The process whereby oxidation-resistant materials are naturally concentrated through weathering is analogous to the artificial oxidation process wherein plant microfossils from coal are segregated for the purpose of identification and correlation of coal deposits. Occurrences such as "leaf" coal and "pine needle" coal are chiefly of geologic interest, but they also suggest peculiarities of composition that conceivably could be utilized in special applications.

\section{PREPARATION OF FIELD NOTES}

The importance of systematic procedure in preparing descriptive field notes cannot be overemphasized. These notes should be taken in logical sequence in order to avoid inadvertent omissions. The following check list summarizes the data presented in the preceding 
pages and should be of assistance in systematically preparing a descriptive field record. If this check list is adhered to, an omission will signify absence; and much time will be saved because it will usually be unnecessary to record what is not present in the field. Field notes should contain all essential details and be regarded as a permanent record to be kept available for future reference.

\section{Check list for preparing field notes.}

A. Locality by description or by coordinates to nearest one-sixteenth section where maps or land plats are available; if no plat is available, by odometer distance from a definite point, giving road name and direction.

B. Bed name, if known: otherwise. indicate or at least estimate distance above or below some identifiable stratigraphic datum; estimate actual position within the geologic member or formation.

C. Strike and dip; eleration (top of bed; indicate how determined).

D. Name of property owner or mine operator if this information may assist someone else in identifying the particular locality.

E. Conditions for observation (good, poor, obscure).

F. Commercial variety of coal (banded, nonbanded, mixed).

G. Description of coal bed.

1. Measurement profile (subdivision of bed according to lithologic character of layers, partings. impurities). Record top, bottom, and all layer and parting boundary measurements in millimeters in skeleton form; leave space for intercalation of all layer and parting descriptions called for in 2, "notes on coal lavers."

2. Notes on coal layers ( semiquantitative estimate of ingredients; omit if conditions for observation are poor or obscure).

a. Vitrain (in coals of higher rank than lignite; brilliant, vitreous bands). Previtrain (woody bands in lignite; lack vitreous luster).

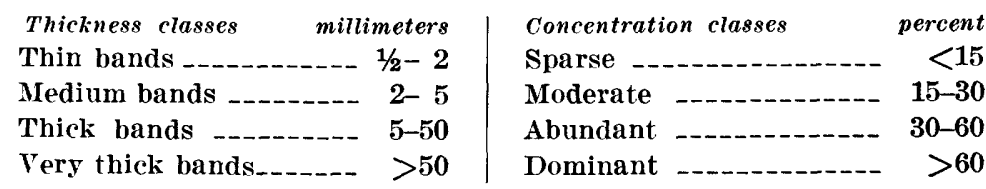

b. Fusain (charcoallike; dull).

Estimate thickness and concentration of bands in same manner as for ritrain, or give actual measurements, but indicate all fusain bands by the letter "F."

c. Attrital coal (the microfragmental matrix of banded coals and all nonbanded coal). Describe (1) luster (bright, moderately bright, midlustrous. moderately dull, dull), (2) surface (earthy, rongh, granular, silky or other appropriate terms-see p. 41).

3. Notes on impure coal layers and partings.

Describe, using geologic terms; state whether hard or soft in mining; use miner's terms only for identification.

4. Notes on cleat or jointing.

Describe as to (1) spacing and importance, (2) determine compass bearing of vertical cleat planes.

5. Notes on mineral occurrences.

Describe occurrence of common minerals (kaolinite, calcite, pyrite, or others). 
H. Rock strata adjacent to the coal bed.

1. Roof; give any descriptive details supplemental to standard notes on geologic section that may have importance for mining.

2. Floor; same as for roof (do not use fire clay unless the clay is known to be refractory; underclay is commonly a more suitable term).

\section{NOTES ON COAL SAMPLING}

\section{TYPES OF SAMPLES}

Samples of coal beds are essentially of two types: those that represent the continuous thickness of the coal bed and show natural lithologic and textural relations, and those that provide a uniform representation of the thickness sampled but which are mixed during the process of sampling. The first type may be further divided as follows: Column or pillar specimens, drill cores, and series of block specimens. Samples of the second type, usually called channel samples, are primarily used for establishing the bulk composition of the coal bed according to standard methods of coal analysis (American Society for Testing Materials, 1957; Fieldner and Selvig, 1938, 1951). Channel samples may also be taken from individual layers in a coal bed for more specific determination of composition.

Samples of coal taken from a mine tipple or from a commercial shipment are indicative only of the commercial product. Moisture tends to be lost, and the more brittle or friable coal ingredients often segregate in smaller sizes of broken coal subsequent to mining. Impurities tend to vary; they depend in part on mining practices. Thus run-of-the-mine coal usually differs from the original representation in the bed. Bed characteristics are of primary concern in the evaluation and estimation of coal resources.

Hand specimens of coal may be taken to illustrate certain specific features, or because representative samples are unobtainable, or for incidental reasons. Although specimens of this kind may be extremely useful, they can provide only qualitative information. They belong in a distinct category and should not be regarded as samples.

Accurate samples of coal beds may provide important geologic information. The type of sample to be taken is determined largely by the nature of the information desired. Channel samples, for example, may provide data for preparing maps showing variations in volatile matter, carbon, sulfur, ash, calorific value, and other elements that may reflect metamorphism or features of geologic interest. As determinations based on channel samples reflect inherent variations of the coal bed more accurately, it is posisible to attach much more significance for geologic interpretation to them than to analyses based on tipple samples or prepared sizes of commercial coal. 
Whenever close comparison of analytic data is attempted, it is most desirable to know the relative amounts of the main coal ingredients and whether the samples include comparable kinds of impurities. If field descriptions have been obtained at sampling locations, they will provide this information, and chemical analyses supported by these data can be evaluated much more critically.

Channel samples of coal beds also can be used for laboratory study of plant microfossils, such as spores, pollen grains, and cuticles, which are useful for paleontologic correlation. It is not essential that coal be unweathered to serve this purpose, although best results can be obtained from coal that is in place and uncontaminated by extraneous clay or modern rootlets. Outcrop exposures will usually provide good microfossil material even if only a generalized coal description is possible. (See page 37 ).

The method of sampling a coal bed has an important bearing on the study of its contained microfossils. It is commonly desirable to collect a channel sample from each of the separate layers that seem to be correlated from place to place, at each locality, using similarities in megascopic texture and relative position as a basis for layer sampling. The principles in this sampling for study of microfossil content are the same as for samples intended for chemical analysis, but requirements are less critical in that no special precautions against weathering or loss of moisture are necessary. An adequate uniform representation usually can be obtained if half a pound of sample is taken per foot of thickness of coal.

Sampling the coal bed in layers permits not only a more detailed comparison of plant microfossil assemblages than would be possible from a single channel sample but also an ecologic reconstruction of the succession of floral assemblages that contributed to the coal. In addition to this historical information relating to the accumulation of the coal bed, sampling by layers provides a much more assured basis for correlation over reasonable distances between isolated outcrops. Study of plant microfossils sometimes shows what significance can be attached to minor differences in lithologic types of coal in terms of their origin. It is commonly possible by this method of sampling to establish correlations of layers in coal beds within a matter of a few inches.

\section{CHANNEL SAMPLES}

Channel samples are generally taken for chemical analysis to obtain average values. Average values established for a mine may be used as a basis for rank classification (American Society for Testing Materials, 1957, p. 87). Many other valid generalizations may also be established from the analysis of comparable channel samples of a coal bed. 
In obtaining channel samples particular care must be taken to insure adequate and uniform representation, adherence to standards for rejection of impurities (partings and mineralized lenses), avoidance of areas of weathered or altered coal, and retention of naturally occurring bed moisture. Demonstration of the necessity for standard procedure in obtaining channel samples of coal beds, and institution of a practical method of effective mine sampling, is a direct outgrowth of the extensive coal sampling program in the United States which was carried out by the Geological Survey in connection with operation of its coal testing plant at the St. Louis Exposition in 1904. M. R. Campbell (1907, p. 56) and J. S. Burrows (1907, p. 448-490) first presented recommendations for mine sampling similar to those accepted with little modification by later authors (Holmes, 1911, 1918; Fieldner and Selvig, 1938), which are followed to the present day. It became evident as a result of the work at St. Louis that channel samples of coal taken at the mine face differ from samples of coal produced commercially. In order to evaluate coal resources, an arbitrary and rigorous procedure in channel sampling is necessary. This procedure is summarized in the numbered paragraphs following:

Procedure for collecting channel samples

1. Select a fresh face of unweathered coal, normal to the dip, at a place where the coal has not been long exposed to the atmosphere.

2. Clean the surface by chipping the face to a depth of at least 1 or 2 inches. The cleaned face should be straight and normal to the bedding. If the original surface is very irregular, more coal should be removed in cleaning.

3. Spread a rubberized sheet or oilcloth on the floor below the cleaned area to catch all pieces as they are cut for the sample, and to exclude floor moisture and all material not derived from the channel of sampling. The sheet should measure at least $1 \frac{1 / 2}{2}$ by 2 yards.

4. Cut a straight channel in the coal from roof to floor, approximately 3 inches deep and 4 inches wide, or sufficient to provide at least 6 pounds of coal for each foot of thickness of the coal bed. Care should be taken to exclude all roof and floor rock, partings or binders more than three-eighths of an inch (about $1 \mathrm{~cm}$ ) thick, and mineralized lenses or concretions (such as "sulfur balls") more than half an inch thick and 2 inches wide. All other material from the channel must be included in the sample.

5. Pulverize the entire sample as quickly as possible after cutting so that all pieces will pass through a screen with $1 / 2$-inch mesh. This work should be done under such conditions that loss of moisture can be minimized.

6. Thoroughly mix the sample, cone the crushed coal, and quarter; reduce the size of sample by rejecting opposite quarters. Alternatively, use a standard Jones riffle to reduce the sample into equivalent halves, one of which is rejected.

7. Repeat the process of thorough mixing and quartering (or riffling) until the sample has been reduced to a convenient bulk. Spread the mass of minus 1/2-inch coal in a circular pile about 2 inches deep and fill com- 
pletely a waterproof sample container (about 3-pounds capacity) with portions taken uniformly from the circumference to the center of the pile. A small metal sheet can be bent into a suitable scoop which will insure representation of fine and coarse pieces and avoid spillage in filling the container. Insert an identification label and carefully seal the container to prevent possible loss of moisture while the sample awaits analysis.

The most difficult step in this procedure, and one of the most important, is in crushing the full channel sample to minus one-half inch without a significant loss of moisture. Standard instructions direct that the coal should be crushed in the mine to avoid moisture changes caused by different atmospheric conditions. Mechanical equipment is needed in order to carry out this work effectively, but this is unavailable in underground mines. In opencut mines it is even more essential that the work be carried out quickly to preserve bed moisture in the sample. More accurate results are likely to be obtained if the complete channel sample is placed in moisture-proof bags or metal containers in the mine and taken immediately to available mechanical crushing equipment. The collector should make every effort to avoid circumstances that would reduce the accuracy of moisture determinations by allowing the moisture content to change from that normally present in the bed.

Because changes in humidity and temperature of the ambient air can have a strong effect on the amount of moisture in the sample, it frequently is advisable to seal hermetically a small supplemental sample of coal at the mine face, solely for the purpose of moisture determination. A quart jar of coal, taken from the back of the fresh channel cut, is sufficient for this purpose. Such a sample should include coal that is characteristic of the deposit, but it need not be collected with rigorous attention to its being representative of the entire bed. The moisture content of a coal bed at a sample locality is not likely to be as variable from top to bottom of the bed as the organic and mineral constituents. A small sample taken in this way, even though made up of coal well distributed through the thickness of the bed, is, of course, inadequate for any purpose other than as a check on bed moisture.

\section{BLOCK AND CORE SAMPLES}

Specimen block samples may be used for almost any purpose of chemical, petrologic, or plant microfossil study, providing no parts of the bed are omitted, or duplicated, and the blocks are adequately protected against moisture loss and fully labeled. The block specimens should be carefully keyed to a detailed field description of the coal bed at the point of sampling in order to minimize the possibility of uncertainty arising from loss of coal or breakage in transit from 
mine to laboratory. The top or bottom orientation and an index mark at some level on the specimen, giving the distance in millimeters from the top of the bed, should be placed carefully and legibly on each block. Most effective insurance against confusion in study of block specimen samples is provided by making the same person responsible for obtaining the coal blocks in the mine and for unpacking and carrying out initial preparatory work in the laboratory. If closely controlled chemical or petrologic work is contemplated, it is necessary to reconstruct the full profile thickness of the bed. For such a purpose block markings are very important; memory should not be relied on. Errors arising from faulty profile reconstruction cannot be compensating. Hence, any reasonable safeguard is well worth the additional effort that may be involved. For plant microfossil study, minor loss of material on partings and horizontal fracture planes is not as critical. Much of the difficulty in utilizing more or less fragile block specimens for quantitative studies can be obviated by reasonable attention to labeling and packing, and to initial coal-bed descriptions.

Coal drill cores provide the only means of effective sampling at a distance from mines or outcrops. Experienced drill operators can obtain virtually complete recovery in almost any type of coal, but experience in coal drilling seems to be very important. Great care must be exercised by the driller because the physical properties of coal usually differ greatly from those of enclosing rocks and partings. Coal beds are so hetergeneous in composition that nearly complete core recovery is essential for purposes of adequate sampling.

If core recovery is complete, there should be no cause for discrepancy or uncertainty as to depth or thickness of each coal bed. Since at least a minor loss always occurs in drilling, it is important that bottom depths be recorded at each pull of the core barrel. If convincing evidence exists as to the position and amount of loss within the core resulting for a pull, this should be noted and the note included in packaging the core. In the absence of such evidence, it is customary to assign the interval of loss to the top of the sample resulting from each drill run, because the greatest likelihood of loss occurs at the start of a run. No loss should be attributed to a depth beyond that reached by the run of the drill in which the loss occurred, but mistakes of this nature have been made when pull depths were not recorded.

Cores can provide quantitative information for most purposes of laboratory study but are likely to be high in bed moisture because the core comes initially in contact with water used in drilling; subsequently, if cores are exposed, they may become excessively dry. Excess water is generally present as the core is delivered from the 
core barrel; and, if there is no subsequent moisture loss, "as received" analytic values will inevitably be high in moisture. However, it is possible in the analytic laboratory to equilibrate the coal at saturation corresponding to natural bed conditions and thus to obtain an accurate value, if most of the moisture has been retained. Samples that have been allowed to become thoroughly dry probably never completely regain their original moisture. Not many analyses of moisture equilibrated coal samples have been made because an accurate bed-moisture determination is not critical for most commercial purposes, and only the moist analytic values will be much affected by an excess of water. Accurately equilibrated determinations should be obtained more often in the future to serve as bases for critical comparison.

As mentioned previously in the discussion about conditions for observation (p. 36), the drill-cut surfaces of coal cores are unsuitable for purposes of megascopic description. Generalized observations of obvious partings and lithologic divisions often can be made in the field; but, considering the cost of drilling and the limited amount of material in a core that is available for study, it is generally more economical to defer any attempt at detailed description until the core has been transported to the laboratory. Description of a satisfactory procedure for boxing and preparing cores for shipment is given on page 63. Under laboratory conditions it is possible to obtain a much more complete and more accurate description than in the field, and adequate provision can be made in the laboratory to avoid any exposure that would influence analytic results. Attention in the field may be best directed toward proper packaging of coal cores to retain moisture during transportation to the laboratory and toward maintaining a careful check on depth markings of the core so that no question arises in correlating the more detailed laboratory description with depths recorded in fieldwork.

Inadequate packaging of coal core can result in damage other than loss of moisture. Atmospheric exposure will result in oxidation effects that may be difficult to evaluate. Coal with high inherent moisture will shrink and check as it dries, and in this condition it has much less value for petrologic study. On the other hand, plant microfossils can withstand excessive exposure and, for paleontologic purposes, core stored for many years can be used.

\section{COLUMN SAMPLES}

Column or pillar specimens of coal are expensive to collect and transport, but they offer many advantages for study. In obtaining a column specimen of a coal bed, the objective is to transfer to the laboratory a monolithic block of coal that represents the entire thickness of the coal bed. If care is used in packing, a column of highvolatile bituminous coal 12 to 14 inches square generally is large 
enough to hold together for transportation. Column specimens of larger dimensions may be required if the coal is very thick or soft like lignite, or is excessively cleated like most coal of low-volatile bituminous rank.

Column specimens serve to eliminate any question about textural relations or relative position that may arise during study of a series of block specimens. The column specimens are large enough to provide sufficient coal for detailed sampling of each layer or lithologic unit, and they thus permit study by a number of methods with complete assurance of exact correlation within the column. Although it is not practicable to seal large column specimens hermetically to conserve all moisture in shipment, they are large enough that, with care in packing, moisture loss from central parts is minimal. For purposes of chemical analysis, the most uniform sampling possible by any method can be accomplished once an adequate column specimen has been obtained. When the column specimen is available in the laboratory, reliable descriptive information can be provided in whatever detail is desired; and accurate specimen blocks from the column can be saved for future reference. As a complete column specimen is essentially a section of the mine face, there is a minimum dependence on notes and labels that have to be prepared within the mine. All that is required is for the top and bottom of the bed to be marked unmistakably. Complete information about the character of coal at a given bed locality usually cannot be obtained by any less elaborate method of sampling.

Thiessen, Sprunk, and O'Donnell (1938) have described one method of obtaining satisfactory column specimens of bituminous coal. They advocate drilling a series of horizontal holes along the vertical lines where the column is to be separated; coal between the holes can then be broken out without damage to the column. The process can be further simplified in mechanized mines where a universal type of coal cutter is available. The cutter bar, turned in vertical position, can be used to free the column specimen from the coal face. Headlee and McClelland (1955) have devised a diamondsaw mounting that can be used for obtaining 3-inch column specimens from the coal face in operating mines. Small column specimens, however, are more subject to breakage and loss than larger specimens. Also, since the saw blade is cooled by water, these column specimens have about the same limitations as diamond-drill cores. In spite of the difficulty and expense of obtaining adequate column specimens for correlated studies using many types of tests and analyses, programs of investigation have been conducted based on column specimens of coal. The formidable problems that are inherent in all the types of coal-bed sampling justify this costly procedure. 


\section{SUMMATION OF COAL-BED INFORMATION}

Trends of variation in the coal are of considerable interest in any coal area. They are most easily shown by means of isonomic maps with "contour" lines delimiting areas similar in certain conditions or properties. From such maps inferences may be drawn regarding qualities or properties of coal not capable of interpretation at single outcrops, and about conditions that govern coal deposition. Maps of this type provide a means of systematic presentation of results that is readily understood, and any trends that can be demonstrated will have both practical and theoretical implications.

The presentation of data on quality of coal is a logical extension of areal studies that in the past have chiefly been concerned with the extent of coal deposits. Quality considerations go hand-in-hand with estimation of the quantity of coal. These studies should make it possible to predict within close limits not only the gross amount of coal available but also the different kinds of coal that are included. Such information would be of assistance in future development of mining districts.

As indicated on preceding pages, a number of significant variations in coal can be distinguished by megascopic study; others can be interpreted megascopically with recourse to a moderate amount of critical microscopy and pertinent analytical data. These qualities of coal can be mapped. It is unlikely that it would be desirable to present all of them cartographically for any given coal field or district. A preliminary review of field notes and analytic data and trial plotting of these data on base maps should suggest which qualities, properties, and conditions are likely to show significant relations within some given area. Some of these possibilities are indicated by the discussion below.

\section{THICKNESS CHARACTERISTICS}

Thickness data may apply to either the entire coal bed or to correlative layers of the bed, such as those distinguished by lithologic characteristics, impurities, partings, or to concentration of coal ingredients. A summary of partings and banding impurities is essential to compilation of coal-reserves information. Isopach presentation may have further value in planning mining development or in reconstructing the topography and sedimentary conditions that existed in the antecedent "coal" swamp.

A summary of overburden thickness is most desirable wherever opencut mining operations may be feasible. These data may be presented most effectively by mapping the interval between the topographic surface and the top of the coal bed. 


\section{CONCENTRATION OF INGREDIENTS}

Wherever knowledge of vitrain content is important, as it is likely to be in districts with borderline coking coals, maps showing trends of vitrain concentration may have considerable economic usefulness. Data for plotting may be obtained from field notes prepared according to instructions on page 47 to 49 . A rough, but probably adequate, numerical estimate of vitrain concentration can be compiled for each locality description simply by assigning median values to the adjectives used to describe the concentration of vitrain in each layer of the bed. Sparse concentration would be regarded as an approximation of about $71 / 2$ percent concentration, moderate concentration as approximating about $221 / 2$ percent, abundant concentration about 45 percent, and dominant concentration 80 percent. In study of areas where vitrain mapping is likely to prove useful, an effort should be made to check the validity of such median values; a few specimens should be obtained in which vitrain can be measured. These specimens can be referred to as examples of more accurate vitrain determinations. The measured determinations should be used to gage the accuracy of estimates that lack as much refinement. Personal familiarity of the geologist with the coal that was studied to obtain these data probably is the best guarantee of reliable results.

Mapping of the vitrain should show areas of greatest concentration and least concentration, on the basis of enough observations to define the areal scale on which the differences occur. Consistency in illustrating relative differences is more important to this work than adherence to a narrow standard of numerical accuracy. If numerical values become critical, special studies that employ more precise analytic control can be instituted. However, such special studies are costly and time consuming; they are, by nature intensive rather than extensive. The primary service of the geologist should be to point out first where more intensive investigations can be particularly advantageous or effective in promoting proper use and conservation of coal resources.

The possibility of mapping the occurrence of fusain should be considered, using the field data in essentially the same way as suggested for mapping vitrain. Maps illustrating variations in fusain concentration have at the present time rather intriguing possibilities because of the general obscurity of the mode of origin of this distinctive ingredient and because of its special significance in domestic and industrial uses of coal. Much of this obscurity is probably a result of the lack of systematic inquiry that a painstaking geologist may be in position to employ.

The foregoing discussion illustrates two of the possible uses of concentration data. Others are likely to be suggested by conditions peculiar to different areas. 


\section{STRUCTURAL HISTORY AND MINERALIZATION}

It is generally believed that the orientation of cleat in coal reflects geologic stresses more delicately than the jointing of other sedimentary rocks. If this is true, additional refinement can be added to an understanding of the structural history of an area by systematically plotting the directions of cleat on a base map. Vitrain streaks in shale often show cleat as conspicuously as in a coal bed, and the orientation of these cleat planes can be recorded if further observations are needed to supplement other records. Conversely, the application of this method and comparison with other structural features may also have a further implication about the origin of cleat in coal. The spacing of cleat has a practical significance in the mining and marketing of coal, and it doubtless has a theoretical significance that still is poorly understood.

It is of interest to know whether secondary mineralization in coal follows any particular pattern of areal distribution. Transposition of such mineralization data from field notes to a base map also may help bring out unsuspected relations that bear on past geologic history of the coal area and on its future commercial development.

\section{USE OF ANALYTIC AND COAL-TEST DATA}

Maps showing isovols, isocarbs, carbon ratios, and other features have been prepared by various authors, mainly as a means of illustrating generalized concepts. Similar data can be plotted to serve more immediate and practical descriptive purposes over small areas, provided there is careful control of the original sampling. Cartographic arrangement of this type of data is likely to bring out relations that would otherwise escape notice.

Analyses of channel samples of the entire coal bed are most important to geologists, as such samples are the standard basis for determination of rank. Many reliable analyses are available for coal in all the coal fields of the country, and they serve as the best general basis for comparison or classification at the present time. However, only a small proportion of these analyses is based on channel samples. The remainder are made from the mine tipple or from commercial lots of coal delivered. As pointed out (p. 49), such samples may differ appreciably from the coal as it exists in the bed.

Inasmuch as coal is one of the more sensitive indicators of regional metamorphism, analytic coal data, properly used, should make possible the illustration of the effects of local or regional metamorphism in any area studied. Interpretations of greatest refinement would require allowance for variation in type and grade, such as may be indicated by detailed descriptions. Different methods of calculation and representation have been used by different authors to serve this 
purpose in the past, and some difference of opinion may still exist as to the best and most reliable practice. In general, values on a mineral-matter-free basis have much to commend them; however. regardless of how analytic data are computed or calculated, the most critical factor of all is in regard to the original coal sampling. If the sampling conditions and procedures are known to be comparable, there will be less difficulty interpreting analytic results.

Sulfur has many deleterious effects in the utilization of coal, and its occurrence is frequently of much practical interest. Detailed studies have shown that the amount of sulfur in coal varies locally, but little has been accomplished in showing reasons for this variation. The variations in sulfur content and in its occurrence still present a challenge to geologists in many areas where sulfur is likely to be a critical factor in utilization.

The geologist should remain alert to the possibility of submitting carefully selected samples of particular ingredients or types of coal for analysis to assist in geologic interpretation. Such samples may provide a basis for greater insight into inherent coal characteristics than channel samples, which show only average characteristics of the bed as a whole.

\section{SPECIAL EQUIPMENT AND SUPPLIES USEFUL IN FIELDWORK ON COAL}

Detailed description and sampling of coal beds should be regarded as a special part of the geologist's job. Ordinarily only a few of the many places in an area where coal can be seen are favorable for obtaining reasonably complete descriptive data. Most exposures are not suitable for sampling for chemical analyses. It usually is necessary to have advance information about the locality in order to anticipate and plan for the special kinds of work it may be possible to accomplish. Suitable equipment should be selected for this special work; proper equipment makes it easier to do a better job.

The following items will be useful in obtaining detailed coal-bed descriptions or in sampling. Standard tools, such as a geologic hammer, Brunton compass, hand lens, strong pocketknife, Locke level, and notebook, need no special mention as these are usually carried by geologists on every field excursion, whether or not advance information is available about the beds exposed. Not all equipment listed will be needed on any occasion, but some will be useful at every coal exposure that offers the possibility of detailed study. Some comments have been added about uses and about adaptations of standard items generally available. Nevertheless, the list cannot be considered comprehensive. An ingenious and resourceful geologist will probably find additional items and adaptations that will expe- 
dite his work. Every mine or coal exposure presents a slightly altered, practical problem for description or sampling. Prior knowledge, a well thought out plan, and appropriate equipment will overcome many difficulties.

1. Coal-digging equipment :

a. Dutchhead coal miner's pick with extra replaceable points. Ordinarily the heads have opposing sockets for opposing points. If one of the sockets is modified to provide a hammer peen, the pick becomes more generally useful. A supply of sharp replacement points should be kept on hand.

b. Lightweight mattock or heavy trenching tool. Such an implement facilitates clearing off weathered exposures for collection of plant microfossil samples or, sometimes, for a generalized description of the coal.

c. Hammer with long thin chisel point about $1 \frac{1}{4}$ inches wide. Such hammers are not generally available. but some types of brick hammer can be modified to serve the purpose. Any chisel point hammer works better on coal if it is kept relatively sharp.

d. Short-handled shovel. Generally useful in moving coal cut in preparing a coal face for description or sampling.

e. Coal chisels with thin blades about three-sixteenths of an inch thick, 2 inches wide, and 6 to 12 inches long. They should be well tempered and evenly tapered to an acute chisel point. Thin blade floor chisels are suitable. and on occasion, a good chisel can be made by any metal worker from a large flat steel file. Two or three such chisels aid materially in collecting block specimens from a particular layer of a coal bed.

2. Equipment for cleaning coal surfaces for description.

a. Heavy whiskbroom or brush. Usually this will serve to remove loosely adherent dust and coal particles.

b. Hand brush with finer bristles than indicated under "a." Used dry, such a brush aids in removal of closely adherent dirt that may obscure small areas of the coal face.

3. Equipment and supplies for labeling and marking coal surfaces.

a. Wax pencils, light-colored: orange or red is good.

b. Scribing implement. A suitable scriber can be prepared from a spike by sharpening with a bench grinder.

c. Coarse-point fountain pen for writing on binding tape.

d. Cloth adhesive tape. about 2 inches wide; nonelastic type used for athletic bandaging.

e. Smooth-surface masking tape. The type of surface is important since it must hold a legible ink marking.

4. Wrapping materials and container for coal samples.

a. Aluminum foil is suitable for initial wrap of specimen blocks to retain moisture, but it must be packed to avoid abrasion or tearing. Heavy waterproof. waxed kraft paper is more suitable for lining core boxes. Polyethylene freezer bags retain moisture well but do not resist abrasion: a double-weight freezer bag placed inside a canvas sample sack may be adequate. especially for smaller specimens.

b. Canvas sample sacks are useful for taking samples if moisture is not an important consideration. Small sample bags are suitable for plant microfossil samples if the weave is tight enough to retain the dust: 12 by 20 inch sample sacks are useful in collecting block specimens. 
Burlap material (or large burlap bags) will be needed for wrapping if column specimens are collected.

c. Heavy plastic pillow covers with zipper fastenings have been used very successfully to enclose cartons of subhituminous coal core and retain moisture during shipment.

d. Coal scientists at Pennsylvania State University have used standard metal containers and hand canning equipment successfully for shipment and storage of high-moisture lignite and peat samples.

e. Galvanized-metal screw-cap containers with moistureproof gaskets, with a capacity of about 3 pounds of coal crushed to minus one-fourth inch, are used by agencies of the Federal Government to transmit samples for analysis to the U.S. Bureau of Mines.

f. Large metal lard cans of 50- or 60-pound capacity, with a friction top, are suitable for temporary use in transporting coal of the gross channel sample to a mechanical crusher. If samples are to be carried more than a few miles, the top should be securely taped on the can and the seal made substantially moistureproof. Such cans usually can be obtained locally from large commercial establishments.

g. Cardboard ice-cream containers are satisfactory for storage of crushed coal but are not moisture proof. They are not strong enough for individual shipment and. if they are used for shipment, must always be securely packed in a protecting box or stronger carton.

h. Heavy oilcloth or rubberized material at least $4 \frac{1 / 2}{2}$ hy 6 feet is needed for use as a sanple sheet to receive the coal as it is cut down in obtaining a channel sample.

5. Illumination (in underground mines).

Electric cap lamps with spot or focusing spot reflectors are satisfactory for general work. A geologist should ohtain, as part of his personal field equipment, a well-fitted safety hat to which the cap lamp can be attached. A broad leather or web helt with strap for attaching the storage battery of the cap lamp is also needed. Flood lamps, with batteries stronger than those provided with cap lamps, are suitable but must be carried hy hand and are usually impractical unless two or more persons are in the party. Dry-cell flashlights and open carbide lamps are generally unsastifactory for observing details of the coal at the mine face.

6. Photographic equipment.

Cameras with f3.5 or faster lenses are generally suitable if equipped with a bulb adjustment on the shutter. This will be needed if flashbulb pictures are attempted in underground mines. Procedure in coal-mine photography requires two persons for hest results: the cameraman determines the focus and area of the picture; the other person focuses a spotlight on different areas of the coal face so the areas are visible in the viewing device on the camera. The cameraman holds this position and, while the lights are off, opens the shutter of the camera. The assistant then sets off flashbulbs arranged to illuminate the area uniformly in the photograph. With care, successive flashes can be used to illuminate a larger area. The cameraman closes the shutter after the flash; the duration of the flash thus determines the length of effective exposure. The procedure outlined has the advantage of heing relatively foolproof. It does not depend on much equipment or synchronization of the camera shutter.

Owing to the preponderance of light-absorbing area in coal mines, greater illurnination intensity is desirable than in normal flash photography. If only one flash exposure is needed for a picture, the camera can be held

$5892350-60-6$ 
by hand satisfactorily; if a succession of flashes is needed, the camera must be rigidly mounted on a tripod.

Electric flash equipment is desirable if a large number of photographs are to be taken, because this eliminates the need for carrying a large number of bulky, fragile flashbulbs. Good detail pictures can be obtained, however, by use of a single small-size flashbulb. A carrying case for the camera and other photographic equipment is advisable.

7. Measuring.

A 6-foot steel roll tape, graduated both in millimeters and in inches, is most convenient in obtaining index measurements of a coal hed as required for description of a well-exposed coal face.

Approximate equivalents in inches and millimeters can be read directly from the opposing scales on such a tape.

If the tape is not equipped with a wire loop at the end, a small metal strap, bent to attach a loop wire, can be soldered to the tab at the end of the tape. The wire loop is used to fasten the end of the tape for measurement of a coal face. A small 15-centimeter (6-inch) ruler is useful for detailed studies of band frequencs in block specimens of coal.

\section{CORE BOXES AND CORE SHIPMENT}

Coal differs from most other types of mineral commodities in its susceptibility to drying and oxidation. Both affect the validity of ordinary analytic results. Because valid analytic results are an important consideration in justifying the expense of core drilling, coal cores must be carefully protected from moisture loss. It is also important to safeguard the coal core from damage or loss after it has been obtained.

One method for accomplishing these objectives is indicated in the following paragraphs. Directions are given for construction of a single-row core box suitable for receiving and shipping $\mathrm{N}-\mathrm{X}$ core (21/8-inch diameter), the size most commonly obtained in coal exploration. Details of construction and packing the core box are indicated in figure 3. For different sizes of core the dimensions can

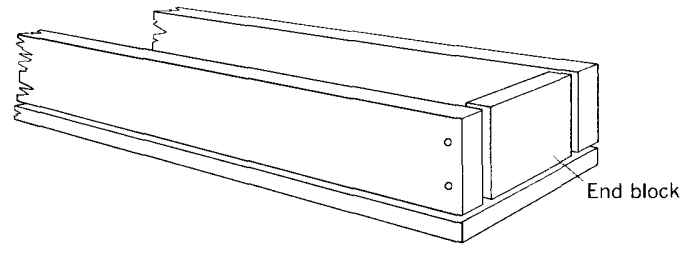

A

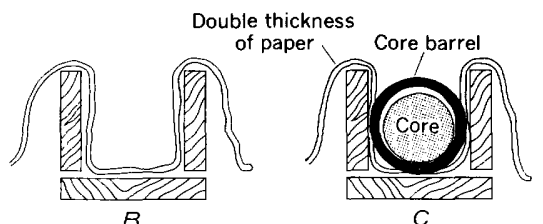

Figure 3.-Construction and packing of single-row core box.
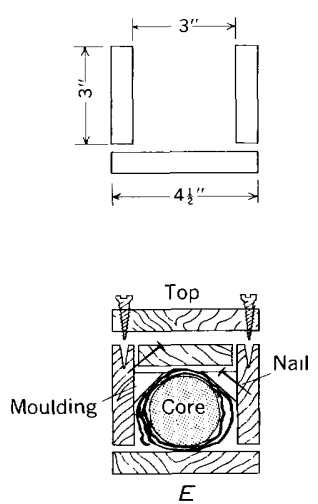
easily be altered. The procedure described has the advantage of involving the least handling and exposure of core under field conditions. Use of other types of core boxes involves separation of the core into standard lengths and less positive provisions for specific depth marking. These factors place an added burden of interpretation on the laboratory and are more conducive to costly mistakes. The author recommends this method because it is practical and thus serves in consistently obtaining accurate results.

\section{SUPPLIES FOR MAKING COAL CORE BOXES}

1. No. 2 grade, 1 - by 8 -inch lumber (which actually measures about $13 / 16$ by $7 \% / 16$ inches) and as long as is practical for hauling. Each of the 1 - by 8 -inch pieces should be ripsawed into a 3 -inch and a $41 \frac{1}{2}$-inch strip.

2. Quarter round or scrap moulding, 3/4-inch size, of about the same length as the lumber. If moulding is unobtainable, triangular strips that approximate the dimensions of moulding can be easily prepared from 1-inch lumber by use of a powersaw.

3. A supply of nails suitable for holding the 1-inch lumber; screws at least $11 / 2$ inches long; a supply of small nails suitable for nailing the moulding strips without splitting.

4. A roll of good-grade waxed, (waterproof) butcher paper, 28 or 30 inches wide. Usually this can be obtained from frozen-food lockers or at wholesale supply houses in larger towns.

5. Tools: crosscut saw, claw hammer, drill with bit of proper size to fit the screws previously listed, screwdriver, and try square.

\section{CONSTRUCTION OF CORE BOX}

Nail 3-inch side boards securely to a $4 \frac{1}{2} 2$-inch bottom board, forming a long open-end trough. Saw 3 - by 3 -inch end blocks from one of the boards. Nail one of the end blocks so that it closes one end of the open trough (fig. 3A).

Line the trough with a double thickness of waxed paper, permitting the edges to lap over the sides, as shown in figure 3B. About 8 inches of paper should be folded upward at the closed end of the box.

\section{INSTALLING CORE IN BOX}

After the core barrel is pulled from the drill hole, hold the core in place as the bit and retainers are removed. Lay the core barrel inside wax paper in box (fig. 3C) and push the core, withdrawing barrel at the same time from the open end of core box so that the core occupies its appropriate position for shipment in the box. Be careful not to tear the wax paper in withdrawing the core barrel.

Make field notes and any measurements desired at this time. As a general policy, the core should not be handled or pieces removed 
from the core box in the field. The core can be adjusted, however, by sliding lengthwise in the core box if parts are not badly broken. Pieces of floor and roof rock, and all partings up to about a foot thick, should generally be left in the core box as nearly as possible in their original contact with the coal.

Depth measurements should be marked with heavy lead pencil on top edges of the core box side boards, with cross marks on the wood indicating the precise level intended. Depth marks must be legible. Be sure to mark the depth of the bottom of a pull. It is often advisable to place a marked divider block to separate core taken on either side of a pull depth. The pull depth measurement is the most reliable of any that can be easily determined.

A minor loss from the material cored is to be expected; however, broken core can swell to suggest recovery of more than 100 percent. The probable position of losses can sometimes be suggested, either from operation of the drill or during initial inspection of the core. Unless there is convincing indication otherwise, it is customary to accumulate any loss from drilling at the top of the interval drilled.

Wrap the core by gently rolling it against one side of the box and tucking the wax paper from one edge snugly around the opposite side of the core; then roll it back toward the other side of the box (inside the wrapping just applied) and tuck the opposite edge of the wax paper snugly as far around the outside of the previous wrapping as possible (fig. 3D). This should result in the core being securely encased in an almost complete double layer of double thickness heavy wax paper. Fold the paper at the ends back over the top of the core. Make sure that the bottom end of the core is fitting snugly against the end board in the box and that the measurements marked on the side of the box are actually in register with the core after it is wrapped.

Tack moulding strips to sides of the core box so that they fit tightly against the wrapped core (fig. $3 \mathrm{E}$ ). This will hold the wrappings firmly in place and prevent the core from shifting in any direction during shipment. The open end of the box should now be closed by another 3- by 3-inch block. This end block should be placed in close contact with the top-end wrapping of the core. The excess length of side and bottom boards is now sawed off flush with the top end block. It is sometimes advisable to place a 1 - by 3 -inch board above the moulding inside the core box, as shown in figure $3 \mathrm{E}$. This will fill the box solidly, and the 1 - by 3 -inch board, when nailed in place, serves to tighten the core in the box.

The top of the box (same dimensions as the bottom) can now be tacked in place. Screw holes are now drilled through the top and into the side boards (fig. $3 \mathrm{E}$ ); usually screws placed about every 
18 or 20 inches are adequate insurance against damage, but additional screws can be inserted if they are needed to reinforce any weakness. Screws are much more dependable than nails in making the core box secure for shipment.

\section{CORE-BOX DATA CARD}

The field geologist should prepare an informal note card with pertinent data and comments and suggestions for guidance of the laboratory. The note card should be placed inside the core box after the core wrappings have been secured. These notes should include the project number, hole number, hole location, date of dirilling, and a brief indication of how the core has been logged in the field geologist's notebook. This is important as a means of coordinating field notes with the laboratory records that are relied on for more specific information. The informal field note should also indicate the nature of analytic data that is desired; it should give the field geologist's name and the address to be used in forwarding a laboratory report.

\section{SHIPMENT}

The core should be shipped to the laboratory, by a means that will insure prompt delivery, as soon as possible after coring. The outside of the box should be clearly marked, using paint or heavy shipping crayon, with project number, hole number, and box number (if more than one box of core is likely to be shipped from a given drill hole). A legible shipping label, giving address of the laboratory to which the core is directed, should also be prepared. Shipping labels often can be conveniently filled out beforehand and tacked securely on the core box tops, as they are needed.

\section{ILLUSTRATIONS}

The plates accompanying this report show, at approximately natural size or at low magnification, megascopic features of American coal and a few other types of carbonaceous rocks that may be confused with or are related to coal. The ratio of magnification or reduction is given for each specimen and has been determined from a scale placed in the plane of the surface photographed and measured directly from its photographic image. Negative numbers given for each illustration refer to the photographic collection at the U.S. Geological Survey Coal Geology Laboratory in Columbus, Ohio. Most of the illustrations are from specimens studied during the years 1949-1959, but some were obtained from core material previously photographed by the writer when he was employed by the U.S. Bureau of Mines. Photographs for which the author is not personally responsible have been credited in each instance. 


\section{LITERATURE CITED}

American Society for Testing Materials, 1957, ASTM standards on coal and coke: Philadelphia, Pa., 129 p.

Ball, C. G., 1934, Kaolinite in Illinois coal : Econ. Geology, v. 29, no. 8, p. 767-776.

Bergquist, S. G., 1939, The occurrence of spore coal in the Williamston basin, Michigan: Jour. Sed. Petrology, v. 9, p. 14-19.

Bode, Hans, 1929, Zur Kenntnis der Gattung Porodendron Nathorst (non Zalessky ) : Palaeontographica, v. 72, p. 125-139, 3 pls.

Burrows, J. S., 1907, The importance of uniform and systematic coal-mine sampling: U.S. Geol. Survey Bull. 316, p. 486-517.

Camphell, M. R., 1907, The value of coal-mine sampling: Econ. Geology, v. 2, no. 1 , p. $48-57$.

Fieldner, A. C., and Selvig. W. A., 1938, Notes on the sampling and analysis of coal : U.S. Bur. Mines Tech. Paper 586, 48 p.

1951, Methods of analyzing coal and coke: U.S. Bur. Mines Bull. 492, $51 \mathrm{p}$.

Fieldner, A. C., Davis, J. D., Reynolds, D. A. Selvig, W. A. Sprunk, G. C., and Auvil, H. S., 1939, Carbonizing properties and petrographic composition of High Splint-bed coal from Closplint mine, Closplint, Harlan County, Kentucky: U.S. Bur. Mines Tech. Paper 599, 38 p., 25 figs.

Guennel, G. K., and Neavel, R. C., 1958, Paper coal in Indiana: Science, v. 129, p. 1671-1672.

Headlee, A. J. W. and McClelland, R. E., 1955, Part III-Some physical properties of the coals, in West Virginia Geological Survey Volume 13 (A): Morgantown, West Virginia Geol. Survey, p. 1-24.

Holmes, J. A., 1911, 1918, The sampling of coal in the mine: U.S. Bur. Miner Tech. Paper 1, p. 1-18 (repr. 1918).

Howell, J. V., chm., 1957, Glossary of Geology and related sciences, a cooperative project of the American Geological Institute: Am. Geol. Inst. Pub. 501, $325 \mathrm{p}$.

Reinemund, J. A., 1955, Geology of the Deep River coal field, North Carolina: U.S. Geol. Survey Prof. Paper 246, 159 p.

Schopf, J. M., 1956a, A definition of coal : Econ. Geology, v. 51, no. 6, p. 521-527. 1956b, Petrologic methods for application to solid fuels of the future: Min. Eng., v. 8, no. 6, p. 629-639; Am. Inst. Mining Metall. Engineers Trans., v. 205 , p. $629-639$.

Sprunk, G. C., Selvig, W. A., and Ode, W. H., 1938, Chemical and physical properties of spores from coal: Fuel in Sci. and Practice, v. 17, no. 7, p. 196-199.

Stone, R. W., 1912, Coal near the Black Hills, Wyoming-South Dakota: U.S. Geol. Survey Bull. 499,66 p., 7 pls.. 8 figs.

Thiessen, R., Sprunk, G. C., and O'Donnell, H. J., 1938, Preparation of thin sections of coal : U.S. Bur. Mines Inf. Circ. 7021, 8 p., 12 figs.

Toenges, A. L., Turnbull, L. A.. Neale, Arthur, Schopf, J. M., Abernethy, R. F., and Quinn, A. W., 1948, Investigation of meta-anthracite in Newport and Providence Counties, Rhode Island; petrography, chemical characteristics, and geology of deposits: U.S. Bur. Mines Rept. Inv. 4276, 37 p., 24 figs.

Toenges, A. L.. Turnbull, L. A., Williains, Lloyd, Smith, H. L., O'Donnell, H. J., Cooper, H. M., Abernethy, R. F., and Waage, Karl, 1949, Investigation of lower coal beds in Georges Creek and north part of upper Potomac basins, 
Allegany and Garrett Counties, Maryland; reserves, petrographic and chemical characteristics of coals, and stratigraphy of area: U.S. Bur. Mines Tech. Paper 725, 142 p., 31 figs.

Tyler, S. A., Barghoorn, E. S., and Barrett, L. P., 1957, Anthracitic coal from Precambrian upper Huronian black shale of the Iron River district, northern Michigan: Geol. Soc. America Bull., v. 68, no. 10, p.o1293-1304. 



\section{INDEX}

\begin{tabular}{|c|c|}
\hline & \\
\hline $25-26$ & Clarant.......... \\
\hline ert coal. See Albertite. & Cleat, definition..... \\
\hline Ibertite & directions....... \\
\hline lgal remains in coal & origin $\ldots . . . .$. \\
\hline lum shale of Sweden & separations and spacing.... \\
\hline nalcite in coal & 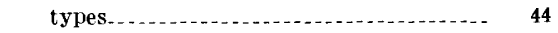 \\
\hline nalytic data, use of $\ldots$ & Coal, definition...... \\
\hline nkerite in coal & fibrous \\
\hline nnual rings. ............ & \\
\hline ite, shelly & nonbanded $\ldots$ \\
\hline of term & Coal balls \\
\hline ( & ion, minerals in coal \\
\hline lerent & for \\
\hline oal, definition & ration of, for observation. ..... $37-3$ \\
\hline pl. 14 & Coal layers, determination of \\
\hline 31,41 & methods of recording \\
\hline nces. & Coal observations, conditions for $\ldots \ldots \ldots 36-3$ \\
\hline & \\
\hline - $41-42$ & face \\
\hline aus material_._. & ck samples \\
\hline & es \\
\hline & $36,49,53-5$ \\
\hline & ( \\
\hline $29-33$ & $f_{2}$ \\
\hline 39 & in \\
\hline $\mathrm{rds}$ & pl. 1 \\
\hline $35-36$ & $\ldots 49,54-5$ \\
\hline$-35-36$ & ... 28, \\
\hline$-35-36$ & bands \\
\hline$-51,52$ & 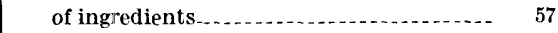 \\
\hline & e $\ldots \ldots \ldots$ pl. 22, \\
\hline & 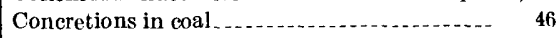 \\
\hline 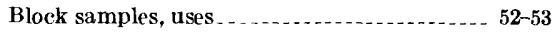 & ion \\
\hline 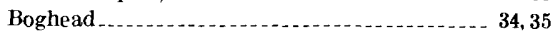 & - n \\
\hline $32-33$ & e \\
\hline 35 & (n) \\
\hline pl. 16,24 & ring \\
\hline pl. 22 & ation from \\
\hline 43 & 47,50, pl. 2 \\
\hline & \\
\hline & 43, pl. 1 \\
\hline - pl. 18 & $30,32-3$ \\
\hline 34,35 & $31-3$ \\
\hline 31 & \\
\hline p1. 17 & work \\
\hline, 15 & 44, pl. 2 \\
\hline & \\
\hline & \\
\hline & \\
\hline & ion \\
\hline & Field work, equipment for $\ldots \ldots \ldots$ \\
\hline 36 & Fish coal. \\
\hline hecking, in coal...... & ing .. \\
\hline
\end{tabular}




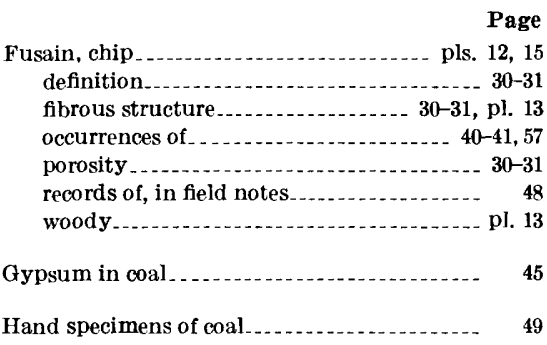

Impurities in coal _... _..... 32-33, 45, 48, pls. 17-20 Introduction . . . . . . . . 26-28 Isoetes spores . . . .

Jack 32-33

Jointing, vertical. See cleat.

Kaolinite in coal 45 , pl. 10,17

Kentucky coal pls. 15,18

Kolm 42 , pl. 22

Layers of coal, boundaries of measurements

Leaf coal 47, pl. 23

Lignite, attrital woody

Limonite in coal ........................ 45

pls. 11,12

Literature cited . . . . . . . . . . . . . . . . . $66-67$

Luster of coal .............................. 31, 41

Lycopsid megaspores.................... pl. 20

Marcasite in coal

45,46

Maryland coal

pl. 18

Measurements, records................... 39, 48

Melanterite in coal ......................... 45

Metamorphism, indicated by coal.......... 58-59

Michigan coal.......................... pl, 21, 24

Microbreccia............................ 46

Microfossils ............ 50

Microvitrain ........................... 29, pl. 21

Mineralization.................. 46-47, 58, pl. 15

Minerals in coal, authigenic................ 45-47

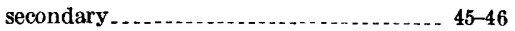

Moisture equilibration...................... 53-54

Nonbanded coal, description

North Carolina, natural coke

North Carolina coal

pl. 9,13

Ohio coal

pl. 6, 7, 9

Oil shale, distinguishing characteristics

Overburden

Paper coal 47

Parenchymatous tissue.................. pl. 15

Partings...................... 33, 48

Peacock coloration in coal................. 45

Peat, mineralized.......................... 46

Pennsylvania coal.
Pillar specimens of coal. See Coal sampling, column samples.

Pine needle coal .................... 47, pl. 23

Plant debris............ 31

Pollen grains . ........ 50, pl. 18

Porodendron . . . . . . . . . . 23

Precambrian coal ......................... pl. 24

Previtrain . . . . . . . 30, 42, 48, pl. 11

Pyrite in coal ....................... 45, 46, pl. 19

Quartz in coal ....................... 45, 46, pl. 11

Rank of coal, criteria for determining ........ 34

Rash. . .

Resinous needles. . . . . . . . . . . . . . . . . . . pl. 23

Resinous secretions in coal

Rhode lsland coal......... pl. 16

Rootlets... . . . . . .

Run-of-the-mine-coal.................. 49

Sampling. See Coal sampling.

Shipworm borings.......................... pl.

Slickensiede surface

Slip planes in coal.......... . . . . . . . . $44-45$

South Dakota coal................ pl. 21

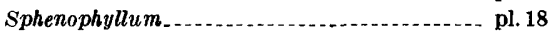

Spherulites in coal...................... 45

Splint.

Spore coals . . . . . . . . . . . . . . . . . . . . . . 34, pl. 21

Spore coats . . . . . . . . 34,35

Spores

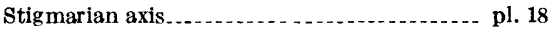

Structural history . . . . .

Sulfur balls.............. 51

Sulfur in coal.............................. 59

Tennessee, carbonaceous shale $\ldots \ldots \ldots$ pl. 19

Teredo _ . . . . .

Terminology, definitions.................. 29-26

problems .............................. 28

Texture of coal ........... $41-42$

Thickness, characteristics................. 56 of bands. . . 39,48

Tools for fieldwork . . . . . . . .

Tree stump, vertical in lignite _.............. pl. 12

Values, mineral-matter-free

Vesicular texture

Vitrain, concentration and mapping ........ 57 definition . . occurrences of . $39-40$ records in field notes. woody _. . . . . . . . . . 10

Volatile matter ............. $31,34,35$

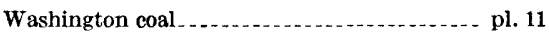

Water, excess, in cores.................... 53-54

Weathering, effect on coal ............ 36,47

West Virginia coal _ _...... 8

Wood, grain of 


\section{PLATES 6-24}


PLATE 6

BANDED BITUMINOUS COAL, STEUBENVILLE SHAFT, EASTERN OHIO

Top layer dominantly attrital (at), dull luster; central layer moderately thin- and medium-banded, containing vitrain (v), attrital matrix midlustrous; basal centimeter shaly and impure $(\mathrm{im})$. Negative $1075, \times 0.71$. 


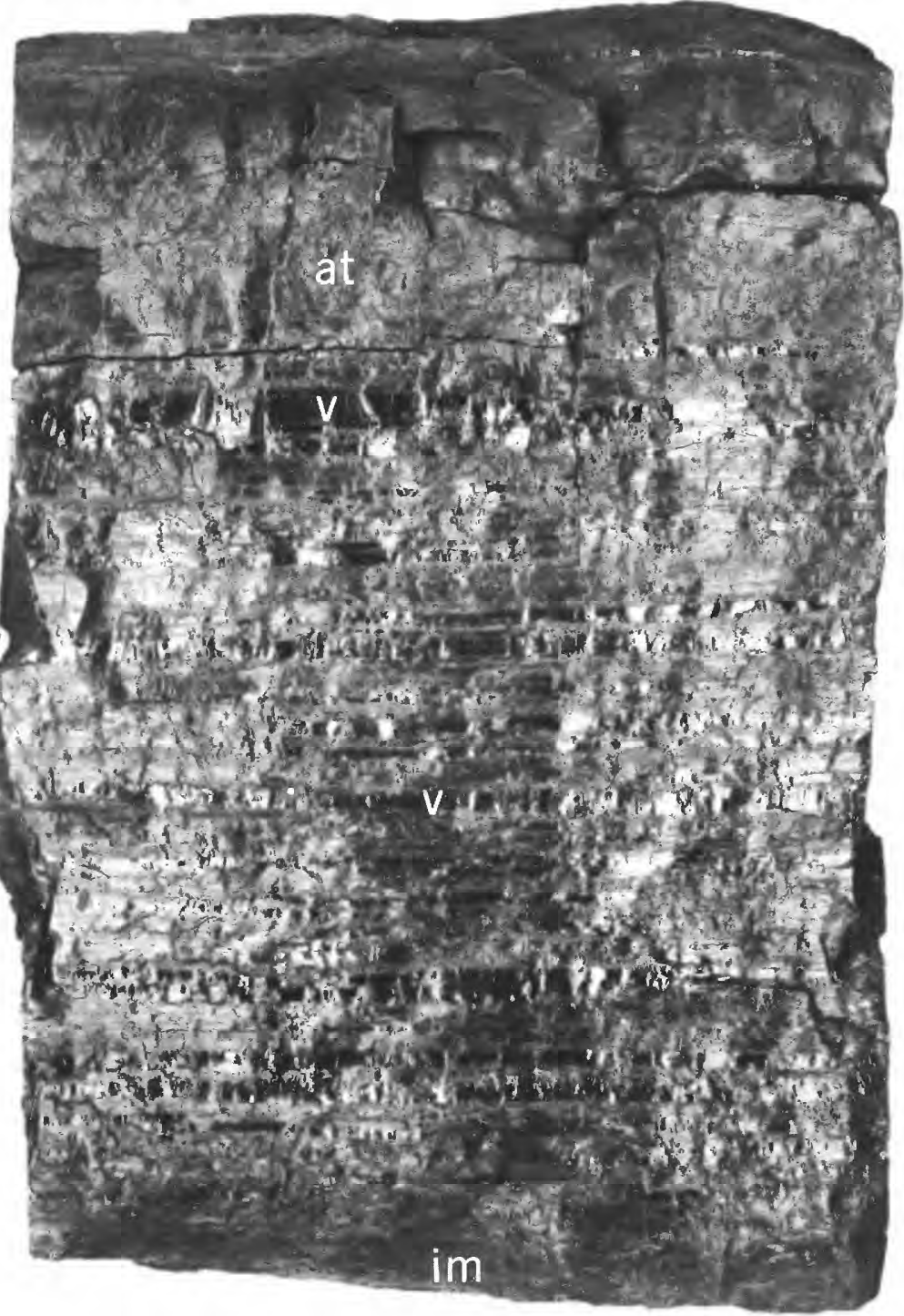

BANDED BITUMINOUS COAL, STEUBENVILLE SHAFT, EASTERN OHIO 

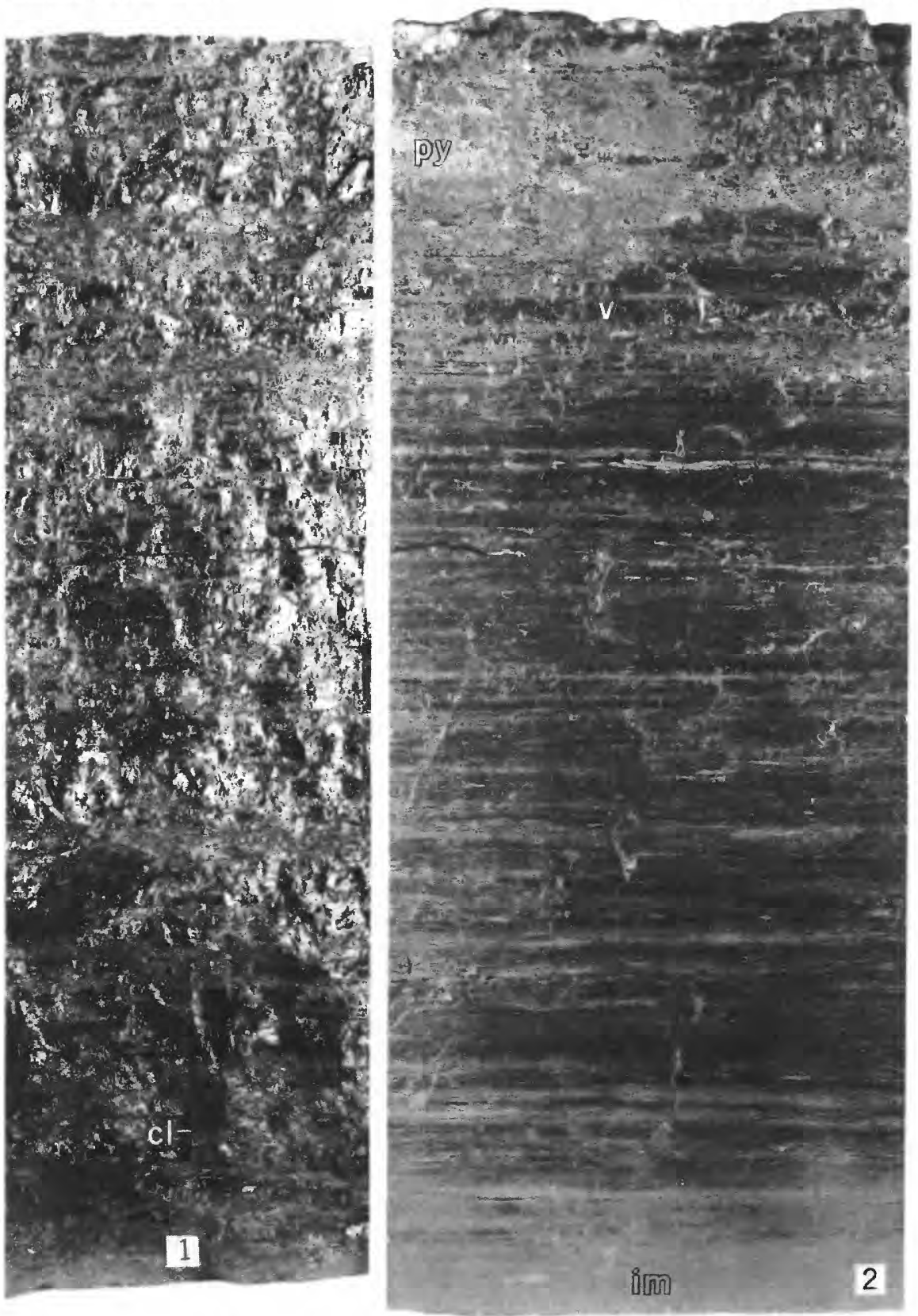

BANDED BITUMINOUS COAL, MEIGS CREEK BED NEAR CADIZ, EASTERN OHIO 


\section{PLATE 7}

\section{BANDED BITUMINOUS COAL, MEIGS CREEK BED NEAR CADIZ, EASTERN OHIO}

Frgure 1. Butt cleat, normal to the major cleat surface $(c l)$; rough. Negative $1106, \times 0.67$.

2. Same block as in figure 1, showing face cleat, normal to the minor cleat surface; relatively smooth. Upper left shows a nodular aggregation of secondary pyrites $(p y)$, also illustrated at low magnification on plate 19, figure 1. This coal is mostly sparsely thin banded, matrix with moderately bright luster. The duller luster of the surface in figure 2 is a result of the cleat plane. Impure coal $(\mathrm{im})$. Negative $1107, \times 0.69$. 


\section{PLATE 8}

\section{BANDED BITUMINOUS COAL, BAKERSTOWN BED NEAR NEWBURG, PRESTON COUNTY, W. VA.}

Figure 1. Butt cleat, normal to the major cleat surface, very closely cleated; upper part moderately thin and medium banded; lower part sparsely thin banded; attrital matrix with medium luster. Negative 1103, $\times 1.15$.

2. Same specimen as in figure 1, face cleat, normal to the minor cleat surface, showing surfaces of the major cleat system. Negative $1102, \times 0.95$.

3. Enlargement of part of the area shown in figure 1. Negative 1089, $\times 2.70$.

4. Enlargement of part of the area shown in figure 2, but lighting is changed to reflect light from surfaces of the major cleat $(\mathrm{cl})$ system. Vitrain $(v)$. Negative $1088, \times 2.10$. 

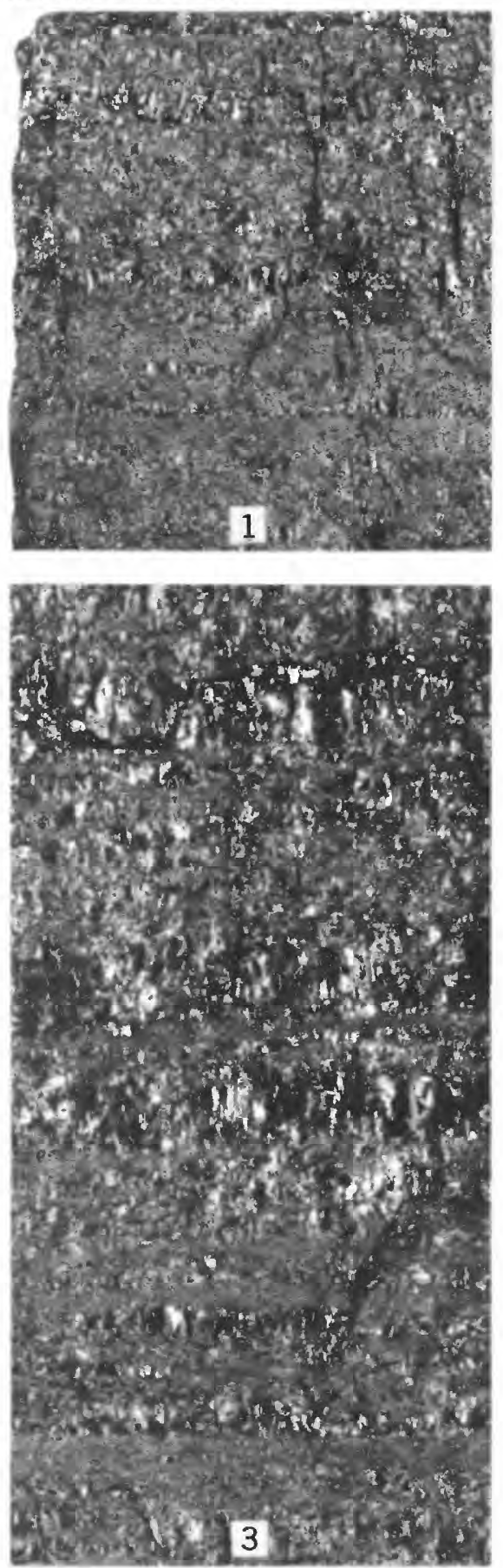
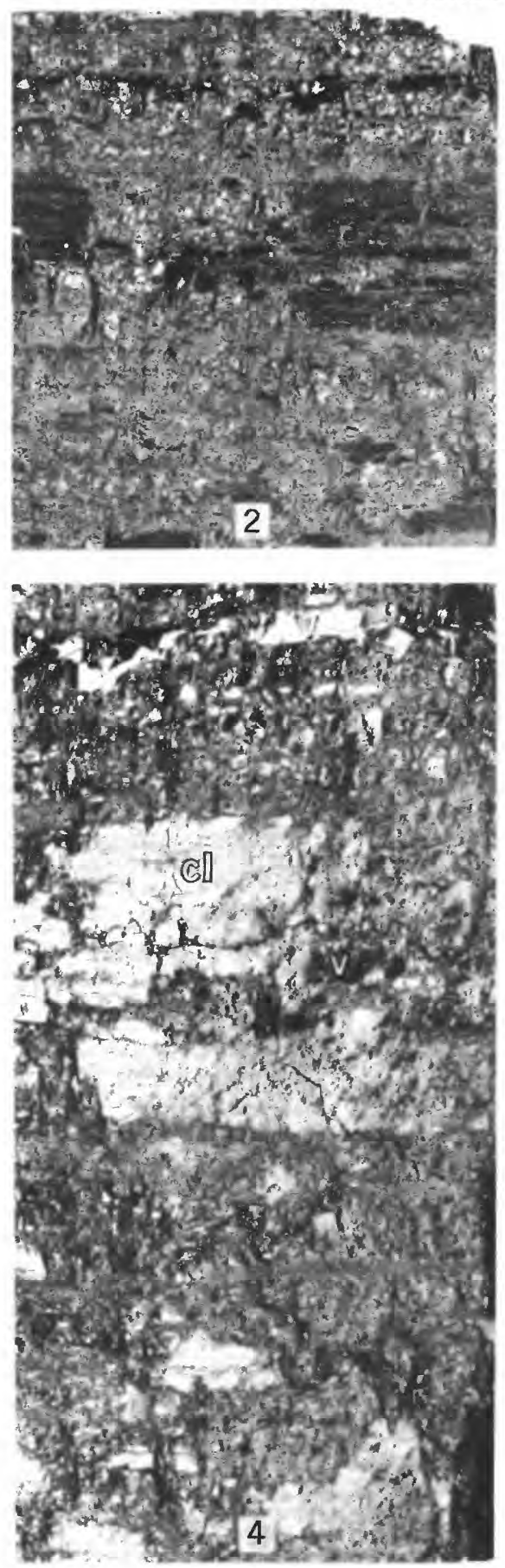

BANDED BITUMINOUS COAL, BAKERSTOWN BED NEAR NEWBURG, PRESTON COUNTY, W. VA. 


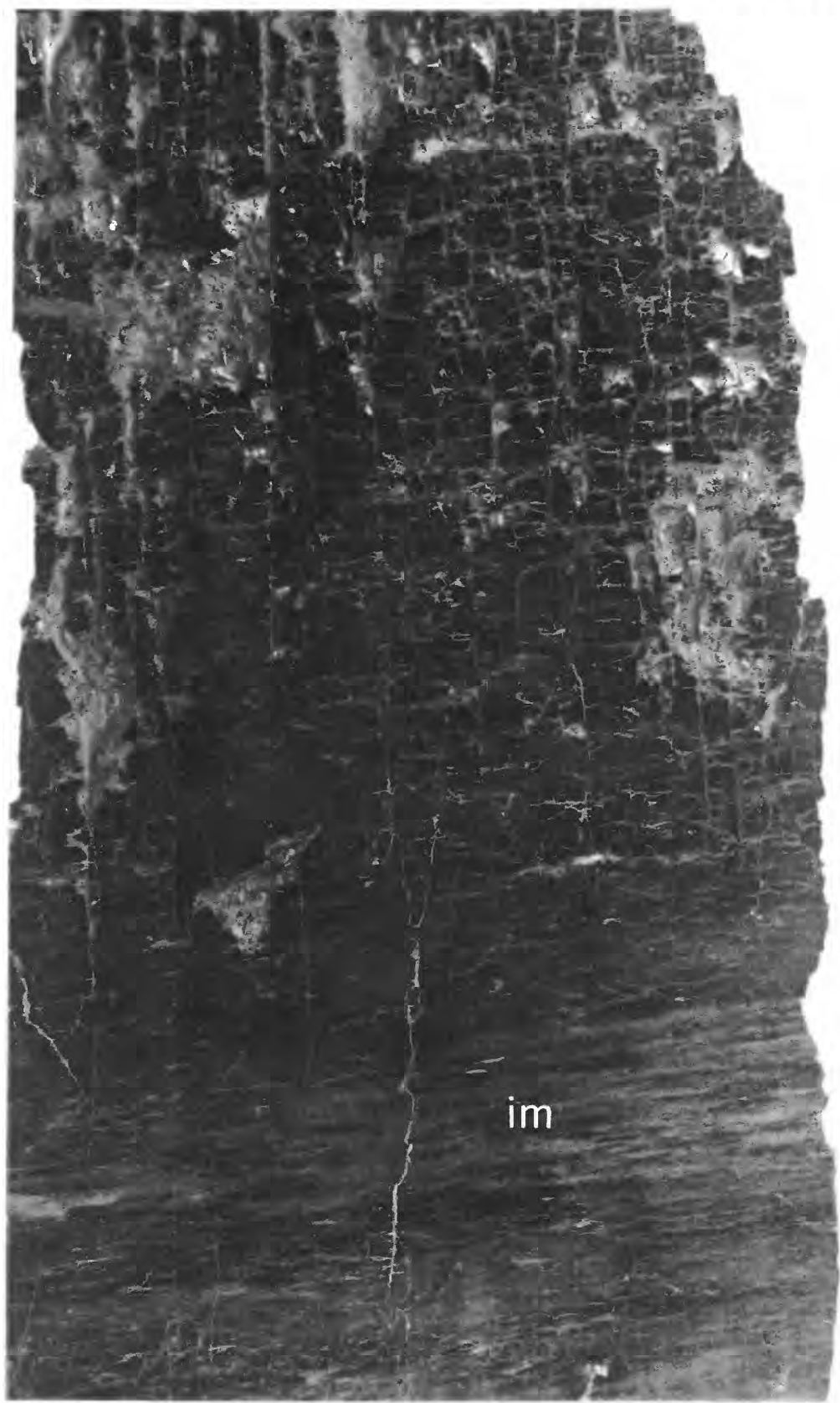

BANDED BITUMINOUS COAL, CUMNOCK BED, DEEP RIVER COAL FIELD NEAR SANFORD, CHATHAM COUNTY, N. C. 
PLATE 9

BANDED BITUMINOUS COAL, CUMNOCK BED, DEEP RIVER COAL FIELD NEAR SANFORD, CHATHAM COUNTY, N.C.

Surface lightly polished, showing highly cleated bright luster coal above, and much more sparsely cleated, impure coal below. The impure coal (im) forms a layer scarcely definite enough to regard as a parting but, when mined, material from such a layer will remain in large lumps so that it can be easily removed from the commercial product. Negative 1101, $\times 1.19$. 
PLATE 10

\section{BITUMINOUS AND SUBBITUMINOUS COAL}

Figure 1. Banded bituminous coal, Bay City, Bay County, Mich. Horizontal fracture surface showing strong parallelism of major cleating, cleat $(c l)$ separations occupied by secondary kaolinite. Vitrain (v) and attrital coal (at). Negative 1063, $\times 1.10$.

2. Face, slightly enlarged, normal to major plane of eleating, of a part of the same specimen shown in figure 1. Coal ranges from sparsely (below) to moderately (above) thin banded. Cleat $(c l)$ and secondary cleat mineralization fades out below the vitrain $(v)$ layers at the top. Negative $1074, \times 2.08$.

3 . Very thick woody vitrain lens associated with western subbituminous coal, probably from Wyoming; exact source unknown. No minor cleating is visible from this surface, which probably corresponds in part to the major cleat plane. Broad conchoidal fracture is clearly evident, but the structure of annual rings of the wood is also visible in lower and right-hand areas in the picture. Negative $1122, \times 1.14$. 

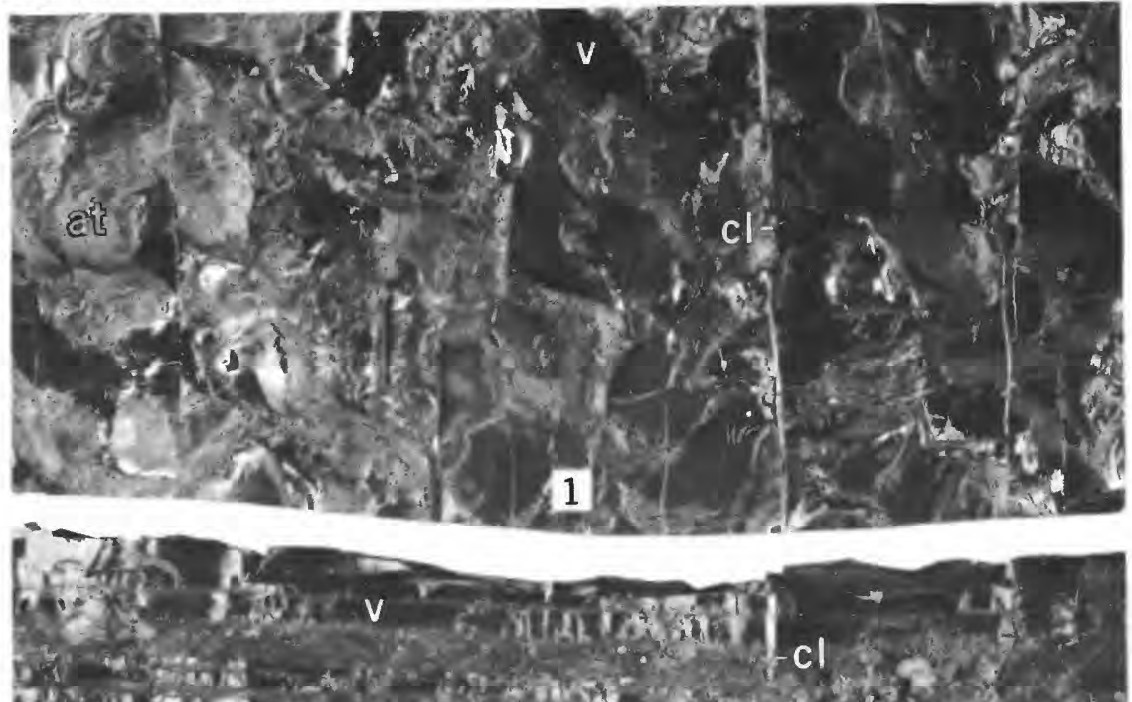

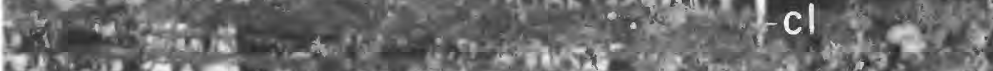

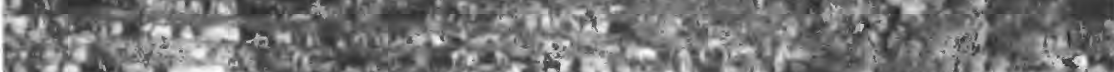
8.

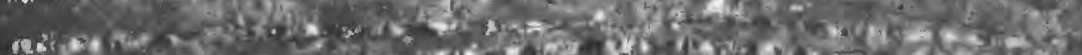
Fow 8 \% स. if
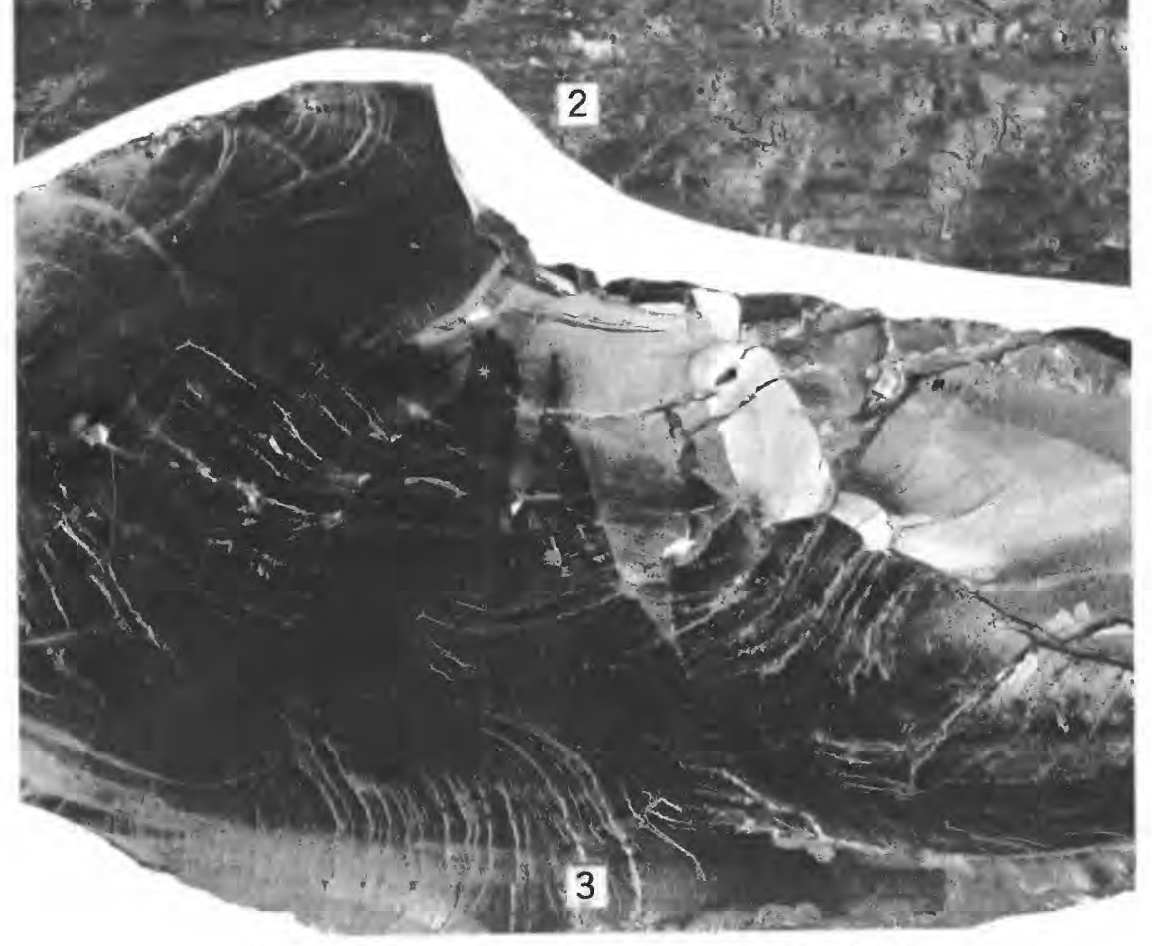

BITUMINOUS AND SUBBITUMINOUS COAL 
GEOLOGICAL SURVEY
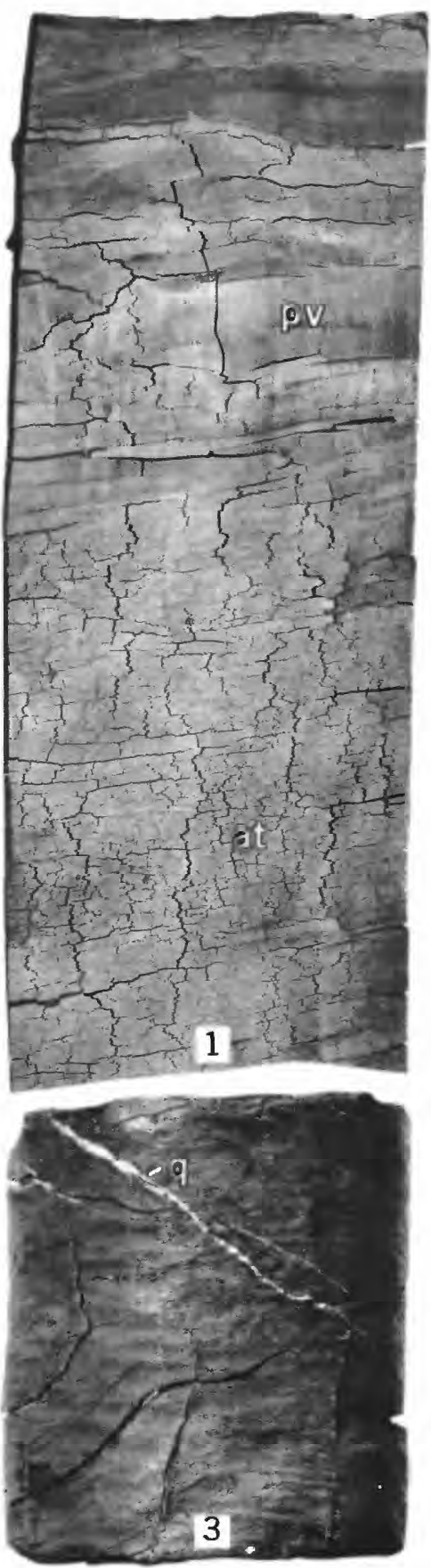

BULLETIN 1111 PLATE 11

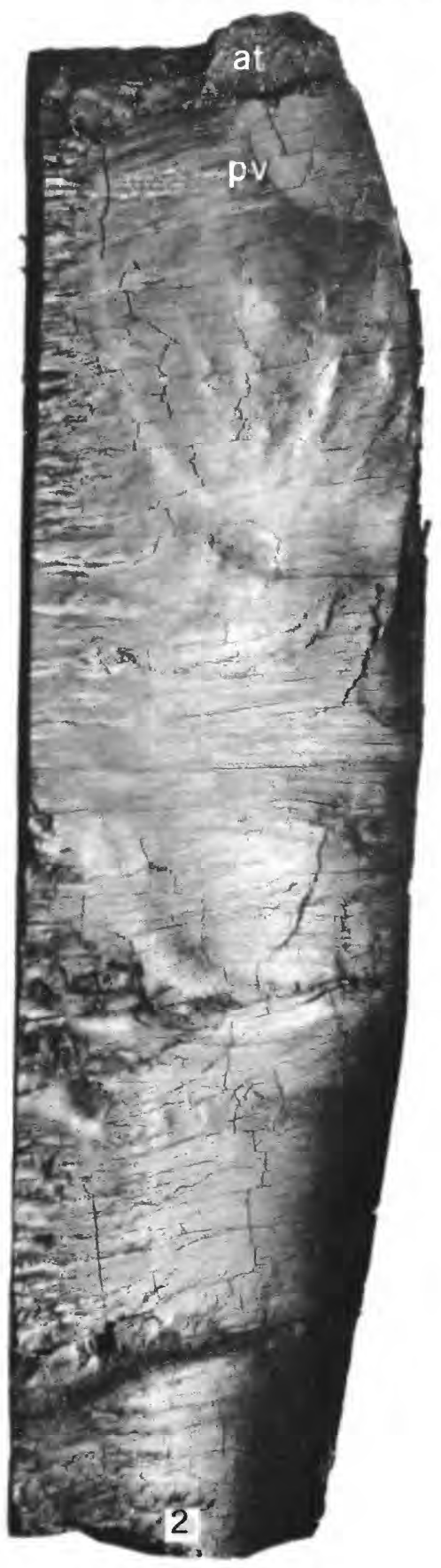

LIGNITIC COAL 


\section{PLATE 11}

\section{LIGNITIC COAL}

FIgURe 1. Saw cut surface, partly dried, of woody previtrain ( $p v$ ) and attrital (at) lignite core from the Toledo lignite area, Lewis County, Wash. (See Fieldner and others, 1939.) Note the difference between desiccation cracks and cleat shown in illustration of higher rank coal. Negative 1155-1, $\times 0.88$.

2. Longitudinal fracture surface of very thick woody previtrain layer $(p v)$ from a core taken in same area as figure 1. Striation is nearly all a result of grain of the wood. Some cracks are present owing to slight drying of the surface. Negative $1158-1, \times 0.91$.

3 . Outer surface of a woody lignite core taken in the same area as figures 1 and 2. See also plate 15, figure 3. Desiccation cracks tend to follow grain of wood. A thin vein of chalcedonic quartz $(q)$ cuts diagonally across the specimen. Negative $1164, \times 0.88$. 


\section{PLATE 12}

\section{FUSAIN; UNCOMPRESSED WOODY LIGNITE}

Figure 1. Lens of chip fusain from Lower(?) Kittanning bed, New Bethlehem, Armstrong County, Pa. See also plate 13, figure 1. Chips of woody fusinized plant fragments are prevalent; this lens is coherent because of disseminated secondary mineralization. Negative 1083, $\times 0.98$.

2. Woody lignite from vertical tree stump cut by core in Toledo lignite area, Lewis County, Wash. See also plate 11, figure 2. Cracks in wood filled by tuffaceous clay. Coal is brown (not black), and its fibrous appearance evidently is due to the ability to withstand vertical compression when oriented in a vertical position, rather than to fusinization. Negative 1161, $\times 0.81$. 


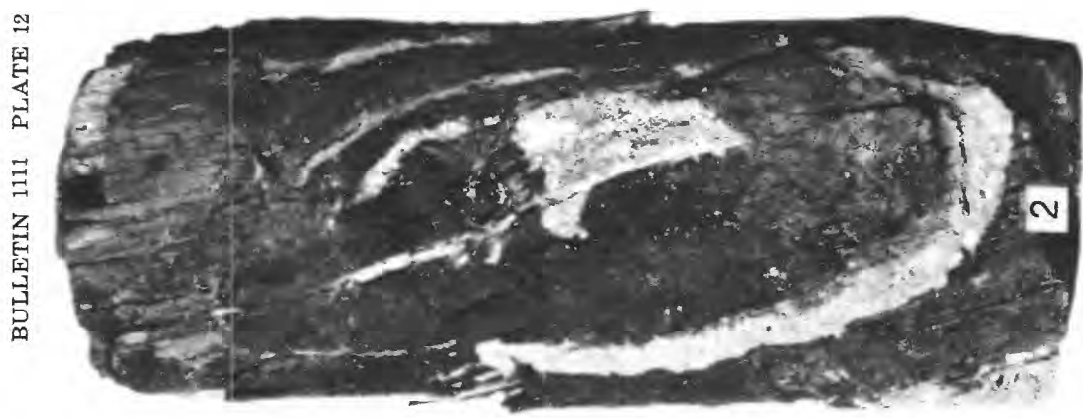

年

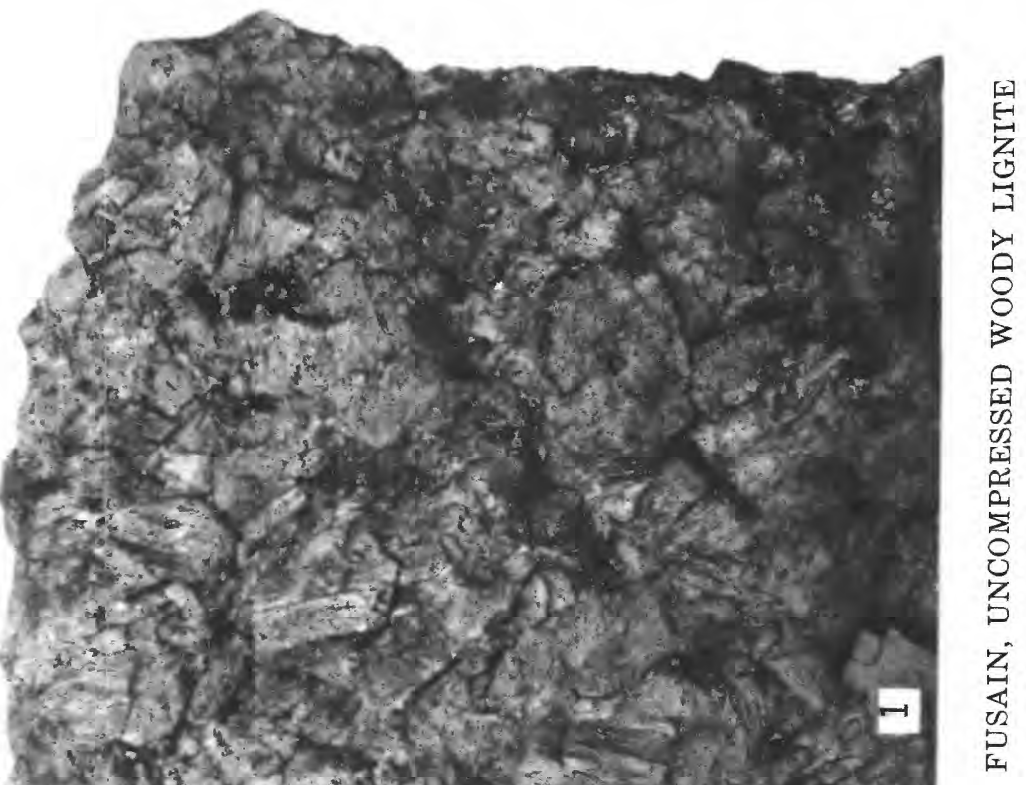
40 .

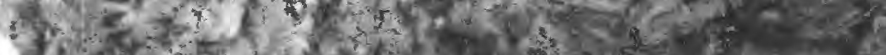

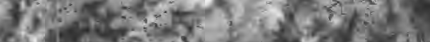
2.

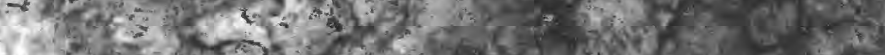

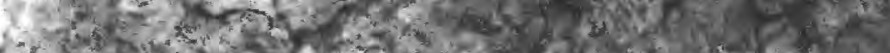

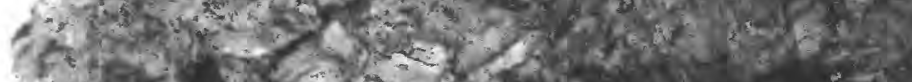
(3) 


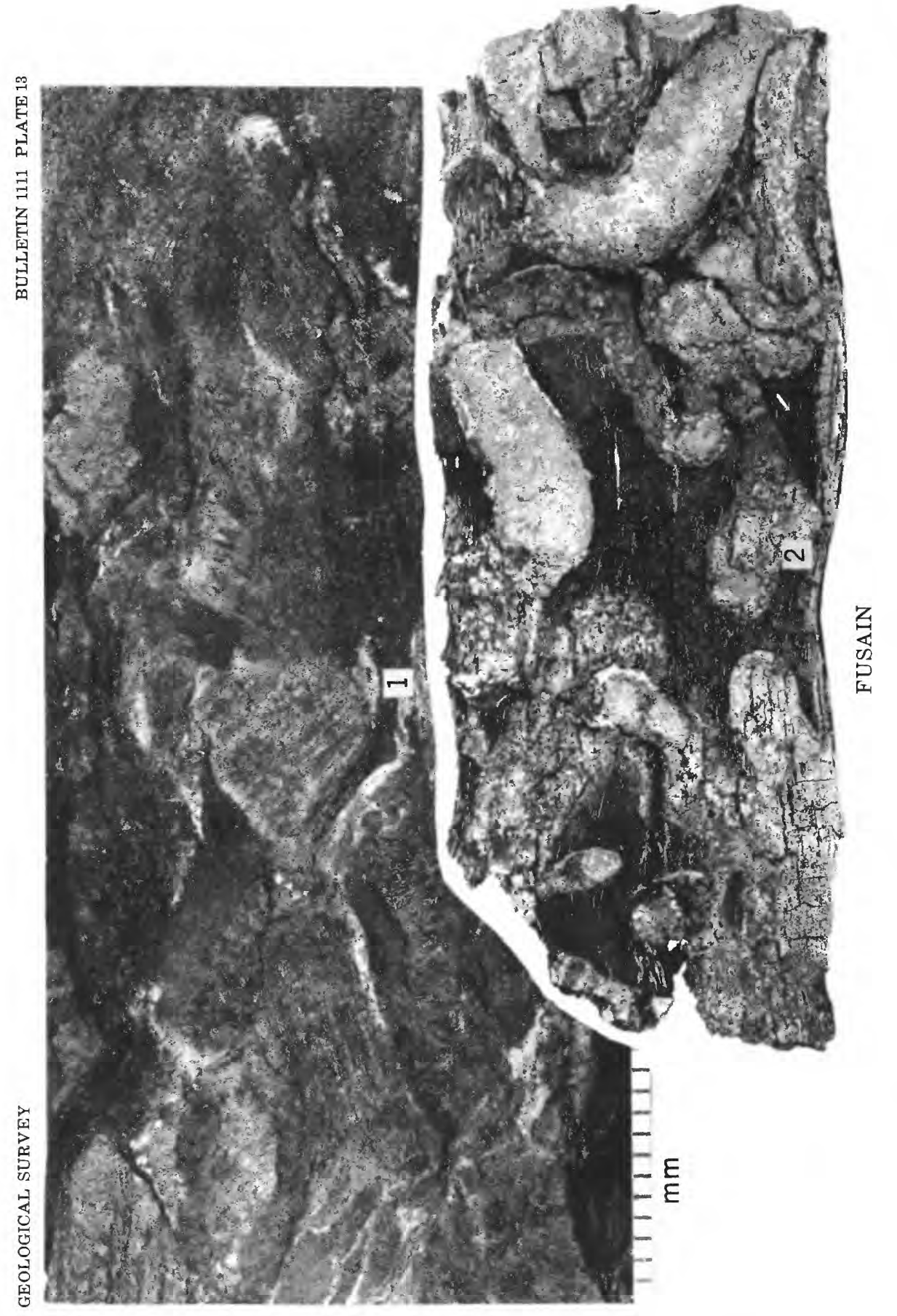




\section{PLATE 13}

\section{FUSAIN}

Figure 1. Surface, at slight enlargement, of vertical cut through lens of chip fusain shown on plate 12, figure 1. Note the fibrous character of chips derived mostly from woody cortical tissue; light-colored areas are chiefly a result of secondary pyritic and kaolinitic cell filling. Negative $1072 b, \times 2.91$.

2. Woody fusain fragment with shipworm borings, collected by J. E. Johnston, U.S. Geological Survey, from Black Creek formation (Upper Cretaceous), near Goldsboro, Wayne County, N.C. Borings, excavated by Teredo, the shipworm, are filled with pyritic silty sandstone of the marine deposit. Teredo, restricted to brackish and marine environments, derives nutriment from wood cellulose, which is not present and only represented by an alteration product in fusain. The wood evidently was floated into a marine environment and attacked by Teredo before conversion into fusain. Negative 1126, $\times 1.43$. 


\section{PLATE 14}

\section{FUSAIN}

Figure 1. Normal distribution of fusain lenticles in banded bituminous coal. Photographed at slight enlargement on rough-cut, sawed surface; slightly turned so that only the fusain lenticles $(f)$ and cavities are nonreflecting. Vitrain (v); attrital coal (at). Negative 1078b, $\times 1.48$.

2. Part of specimen shown in figure 1 at slightly greater enlargement. Fusinized fragments that chance to be cut more or less in accord with the longitudinal grain of the tissues appear fibrous. Note that fragments of fusinized tissues are present in very thin as well as thicker lenticles and that they also contribute to attrital coal (at). Negative $1092, \times 2.67$. 
焉
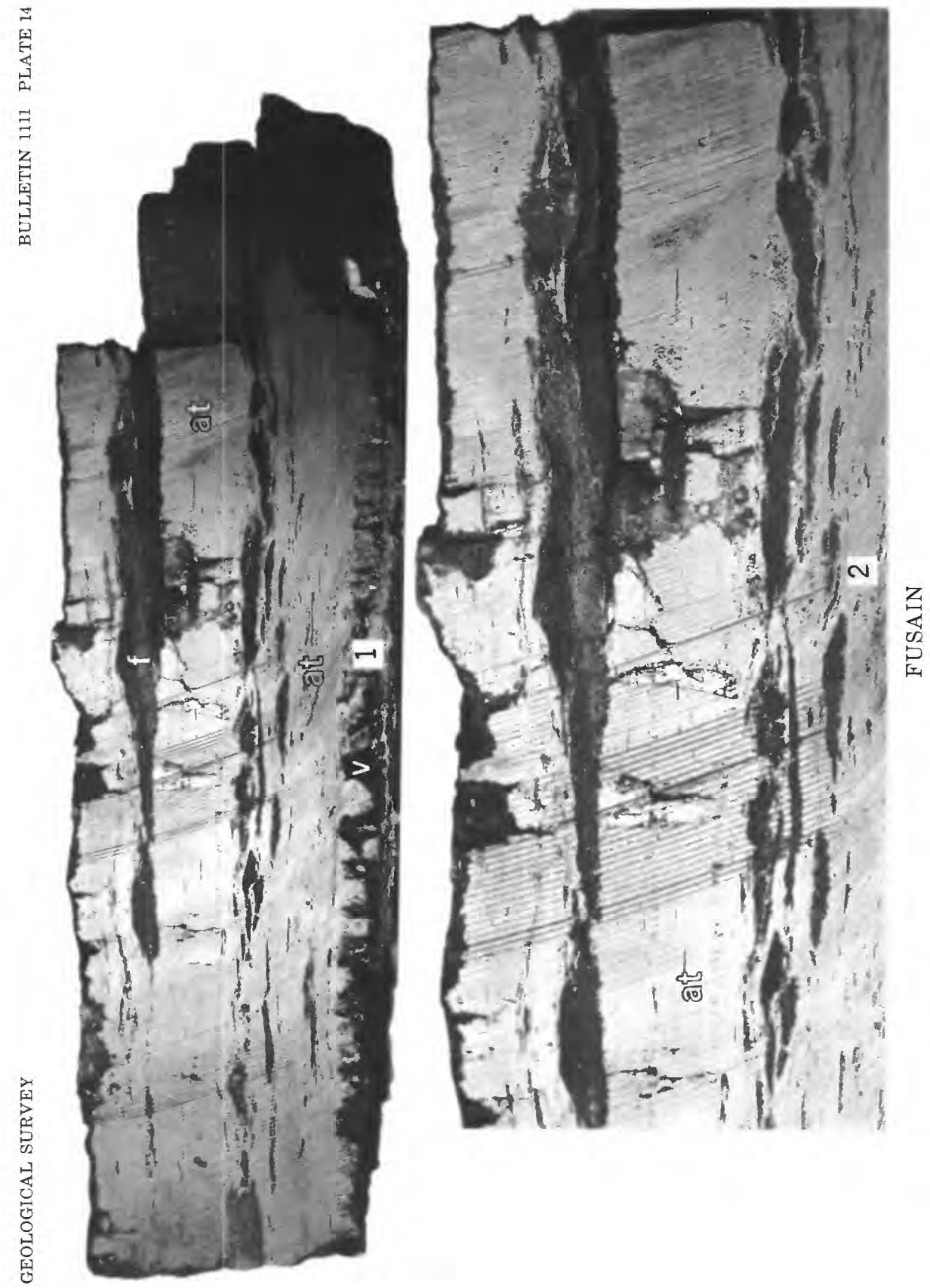


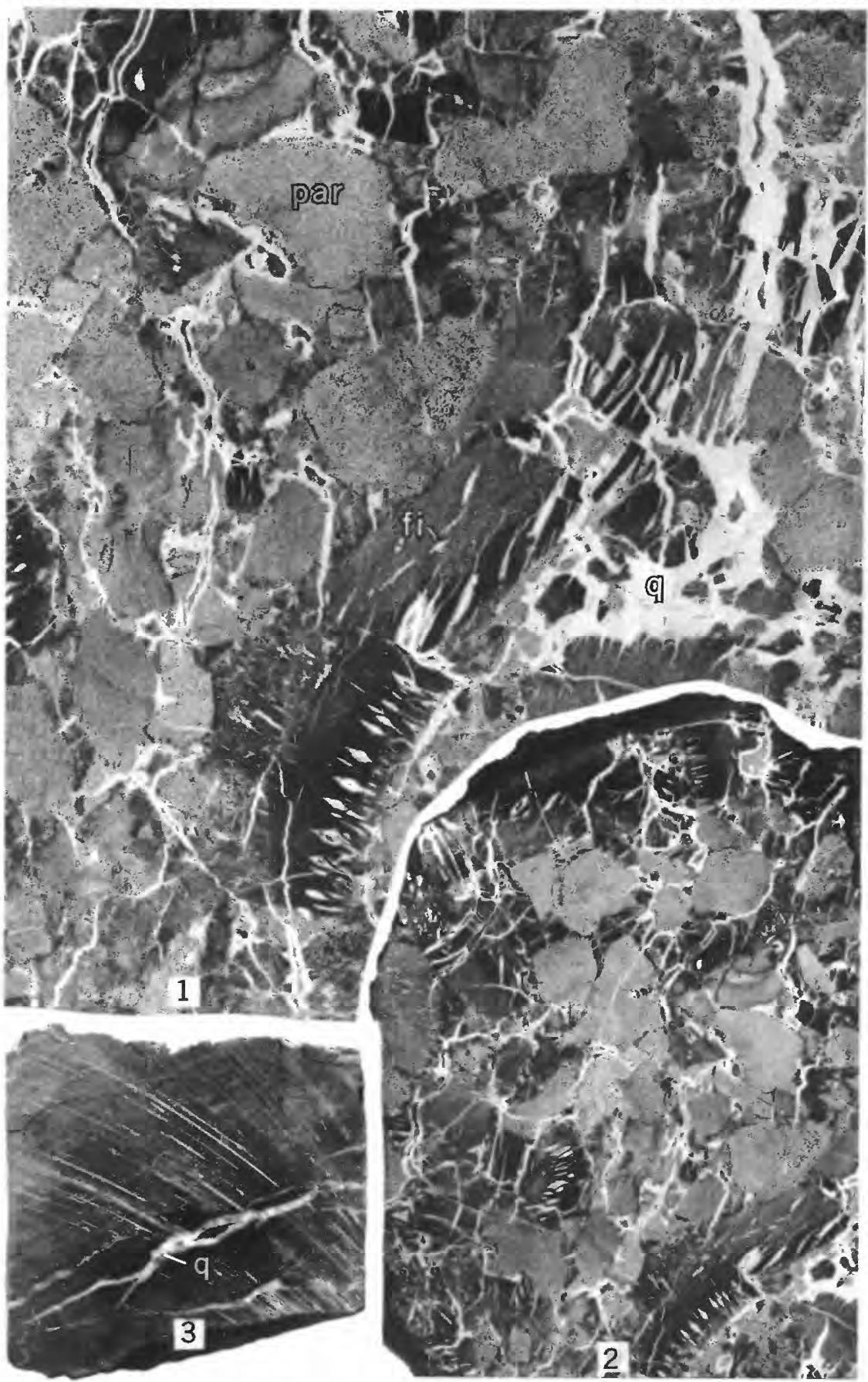

SILICEOUS MINERALIZATION 


\section{PLATE 15}

\section{SILICEOUS MINERALIZATION}

Figure 1. Silicified pocket of chip fusain, somewhat enlarged, from Princess No. 5 coal, Kenova district, eastern Kentucky. A variety of types of fusinized tissues are included from fibrous fragments $(f i)$ to parenchymatous cortical pieces (par). In a nonmineralized occurrence the parenchymatous tissues would be crushed to an irrecognizable powder and only fibrous fragments would persist as chips and be easily recognized. Both quartz crystals $(q)$ and chalcedony are present in the white veinlets, but the principal mineralization is chalcedonic. Surface was prepared by smooth grinding followed by hydrofluoric-acid etching; photographed when dry. Negative $1091, \times 1.94$.

2. Specimen from which figure 1 was obtained, photographed nearly natural size. Negative $1090, \times 0.97$.

3. Chalcedonic and quartz veinlets $(q)$ on rough, saw cut surface of core of woody lignite, Toledo lignite area, Lewis County, Wash. See also plate 11, figure 3 . Negative $1154, \times 0.88$. 


\section{PLATE 16}

\section{SILICEOUS MINERALIZATION}

Figure 1. Breccia of coal and coaly shale fragments in siliceous matrix, at slight enlargement, from Leyden mine near Golden, Jefferson County, Colo. Surface prepared by smooth grinding, followed by etching in hydrofluoric acid. Greater brilliance was obtained by covering the surface with a layer of cellulose nitrate lacquer and then photographing when dry. Yellowish discoloration, associated with cracks and veinlets, probably represents the oxidation products of uranium minerals since this specimen is somewhat radioactive and the Leyden mine site is noted as one of the first from which uranium was reported in this country. The extensive microbrecciation is much less evident on rough fracture surfaces than on the prepared surface shown here. Negative $312 \mathrm{a}, \times 2.73$.

2, 3. Specimens from Leyden mine prepared as in figure 1, photographed nearly natural size. A part of figure 3 corresponds to that shown in figure 1. Negative 311a, $\times 1.04$.

4. Quartz vein $(q)$ in Rhode Island meta-anthracite and dark shale cut by drill core. (See Toenges and others, 1948.) The dark material at the base (meta), much slickensided and graphitic, probably is impure coal. Negative $1167, \times 1.22$. 


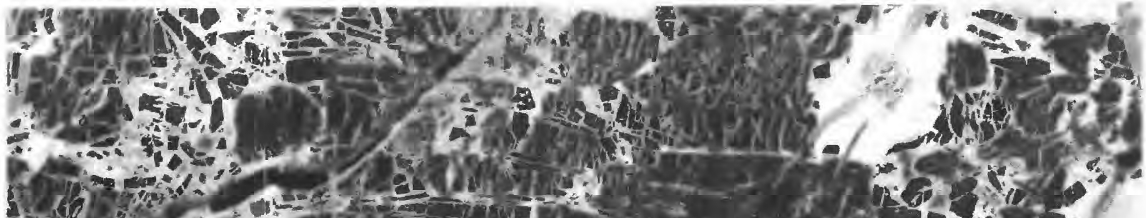

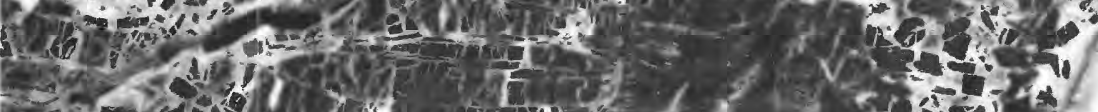

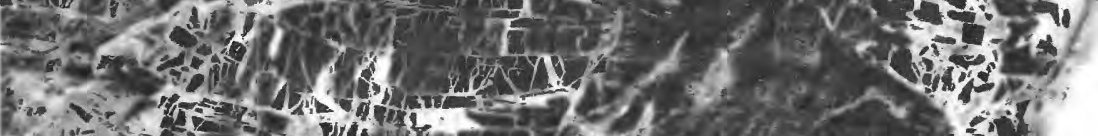

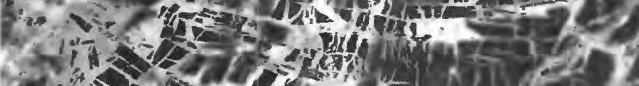
2.

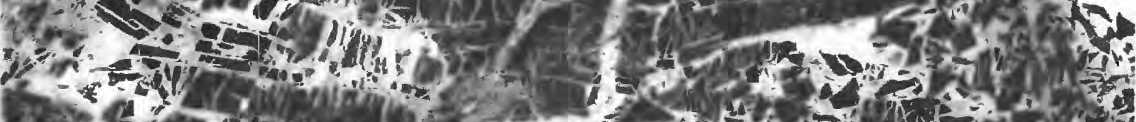

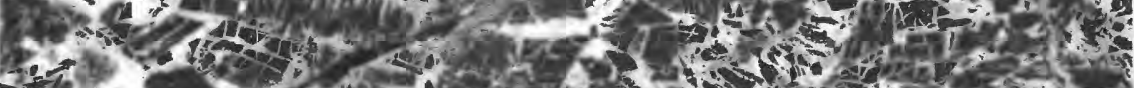

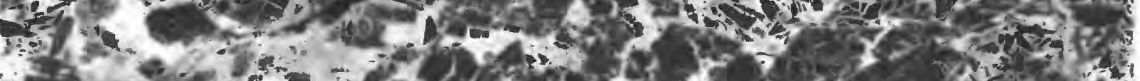

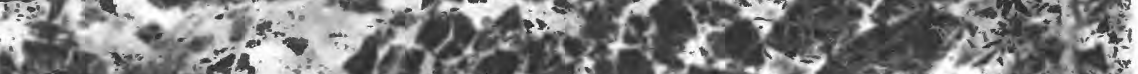

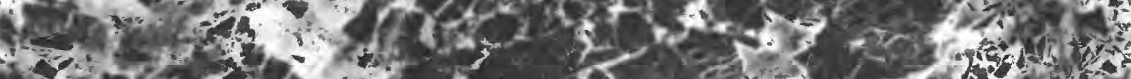

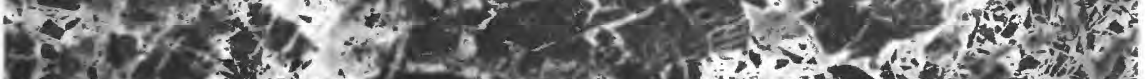

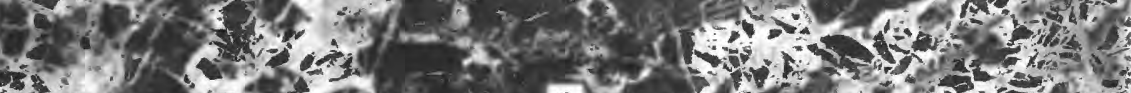

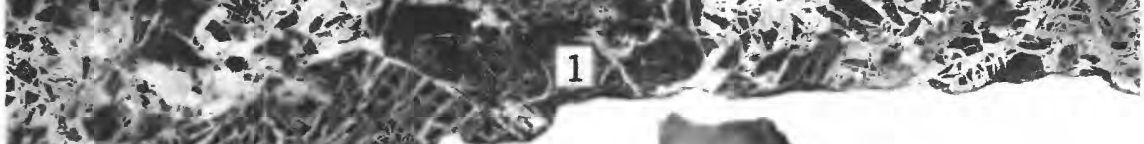

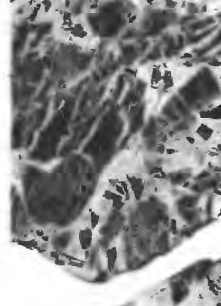
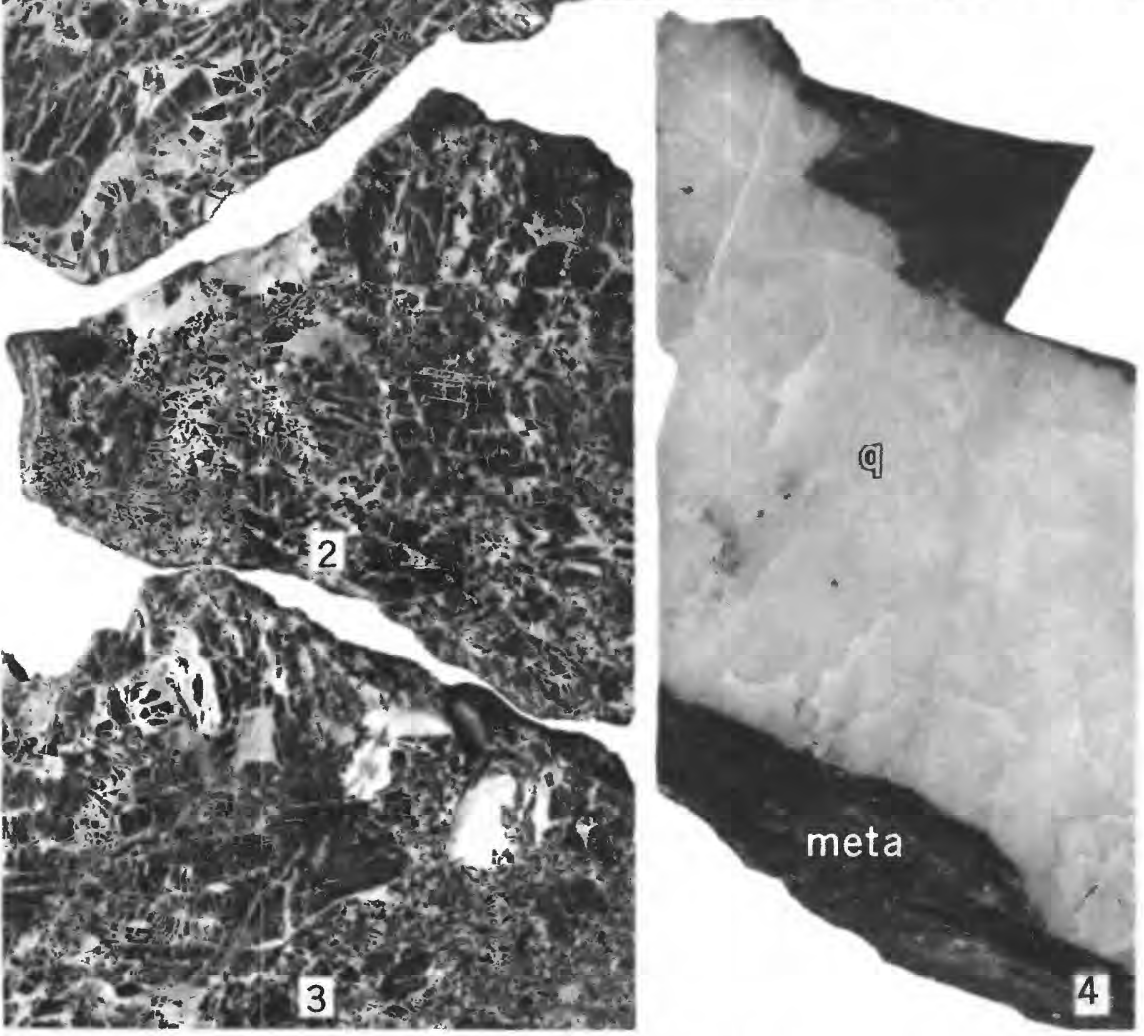

SILICEOUS MINERALIZATION 


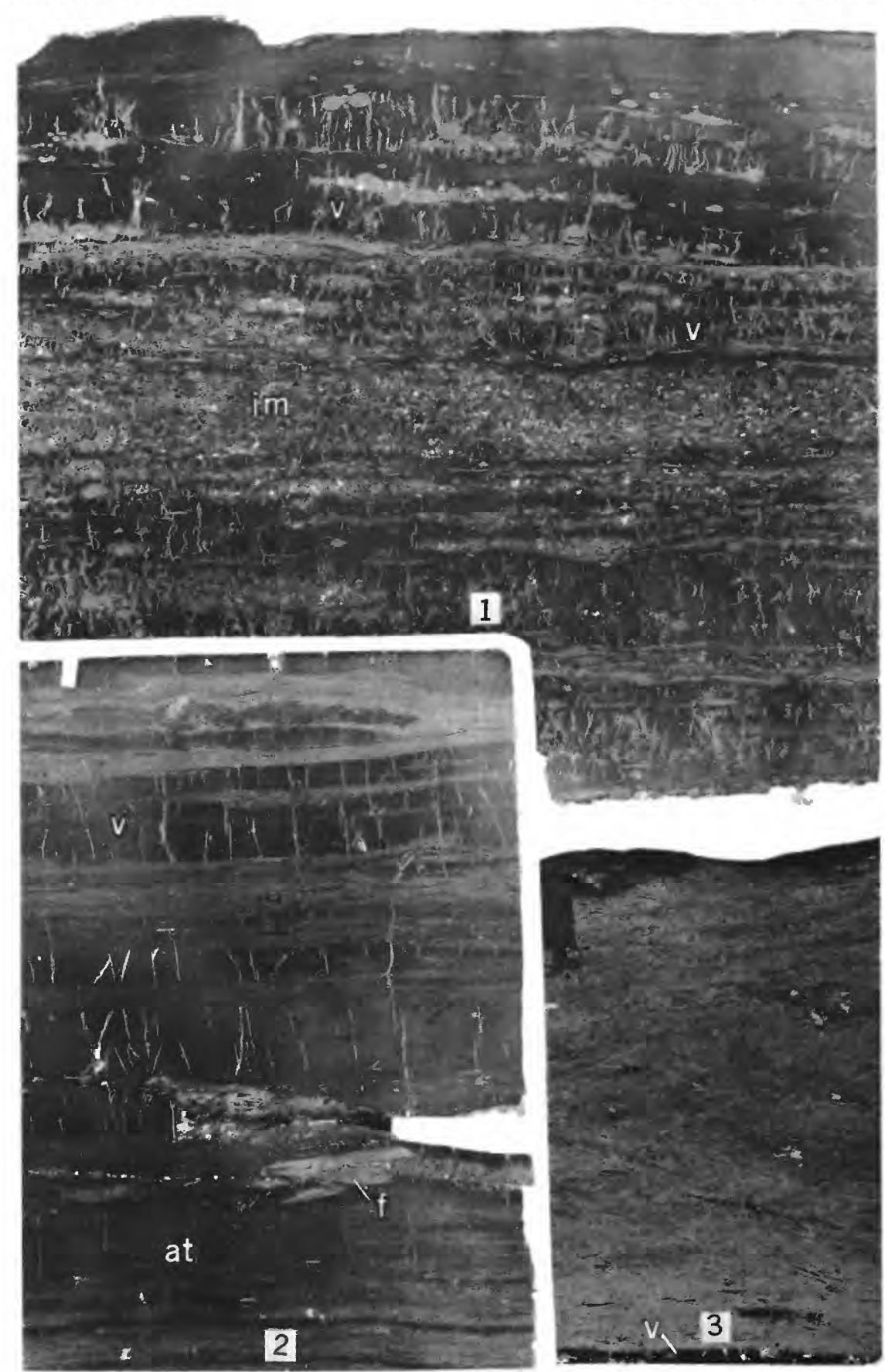

HIGH-RANK IMPURE COAL AND CARBONACEOUS SHALE 


\section{PLATE 17}

\section{HIGH RANK IMPURE COAL AND CARBONACEOUS SHALE}

Figure 1. Polished surface of anthracite refuse associated with Buck Mountain coal bed, near Mount Carmel, Northumberland County, Pa. Illumination at a low angle in this photograph; dark layers represent much cleated vitrain bands (v) that show specular brilliance if they are illuminated at a higher (critical) angle. Cleat is strongly mineralized with kaolinite and siderite. Spheroidal areas represent sideritic spherulites that leave small rounded depressions ("pock marked" coal) on weathered surfaces. Bedded impurity $(\mathrm{im})$ in central layer is mostly hard clay. Negative $1111, \times 2.60$.

2. Polished surface of banded anthracite, photographed with illumination from a low angle, from No. 10 bed, near Shamokin, Northumberland County, Pa. Vitrain bands $(v)$ have thin kaolinite cleat facings, fusain lenticles $(f)$, and attrital coal (at) showing the same relations as in beds of banded coal of lower rank. Negative $1112, \times 2.04$.

3. Carbonaceous shale associated with low-volatile coal at Worlds End State Park, near Forksville, Sullivan County, Pa. Such shales often include disseminated pyrite, thin streaks of vitrinized tissue (v), cleated as in coal beds, and small fusinized fragments that are noncleated. Surface photographed was ground smooth and etched with hydrofluoric acid. Negative $1123, \times 1.75$. 


\section{PLATE 18}

\section{COAL BALLS AND CALCAREOUS IMPURITY}

Figure 1. Interior surface of a coal ball, about half size, from near Hyden, Leslie County, $\mathrm{Ky}$. Coal balls, rare in eastern coal fields, usually consist of concretionary deposits of calcite formed within a peat layer; surrounding peat was later compressed around the concretion to become coal, so that the calcareous nodules now occur in coal beds. The peaty material within the coal-ball concretion maintains its original relations as shown here. The surrounding coal $(c)$ adheres in patches on the outside; here a large stigmarian axis (stig axis) is preserved in outline and filled with variously rotted debris, except at the lower edges, shows rootlets $(r t)$ attached there and following a diverging sinuous course within the peat. Clear open areas within the roots are normal; in the coal ball they are solidly occupied by clear calcite $(c a)$. In addition to very finely divided vegetable debris, the petrified coal-ball "peat" includes calamite (cal) and Sphenophyllum (sph) stems. Regarded as an impurity by miners, coal balls constitute an important source of information about the vegetable material that elsewhere became converted into coal. Negative 163, photograph by J. R. Gill, $\times$ 0.58 .

2. Pollen grain from calcareous coal ball, highly magnified, same source as figure 1. Pollen in uncompressed condition is preserved among the fine debris in calcareous coal-ball concretions. Living contents originally occupied the central body shown in the figure, and the surrounding area constitutes an air bladder (cut across in section) that aided wind dispersal. Pollen grains can be identified to aid in correlation of coal deposits. Negative 208-26, $\times 214$.

3. Pollen grain, similar to that in figure 2 , showing attachment of central body to reticulate bladder membrane. Negative 208-26, $\times 214$.

4. Cross section of part of a small calamite twig, highly magnified to show preservation of delicate tissue detail, in calcareous coal ball from same source as figure 1. From center outward the pith, wood, cambium (camb) or growing layer, and cortex (cort) or thin bark is shown. Secretory ducts (sec) with resinous contents are present in the bark of this plant. All cells and the central area are filled with calcite $(c a)$. Negative 282-21, $\times 100$.

5. Coal core split to show calcite (ca) facing along major cleat plane in banded high-rank coal of Georges Creek basin, Allegany County, Md. (See Toenges and others, 1949.) Such facings represent deposits of secondary minerals that fill the cleat cavities that formed after coal had been consolidated. Negative 1159-1, $\times 0.89$. 


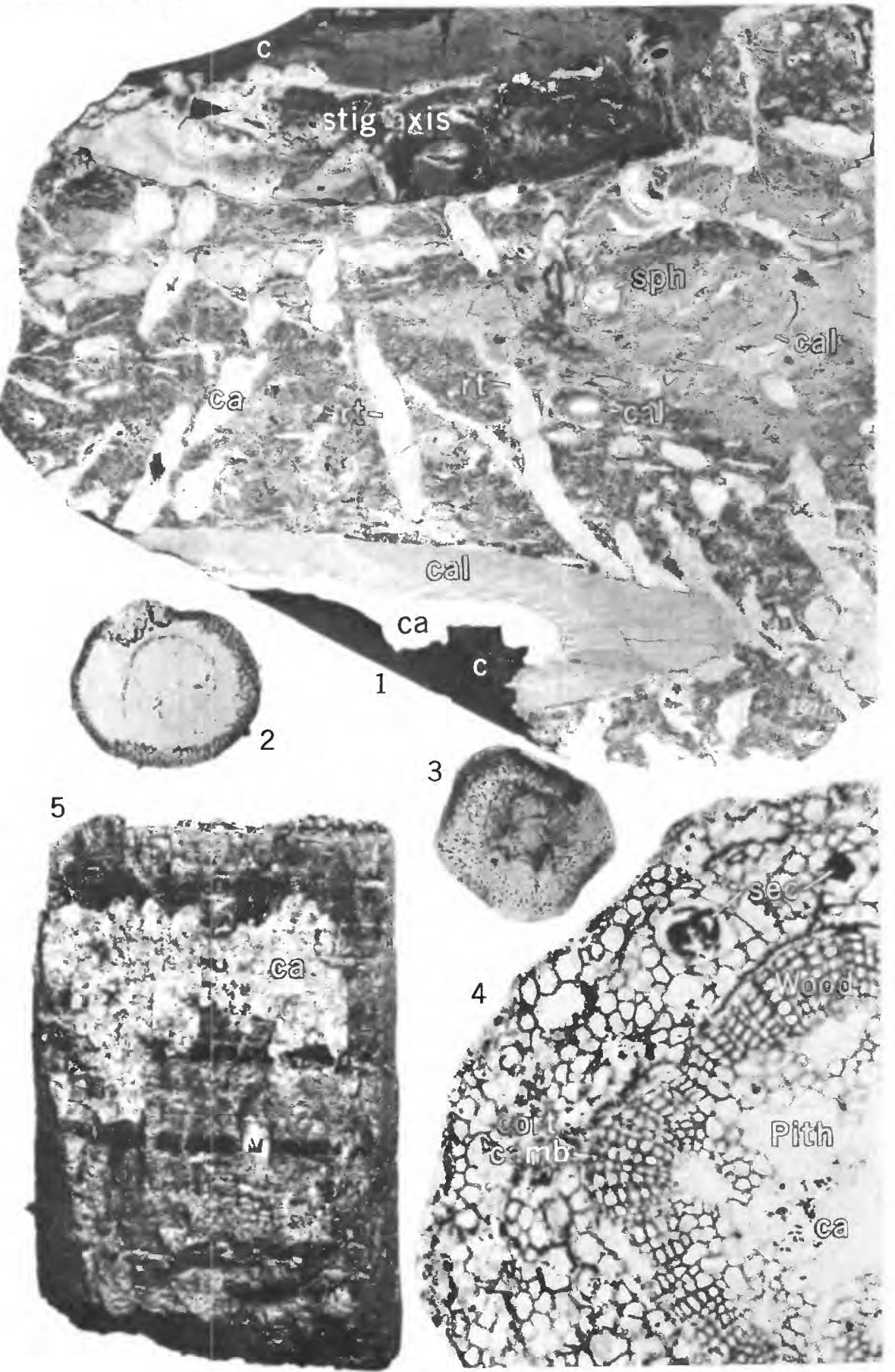

COAL BALLS AND CALCAREOUS IMPURITY 

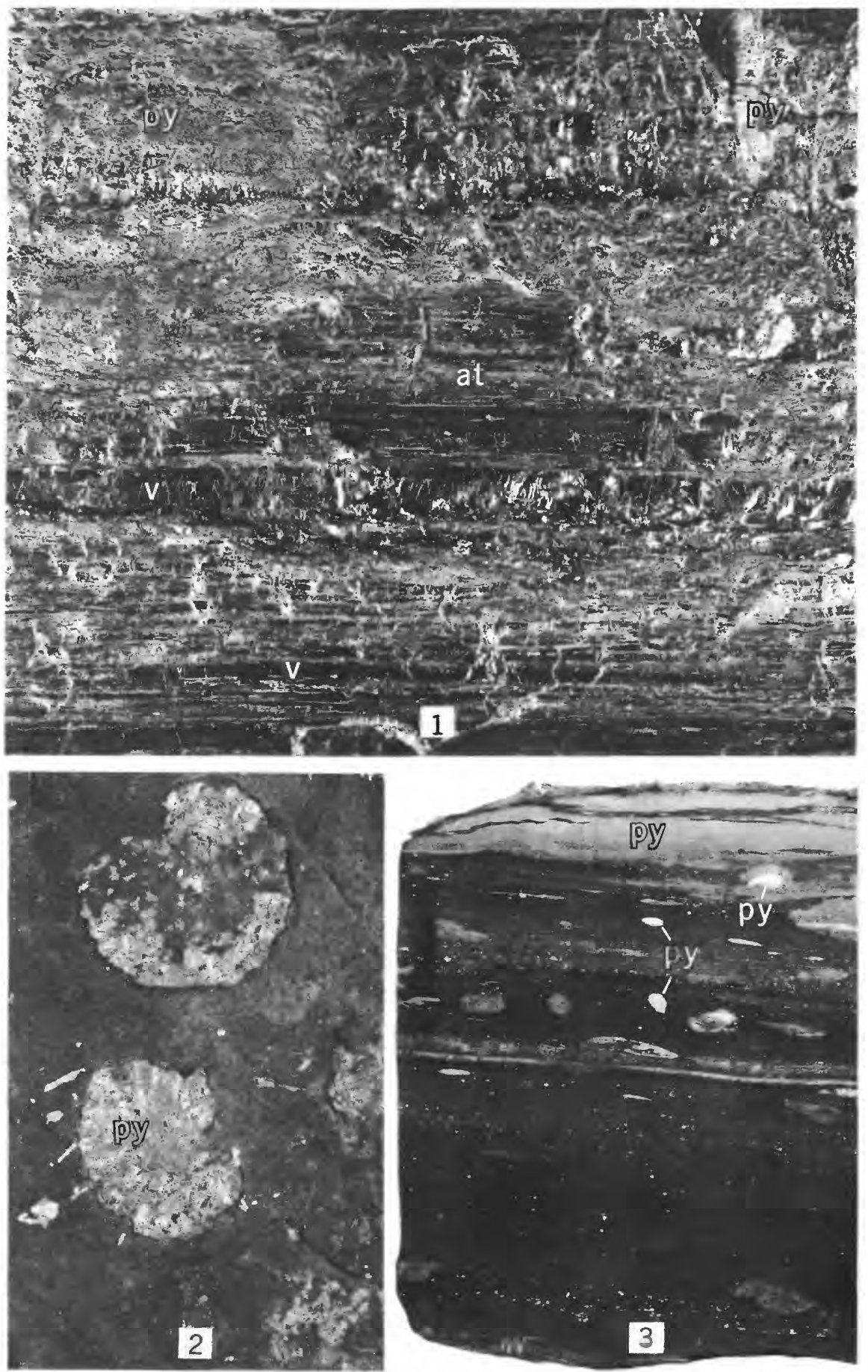

PYRITIC IMPURITY IN COAL AND CARBONACEOUS SHALE 


\section{PLATE 19}

\section{PYRITIC IMPURITY IN COAL AND CARBONACEOUS SHALE}

Figure 1. Spheroidal pyritic aggregation $(p y)$ and pyritic veinlets in top layer of banded bituminous coal, Meigs Creek bed, near Cadiz, Harrison County, Ohio. Photograph at slight enlargement; see also plate 7 , figure 2. The close relation of spheroidal habit and veinlets suggests that this pyrite, in part, was emplaced relatively early at about the time consolidated peat was becoming lignitic. Vitrain $(v)$; attrital coal $(a t)$. Negative $1108, \times 1.37$.

2. Flattened pyritic rosettes $(p y)$ in horizontal bedding surface of carbonaceous roof shale overlying Indiana coal IV, Greene County, Ind. Much disseminated pyrite usually is also present in carbonaceous shales overlying coal beds. Negative $1070, \times 2.00$.

3 . Lenticles and small aggregates of microcrystalline pyrite $(p y)$ in thinbedded carbonaceous Chattanooga shale (Devonian), from near Smithville, De Kalb County, Tenn. These occurrences of pyrite closely resemble those of black sheety shales of the coal measures and in some varieties of impure coal. Negative $1125, \times 1.82$. 


\section{PLATE 20}

\section{ANTHRACITE, NATURAL COKE, AND HIGH RANK BANDED BITUMINOUS COAL}

Figure 1. Polished surface, illuminated at a low angle, slightly enlarged, of highly deformed "shelly" anthracite, from Buck Mountain bed, Pottsville Gap in Sharp Mountain, Schuylkill County, Pa. At this locality, bed is essentially vertical and composed of small prismatic lenticles with slickensided surfaces, equivalent to the elongate diamond-shaped structures cut in the surface photographed. The bed shows some evidence of mass flowage along the myriad of slickensided gliding planes. Specimen shown was held together in part by the contorted zone of mylonitic ( $m y$ ) impurity until it could be embedded in plaster. After cutting and prior to polishing, surface was further impregnated with carnauba wax. Natural plane of banding approximates an angle of $32^{\circ}-35^{\circ}$, parallel to the inclined lower surface at the right, except in the mylonitic areas, and is chiefly determinable from the occurrence of tiny fusain shreds. Evidently the coal is dominantly attrital and thin banded. Luster is bright, as in nearly all anthracite not dulled by weathering or impurity. Negative $1105, \times 2.58$.

2. Outer surface of core of natural coke from deep drill hole, Deep River coal field, near Sanford, Chatham County, N.C. (See Reinemund, 1955.) Negative 1160-1, $\times 1.00$.

3. Smoothed surface of core sliced longitudinally, from deep drill hole, near Sanford, N.C., as in figure 1. Extent of fissuring and minute vesicular texture are shown. Negative 1160-1, $\times 1.00$.

4. Polished surface of specimen of high rank banded bituminous coal, near English Center, Lycoming County, Pa. Surface was inclined to reflect light from vitrain bands (v) and increase the apparent luster contrast with attrital coal. Note that fusain lenticles $(f)$ appear black. Vitrain strongly cleated, attrital coal much less so. Minor slice faulting in the lower part of the block appears to be entirely compensated within the adjacent coal. Negative 1120, $\times$ ca. 1.56 . 


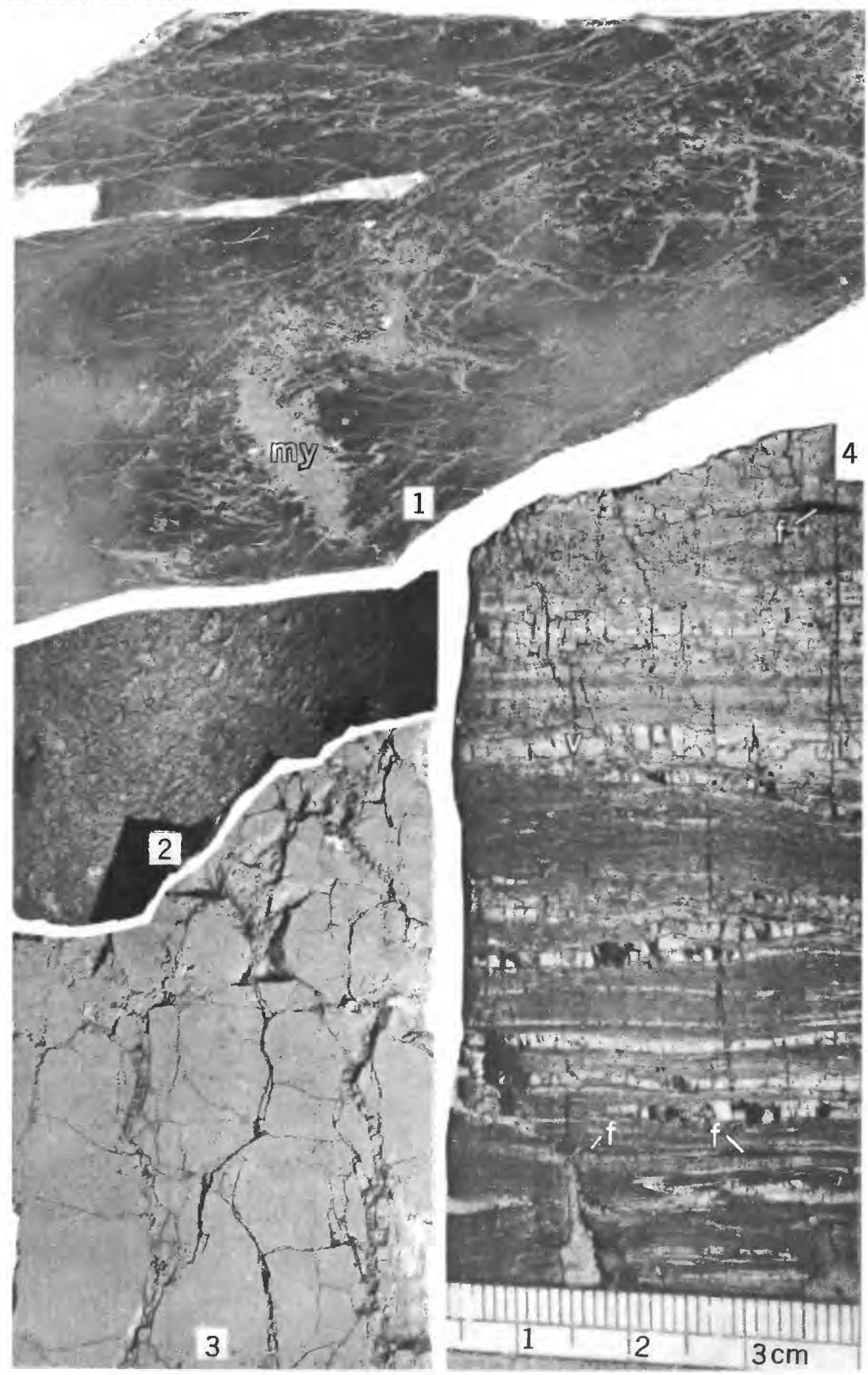

ANTHRACITE, NATURAL COKE, AND HIGH-RANK BANDED BITUMINOUS COAL 

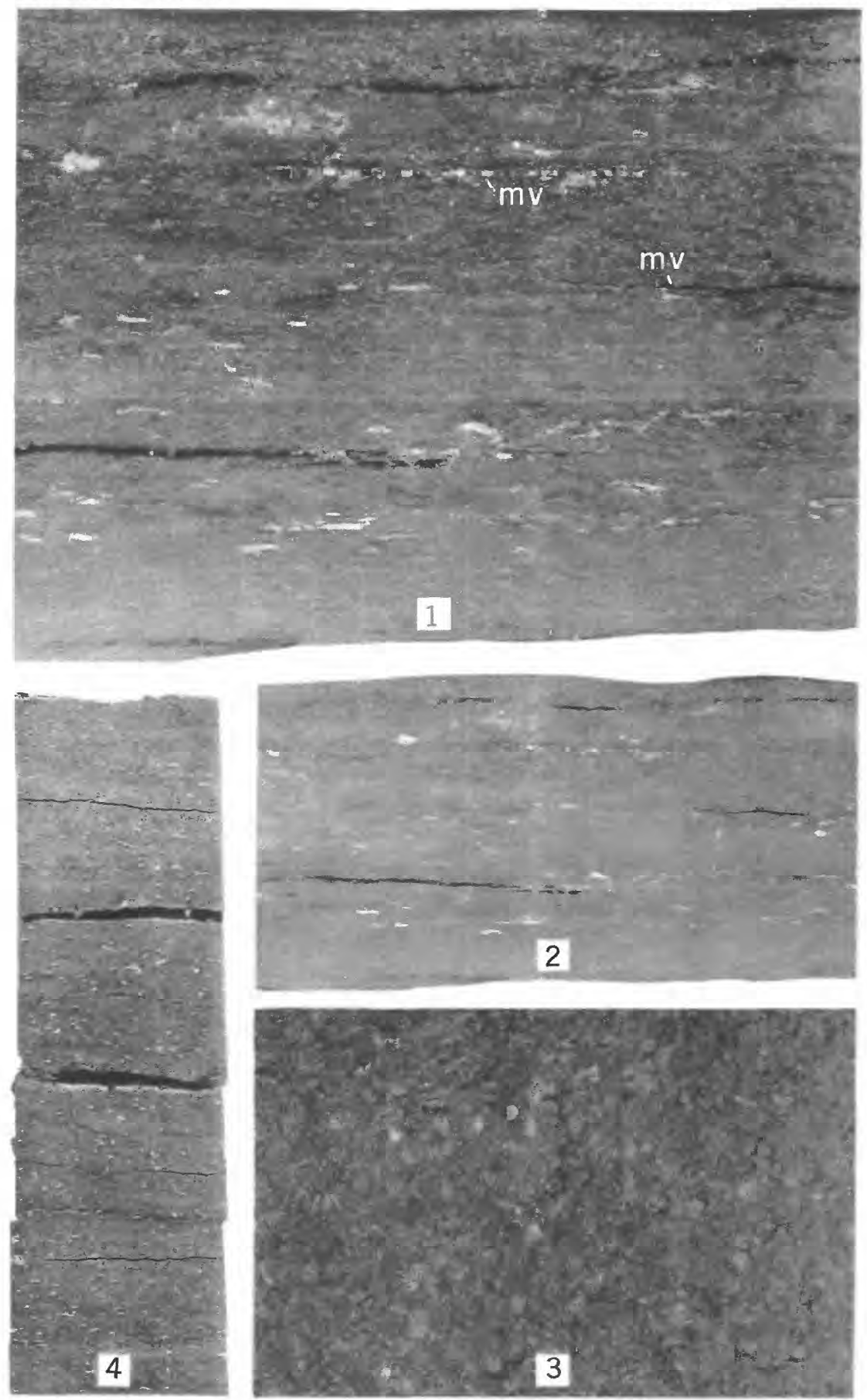

SPORE COAL 


\section{PLATE 21}

\section{SPORE COAL}

Figure 1. Burnished surface normal to bedding, slightly enlarged, of impure, dull luster banded attrital coal, containing numerous lycopsid megaspores, from near Williamston, Ingham County, Mich. (See Bergquist, 1939; Sprunk and others, 1938.) Megaspores show as lighttan flattened elongate bodies and are probably somewhat less abundant in this particular layer than in others. Many smaller spores, 30 to 50 microns diameter, also are present in this coal but they, like other microcomponents, are invisible without microscopic study of carefully prepared sections. Three or four visible streaks of microvitrain $(m v)$ and the large megaspores show that the texture of this coal is heterogeneous and allied with the banded, rather than nonbanded, varieties. Nevertheless, more spore-coat material enters into its composition than in many samples of uniform texture that would be properly classed as cannel. Negative $1117, \times 2.60$.

2. Same surface as in figure 1 , less enlarged and little more than natural size. Negative $1116, \times 1.34$.

3. Horizontal surface of Michigan spore coal in which spore concentration appears greater than on surfaces normal to the bedding. See figures 1 and 2. Concentrations observed from bedding surfaces frequently are deceptive because concentrations differ from top to bottom of bedded laminae and from zones of weakness where spores are most numerous. Negative $1118, \times 2.60$.

4. Attrital lignite layer showing numerous megaspores on smoothed surface of core specimen from the Lower Olesrud bed (Paleocene), southern part of Slim Buttes, Harding County, S. Dak. Spores, light tan, are apparently derived from water ferns (Azolla spp.) and from a species of Isoetes, modern relatives of which are hydrophitic and aquatic. Negative 685 , photograph by R. J. Gray, $\times 1.23$. 
PLATE 22

\section{NONBANDED COAL AND ALLIED TYPES OF CARBONACEOUS ROCKS}

Figure 1. Nonbanded coal about natural size, Middle(?) Kittanning bed, near Putneyville, Armstrong County, Pa. Shows broadly curved conchoidal fracture and satiny luster. In addition, a few small facet cleats ( $f a$; "augen" or "eye" structure) are shown. Microscopic examination indicates absence of boghead algae; so this specimen represents one of the varieties of cannel. Negative $1067, \times 1.05$.

2. Nonbanded coal from same deposit but at a different level from figure 1 , where facet cleating (eye structure) is more in evidence. Surface turned so that the facets are critically illuminated to reflect light to the camera. Orientation of the facets corresponds to that of the major cleat plane in banded coal. Facet cleating in this abundance is very unusual in nonbanded coal. Negative 1071, $\times 1.15$.

3. "Kolm," an attrital highly carbonaceous deposit, noted for its disseminated uranium content, from Upper Cambrian Alum shale of Sweden. Conchoidal fracture is similar to nonbanded coal in figure 1. Although most frequently considered with reference to uranium content and suitability for destructive distillation, microscopic examination suggests this specimen is comparable to moderately impure nonbanded coal. Negative 1077, $\times 1.68$.

4. Horizontal fracture surface Broxburn oil shale, Edinburgh district, Scotland. Specimen shows characteristic slickenside $(s l)$ and irregular fracture.

5. Vertical smoothed surface of Broxburn oil shale similar to that shown in figure 4. Surface etched in hydrofluoric acid to bring out variation in mineral content and relatively indistinct bedding. Cracks indicate the minor influence of bedding on fracture. Microscopic examination shows much more mineral matter than in "kolm" and that organic substances are most comparable to humic degradation matter in coal. Both figures 4 and 5, negative 1124, $\times 1.11$.

6. Thin-bedded Chattanooga shale from core near Smithville, De Kalb County, Tenn. See also plate 19, figure 3. Bedding contrasts strongly with that of Broxburn shale, "kolm," and nonbanded coal, but microscopic examination shows that the type of attrital humic material present in all three is closely comparable. Negative 1125, $\times 1.80$. 

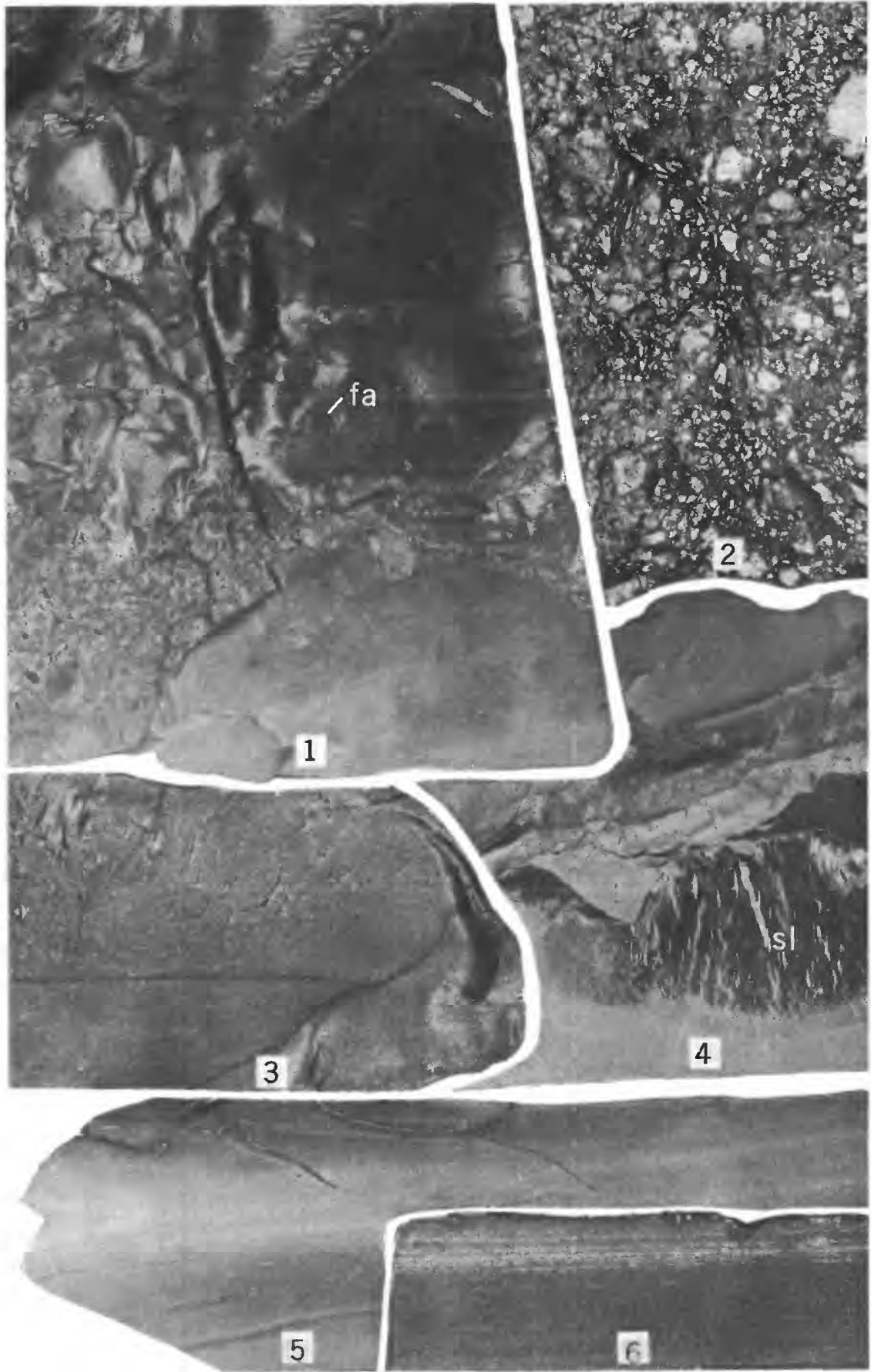

NONBANDED COAL AND ALLIED TYPES OF CARBONACEOUS ROCKS 

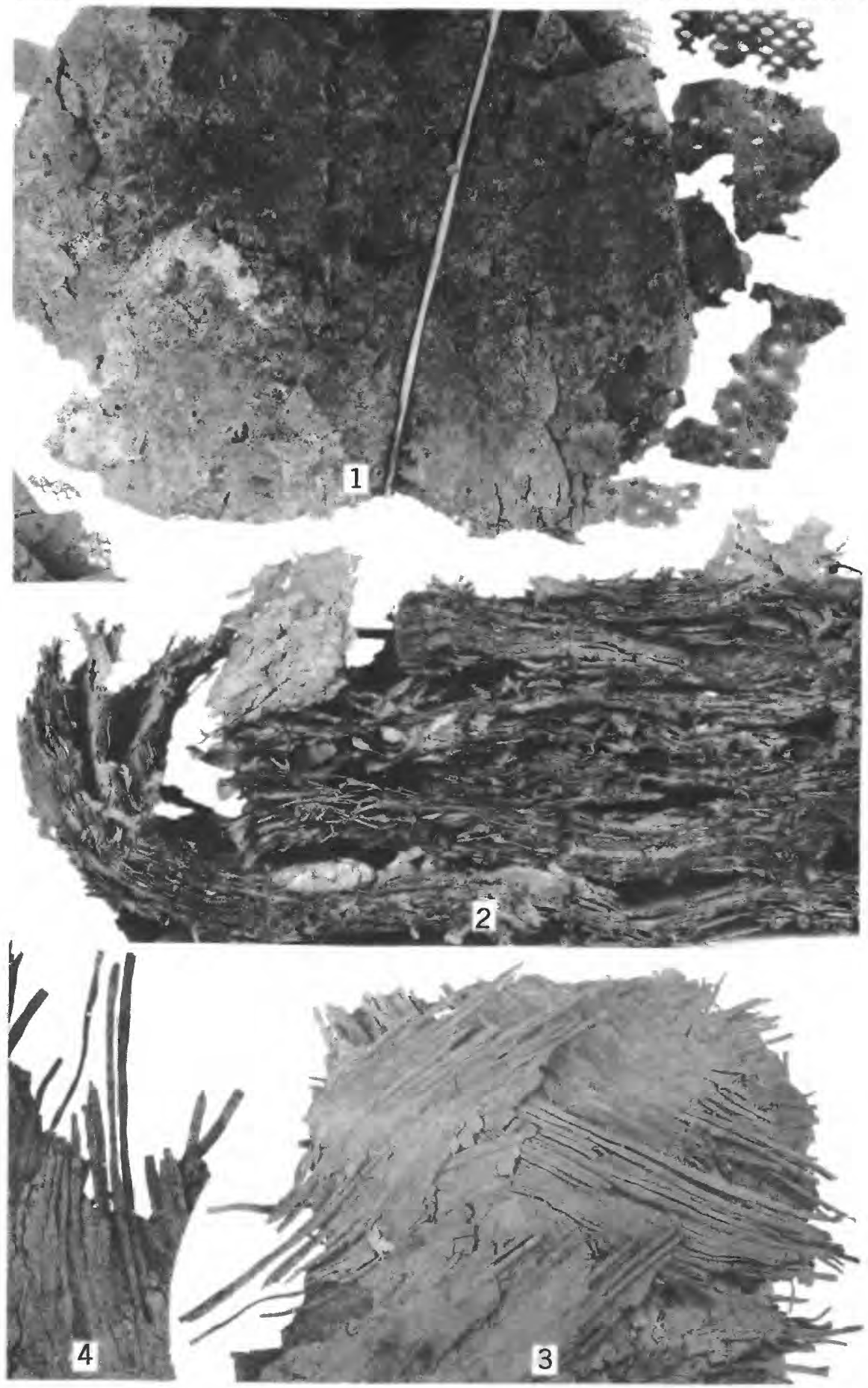

WEATHERING EFFECTS 


\section{PLATE 23}

\section{WEATHERING EFFECTS}

Figure 1. Specimen of the celebrated leaf coal (Lower Carboniferous) from vicinity of Tula, southern part of Moscow basin, U.S.S.R. Specimen obtained from abroad by $\mathrm{G}$. Thiessen. Material is composed almost entirely of cuticles from twigs of Porodendron Nathorst emendatus Bode (cf. Bode, 1929). Perforations represent leaf scars which differ in spacing according to stage of development. Leaf coal has been interpreted as equivalent to lignite in rank, but it probably originates as a result of slow differential leaching of weathered humic substances from medium-rank (bituminous) coal, rich in cuticle. Chemical analyses of such a weathered residuum might easily resemble lignite in oxygen, moisture, and volatile content. Negative $1166 \mathrm{~b}, \times 0.97$.

2. Paper coal from Parke County, Ind. Specimen donated by R. C. Neavel, Coal Division of Indiana Geological Survey, who discovered the occurrence March 1958. Cuticles composing the deposit differ botanically from those composing the Russian deposit of figure 1, but, like it, they seem to be approximately of the same kind. A flake of cuticle is shown impaled on a spearpoint needle as an indication of its physical character. Negative $1165 \mathrm{~b}, \times 1.22$.

3. Pine-needle coal from near Cambria, Weston County, Wyo. Specimen transmitted by J. R. Gill of the U.S. Geological Survey. (See Stone, 1912.) The resinous contents of secretory elements evidently resist oxidation and disintegration much more than humic substances in this coal. Resinous needles that persist on the weathered surfaces are about the size of small pine needles, giving rise to the popular name. Negative $1164 a, \times 1.10$.

4. Resin needles from specimen in figure 3 , at slightly greater enlargement. Negative 1115, $\times 1.55$. 


\section{PLATE 24}

\section{COAL (?)}

FIgure 1. Precambrian coal, collected in 1955 by Kenneth Wier, of the U.S. Geological Survey, from Michigamme formation near Iron Mountain, Iron County, Mich. (See Tyler, and others, 1957.) Structure is characteristically brecciated, in this respect similar to metaanthracite of Narragansett coal field, Rhode Island. Breccia particles are, however, nonbanded and differ in this respect from the Narragansett coal formed normally from higher plants during the Carboniferous period. This is consistent with Barghoorn's suggestion that the Precambrian coal may have formed from microscopic filamentous plants. Negative 1119, $\times 1.32$.

2. "Albert coal" or Albertite, a vein deposit cutting beds of Carboniferous age in Albert County, New Brunswick, Canada. A remarkable conchoidal fracture, more pronounced than in vitrain or in nonbanded coal and resembling that of gilsonite, is shown. Microscopic examination shows no evidence of plant structure, and its solubility characteristics further indicate that this material has no relation to coal. Negative $1076, \times 1.05$. 

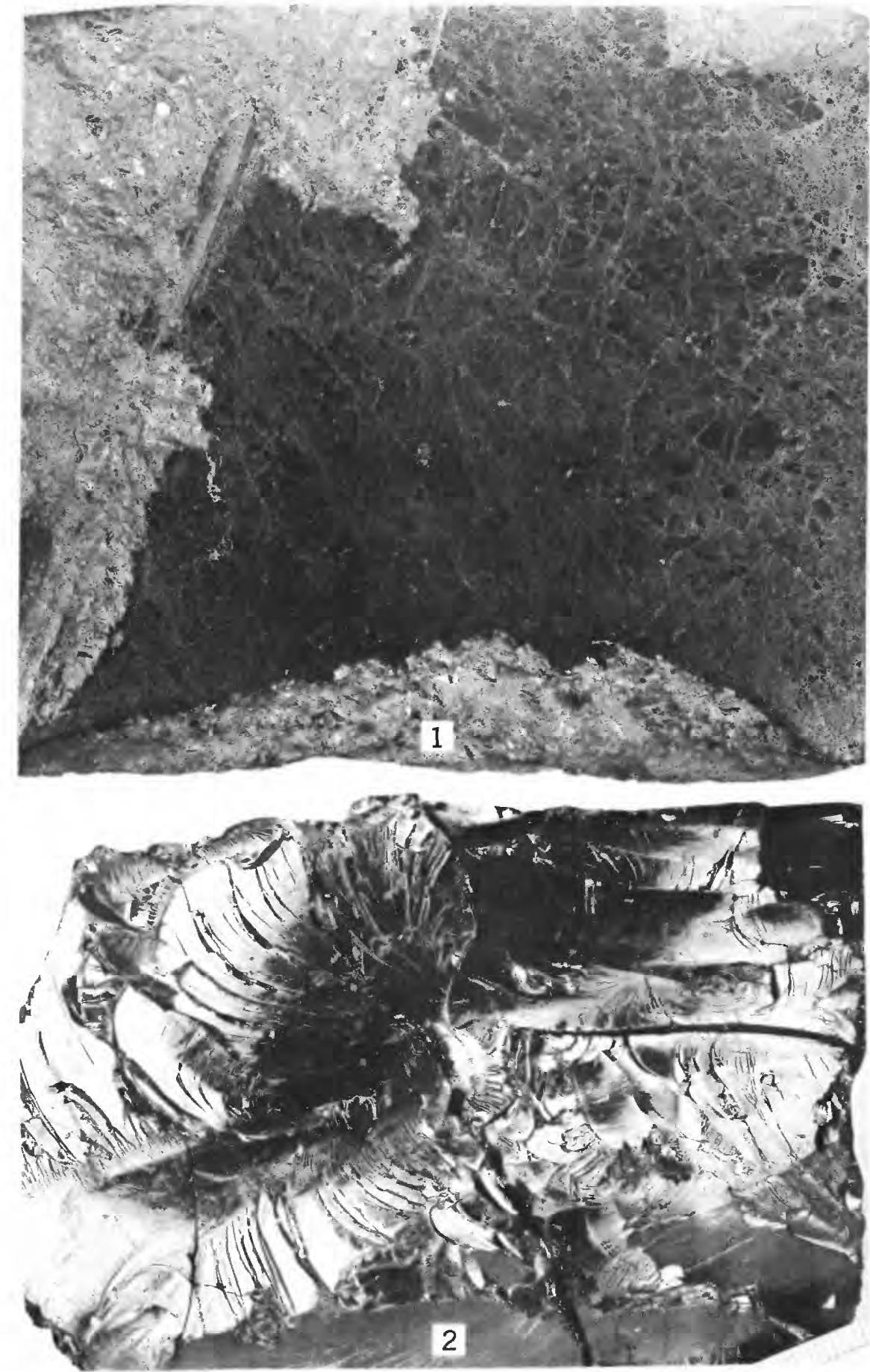

COAL (?) 
